\author{
UNIVERSIDADE DE BRASÍLIA \\ FACULDADE DE CIÊNCIAS DA SAÚDE \\ PROGRAMA DE PÓS-GRADUAÇÃO EM CIÊNCIAS DA SAÚDE
}

FERNANDA DE OLIVEIRA LARANJEIRA

AVALIAÇÃO DAS TECNOLOGIAS DISPONÍVEIS PARA DIABETES TIPO 1 NO BRASIL: EFETIVIDADE, IMPACTO ORÇAMENTÁRIO E CUSTO-EFETIVIDADE

Tese apresentada como requisito parcial para a obtenção do título de Doutora em Ciências da Saúde pelo Programa de Pós-Graduação em Ciências da Saúde da Universidade de Brasília.

Orientador: Prof. Dr. Maurício Gomes Pereira Coorientador: Prof. Dr. Everton Nunes da Silva

BRASÍLIA 


\title{
AVALIAÇÃO DAS TERAPIAS DISPONÍVEIS PARA DIABETES TIPO 1 NO BRASIL: EFETIVIDADE, IMPACTO ORÇAMENTÁRIO E CUSTO-EFETIVIDADE
}

Tese apresentada como requisito parcial para a obtenção do título de doutora em Ciências da Saúde pelo Programa de Pós-Graduação em Ciências da Saúde da Universidade de Brasília.

Aprovado em 21 de fevereiro de 2017

\author{
BANCA EXAMINADORA \\ Maurício Gomes Pereira - Presidente \\ Universidade de Brasília \\ Marcelo Cunio Machado Fonseca \\ Universidade do Estado de São Paulo
}

Luciana Ansaneli Naves

Universidade de Brasília

Jorge Otávio Maia Barreto

Fundação Oswaldo Cruz

Ivan Ricardo Zimmermann

Ministério da Saúde

Flávia Tavares Silva Elias

Fundação Oswaldo Cruz 
Dedico este trabalho a todas as pessoas com diabetes tipo 1 no Brasil e no mundo, que, assim como eu, decidiram vencer mesmo com a doença em suas vidas. 


\section{AGRADECIMENTOS}

Ao Senhor Deus, que é REI DE TODAS AS COISAS. Sem ti eu não sou nada. Minha vida, minha família e esta tese são para sua honra e glória.

À minha família: meu marido, Omar Til Júnior, e meus filhos, João Guilherme de Oliveira Dargélio Til e Sofia de Oliveira Til (nascida durante esse doutorado), pela total parceria, sorrisos, abraços, beijinhos e compreensão pela minha ausência forçada ao longo desses 3,5 anos. Vocês são os amores da minha vida e minha fonte de inspiração.

À minha mãe, Luci Castro de Oliveira Rodrigues, que sempre esteve ao meu lado nos momentos mais difíceis. Obrigada por tudo o que você me ensinou. Te amo!

Ao grupo "Família de Docinhos", pela motivação de vencer e superar todos os obstáculos, tendo o diabetes tipo 1 em suas vidas.

Aos meus chefes e amigos, Marcelo Cunio Machado Fonseca e Gabriela Tannus. Obrigada pelo apoio, compreensão e confiança.

Às amigas que me ajudaram neste trabalho: Keitty Regina Cordeiro de Andrade e Ana Cláudia M. Godoy Figueiredo. Obrigada pela ajuda, força, exemplo e estímulo. Vocês são e sempre serão pesquisadoras excepcionais!

A todos os companheiros do Laboratório de Saúde Baseada em Evidências e Comunicação Científica, pela convivência, amizade e contínua disponibilidade em ajudar.

Às minhas melhores amigas, Erika, Priscila, Flávia, Valdete, Marcela, Mariama e Sandra, pela amizade cultivada ao longo de tantos anos, parceira completa, trabalho em equipe, complementariedade de espírito, e por cuidarem de mim desde o primeiro dia em que nos conhecemos. Nossa amizade é para sempre!

Aos membros da banca, por todas as belíssimas sugestões e críticas, as quais foram muito úteis na construção desta tese e dos artigos científicos posteriores.

A Everton Nunes da Silva, mais que meu coorientador, meu parceiro durante este trabalho. Este estudo é nosso!

Ao meu orientador, Prof. Maurício Gomes Pereira, por ter aceitado o desafio de me orientar. 
"Um pouco de Ciência nos afasta de Deus. Muito, nos aproxima".

(Louis Pasteur) 


\section{RESUMO}

Introdução: Diabetes tipo 1 (DM1) é uma condição crônica, com início geralmente na infância, que pode ser tratada com associação de diferentes tipos de insulina. Das alternativas existentes no mercado brasileiro, apenas as insulinas humanas e as insulinas análogas de ação rápida estão disponíveis para a população pelo Sistema Único de Saúde (SUS) em nível nacional. No entanto, a maioria da população com DM1 ainda não tem acesso às insulinas análogas de longa duração (IALD) e à bomba de insulina. Excesso de estudos sobre o tema provoca recomendações divergentes e, em se tratando de tecnologias de alto custo, causa desconforto entre tomadores de decisão. Objetivo: Avaliar a eficácia das IALD, estimar o impacto orçamentário da incorporação destas no SUS, e calcular a razão incremental de custo-utilidade das alternativas para tratamento do DM1 no Brasil em comparação às insulinas humanas. Método: Este estudo compreendeu três etapas: 1 . Realizamos overview de revisões sistemáticas de ensaios clínicos randomizados (ECRs) sobre eficácia das IALD, assim como atualização das revisões localizadas, por meio de metanálise de ECRs, analisando hemoglobina glicada (A1C) e hipoglicemia. 2. Realizamos análise de impacto orçamentário em horizonte de cinco anos. Utilizamos dados epidemiológicos para projeção da população elegível. Calculamos o poder de barganha do Ministério da Saúde e o aplicamos no preço das insulinas. Realizamos análise de sensibilidade univariada. 3. Conduzimos análise de custo-utilidade, utilizando modelo de Markov para simular complicações crônicas do diabetes. O desfecho final foi custo/ano de vida ajustado por qualidade (QALY). O horizonte temporal foi lifetime. Incluíram-se custos diretos médicos cobertos pelo SUS. Resultados: 1. Localizamos 11 revisões sistemáticas relevantes, contendo um total de 25 ECRs adequados, aos quais adicionamos três advindos de busca complementar. As IALD produziram redução estatisticamente significativa de $0,17 \%$ (IC95\% -0,23; -0,12) na diferença média da A1C em comparação com a insulina NPH. Essa diferença não foi clinicamente significativa. Para hipoglicemias geral e noturna os resultados favoreceram as IALD com redução do risco relativo de $5 \%$ e $34 \%$, respectivamente. Já para hipoglicemia grave, as IALD não apresentaram resultados estatisticamente significativos. 2. O impacto orçamentário incremental das IALD foi $\mathrm{R} \$ 114,3$ milhões no primeiro ano, atingindo 
$\mathrm{R} \$ 235$ milhões no quinto ano. O impacto orçamentário incremental total foi $R \$ 871,4$ milhões em cinco anos. 3. A razão incremental de custo-efetividade da associação entre insulinas análogas foi $R \$ 106$ mil, próxima ao limiar atualmente proposto para países em desenvolvimento. A bomba de insulina provê o maior ganho em QALY, porém este não foi suficiente para compensar seu custo incremental. Conclusão: Produzimos, até onde sabemos, a primeira overview de revisões sistemáticas sobre IALD. Este delineamento permitiu realizar avaliação abrangente sobre o tema, preenchendo lacuna nas pesquisas em diabetes, uma vez que existe sobreposição de estudos com recomendações contraditórias. Com relação ao impacto orçamentário, a principal vantagem deste estudo foi o poder de barganha para produzir estimativas mais realistas de uso de recursos, uma vez que a compra centralizada é estratégia economicamente sustentável. A estratégia mais interessante apontada pelos três estudos é a associação entre insulinas análogas de longa duração e ação rápida.

Palavras-chave: diabetes tipo 1; avaliação de tecnologias em saúde; overview; revisão sistemática; impacto orçamentário; custo-utilidade; economia da saúde. 
Introduction: Type 1 diabetes (T1D) is a chronic condition, usually beginning in childhood. It can be treated with an association of different types of insulin. Among the alternatives available in the Brazilian market, only human insulins and rapidacting insulin analogues are available to the population by the National Public Health System (SUS) at the national level. However, T1D population still cannot access long-acting insulin analogues (LAIA) and insulin pumps by SUS. The excess of published studies on the subject cause divergent recommendations and, in the case of high-cost technologies, cause discomfort among decision makers. Objective: To evaluate the effectiveness of LAIA, to estimate the budget impact of the coverage of these insulins by SUS, and to calculate the incremental cost- effectiveness ratio of the treatment alternatives for T1D in Brazil compared to human insulin. Method: This study comprised three steps. 1. We performed overview of systematic reviews on the efficacy of LAIA, as well as updated existing reviews by meta-analysis of randomized controlled trials (RCTs), analyzing glycated hemoglobin (A1C) and hypoglycemia. 2. We performed budget impact analysis over a five-year horizon. We used epidemiological data for the projection of the eligible population. We calculate the bargaining power of the Ministry of Health and apply it to the price of insulins. Univariate sensitivity analyzes was performed. 3 . We conducted a cost-utility analysis using a Markov model to simulate chronic complications of diabetes. Primary outcome was cost/ quality adjusted life year (QALY). The time horizon was lifetime. Direct medical costs covered by SUS were included. Results: 1. We located 11 relevant systematic reviews, contained a total of 25 adequate RCTs, to which we added three coming from complementary search. LAIA produced a statistically significant reduction of $0.17 \%(95 \% \mathrm{Cl}-0.23 ;-0.12)$ in the $\mathrm{A} 1 \mathrm{C}$ mean difference compared to NPH insulin. This difference was not clinically significant. For general and nocturnal hypoglycemia, the results favored LAIA with relative risk reduction of $5 \%$ and $34 \%$, respectively. For severe hypoglycemia, analogue insulins did not present statistically significant results. 2 . The incremental budget impact of LAIA was $\mathrm{R} \$ 114.3$ million in the first year, reaching $\mathrm{R} \$ 235$ million in the fifth year. Total incremental budget impact was $\mathrm{R} \$ 871.4$ million over five years. 3 . The incremental cost-effectiveness ratio of the association between analogue insulins was $R \$ 106$ 
thousand, close to the threshold currently proposed for developing countries. The insulin pump provided the highest gain in QALY, but this was not enough to overpass its incremental cost. Conclusion: We produced, as far as we know, the first overview of systematic reviews on LAIA. This design allowed us to carry out a more comprehensive evaluation on the subject, filling a gap in diabetes research, since there is a lot of overlapping studies with contradictory recommendations. Regarding the budget impact, the main advantage of this study was the application of bargaining power to produce more realistic estimates of resource use, since centralized purchasing is an economically sustainable strategy. The most interesting strategy pointed out by the three studies is the association between long-acting and rapidacting insulin analogues.

Keywords: type 1 diabetes; health technology assessment; overview; systematic review; budget impact; cost-utility; health economics. 


\section{LISTA DE FIGURAS}

Figure 2.1 Flowchart of the study selection process for systematic reviews

Figure 2.2 Risk of bias on included randomized clinical trials

Figure 2.3 Meta-analysis of glycated hemoglobin

Figure 2.4 Meta-analysis of general hypoglycaemia

Figure 2.5 Meta-analysis of severe hypoglycaemia

Figure 2.6 Meta-analysis of nocturnal hypoglycaemia 36

Figure 2.7 Publication bias analysis by Begg's funnel plots 38

Figure 3.1 Model population dynamics for the budget impact analysis. $\quad 60$

Figure 3.2 Variation of incremental budget impact according to changes on 62 the assumptions of the model

Figure 3.3 Budget impact evolution due to variation of insulin analogues price 63

Figura 4.1 Representação do modelo de custo-utilidade utilizado 78

Figura 4.2 Gráfico da análise de custo-efetividade $\quad 87$

Figura 4.3 Diagrama de Tornado, mostrando as variáveis do modelo e a 89 influência de cada uma na incerteza do resultado 


\section{LISTA DE TABELAS}

Table 2.1 - Distribution of considered clinical trials among included systematic reviews

Table 2.2 - The AMSTAR score of included systematic reviews

Table 3.1 - Average daily dose used per age group 58

Table 3.2 - Budget impact by scenario and incremental cost by year and for 561 years period (in $R \$ 1,000$ )

Tabela 4.1 - Probabilidades de transição entre os estados do Modelo de Markov

Tabela 4.2 - Custos utilizados no modelo e fontes de informação

Tabela 4.3 - Dose média (desvio padrão) das intervenções avaliadas

Tabela 4.4 - Medidas de efetividade das intervenções comparadas 84

Tabela 4.5 - Aplicação da redução percentual de A1C no risco de desenvolvimento de complicações

Tabela 4.6 - Utilidades das complicações crônicas microvasculares do diabetes tipo 1 , segundo dois modelos pré-estabelecidos

Tabela 4.7 - Razão incremental de custo-efetividade das alternativas terapêuticas estudadas 


\section{LISTA DE ABREVIATURAS E SIGLAS}

A1C: Hemoglobina glicada

CID-10: Classificação Internacional de Doenças

CONITEC: Comissão Nacional de Incorporação de Tecnologias no Sistema Único de Saúde

DATASUS: Departamento de Informática do Sistema Único de Saúde

DOU: Diário Oficial da União

DM1: Diabetes mellitus tipo 1

ECRs: Ensaios clínicos randomizados

MD: Mean difference

NPH: Neutral Protamine Hagedorn

OR: Odds Ratio

RCTs: Randomized controlled trials

RR: Relative Risk ou Risco Relativo

SIA-SUS: Sistema de Informações Ambulatoriais do Sistema Único de Saúde

SIGTAP: Sistema de Gerenciamento da Tabela de Procedimentos, Medicamentos e Órteses, Próteses e Materiais Especiais do Sistema Único de Saúde

SIH-SUS: Sistema de Informações Hospitalares do Sistema Único de Saúde

SUS: Sistema Único de Saúde

T1D: Type 1 diabetes 


\section{SUMÁRIO}

1 INTRODUÇÃO

2 INSULINAS ANÁLOGAS DE LONGA DURAÇÃO PARA DIABETES TIPO 1: OVERVIEW DE REVISÕES SISTEMÁtICAS E METANÁLISE DE ENSAIOS CLÍNICOS RANDOMIZADOS 20

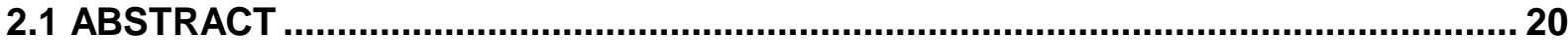

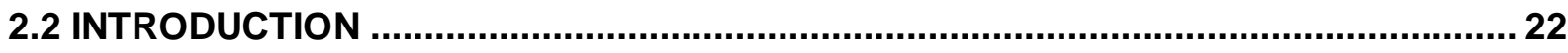

2.3 METHODS.

2.3.1 Design and Register ..................................................................................... 23

2.3.2 Criteria for Considering Reviews for Inclusion ................................................ 23

2.3.3 Search Methods for Identification of Studies....................................................... 24

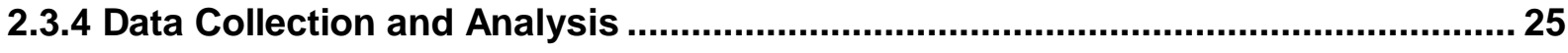

2.3.5 Data Extraction and Management .......................................................................... 26

2.3.6 Assessment of Methodological Quality of Included Reviews ................................ 27

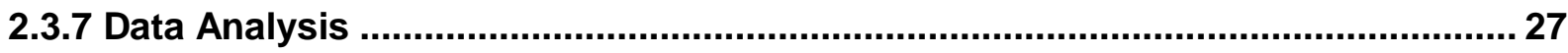

2.4 RESULTS

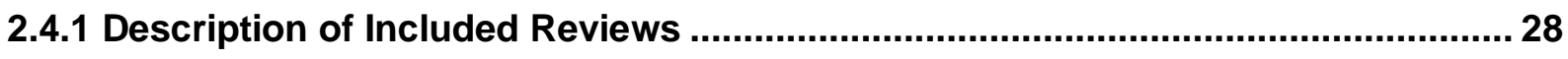

2.4.2 Methodological Quality of Included Studies ........................................................... 31

2.4.2.1 Quality of Included Reviews ............................................................................. 31

2.4.2.2 Quality of Evidence in Included Reviews ....................................................... 32

2.4.3 Quantitative Analysis............................................................................................ 33

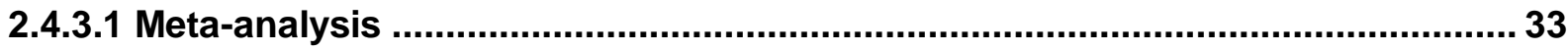

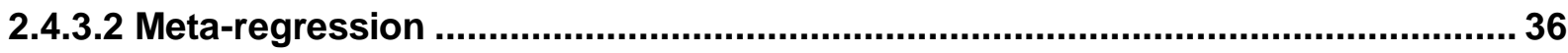

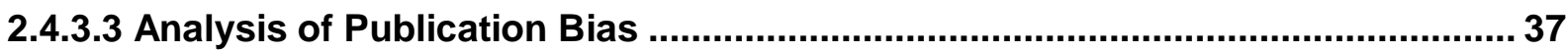

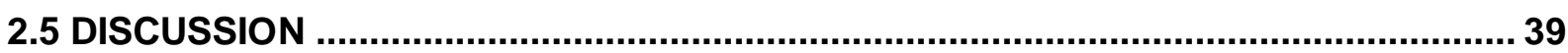

3 IMPACTO ORÇAMENTÁRIO DAS INSULINAS ANÁLOGAS DE LONGA DURAÇÃO: O

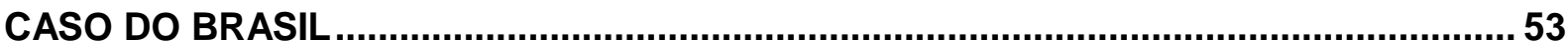

3.1 ABSTRACT

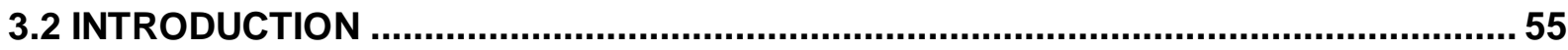

3.3 METHODS.

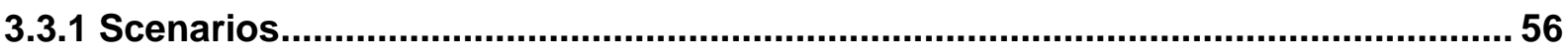

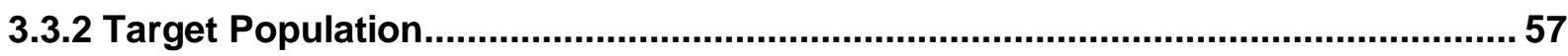

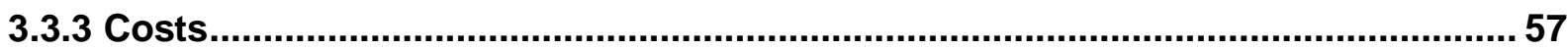




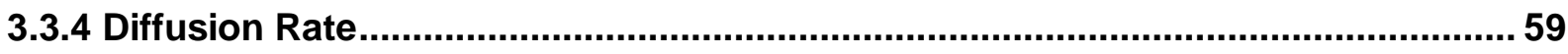

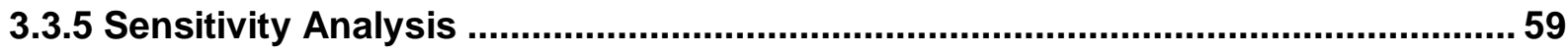

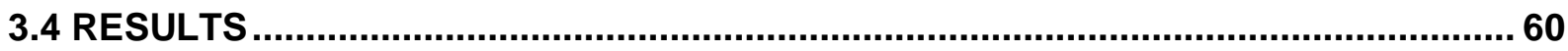

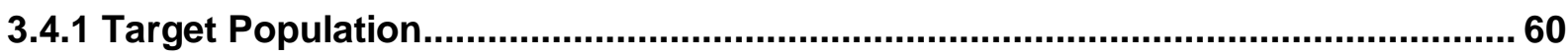

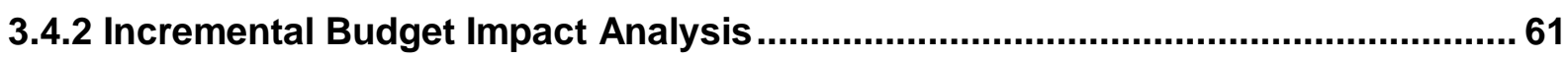

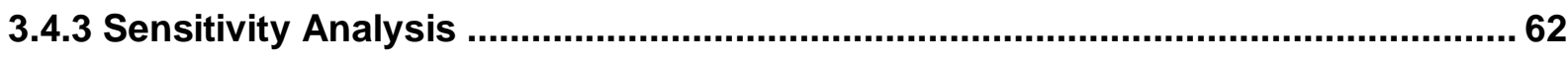

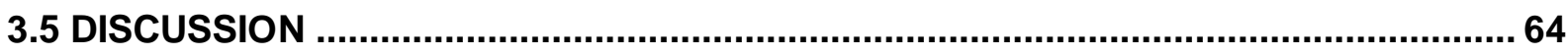

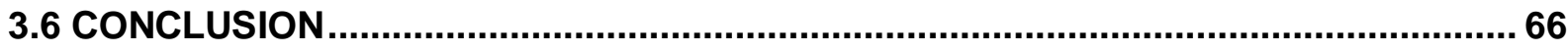

4 CUSTO-EFETIVIDADE DAS TERAPIAS DISPONÍVEIS PARA DIABETES TIPO 1 NO BRASIL: PERSPECTIVA DO SISTEMA ÚNICO DE SAÚDE ......................................... 74

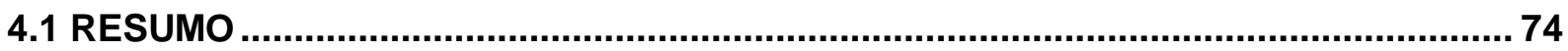

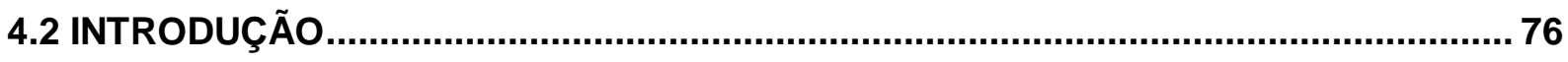

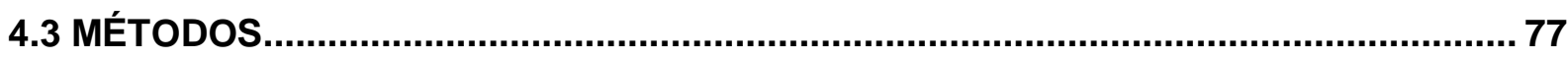

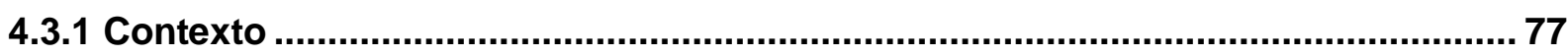

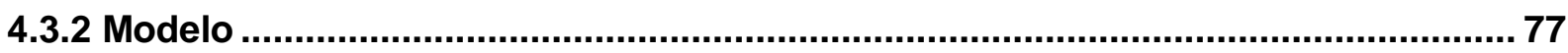

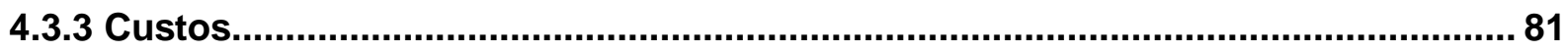

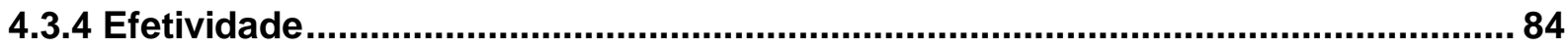

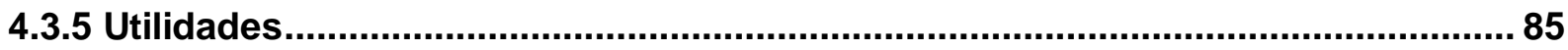

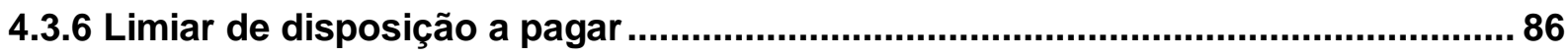

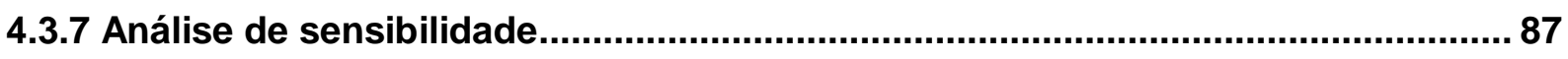

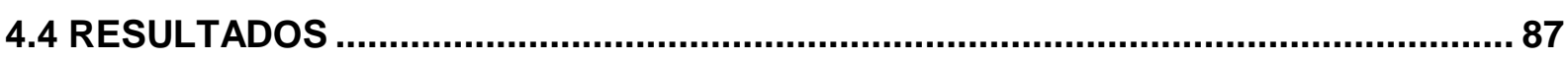

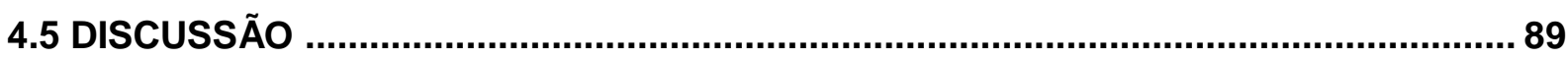

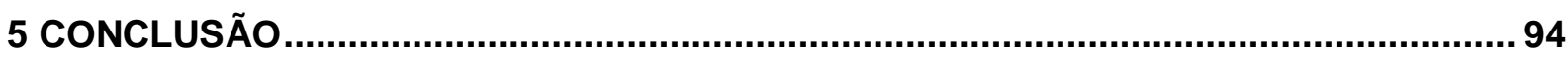

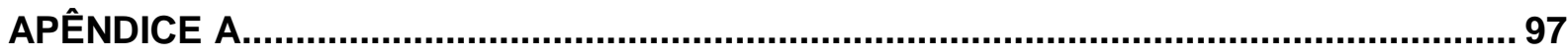

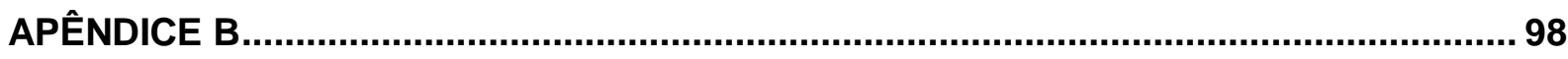

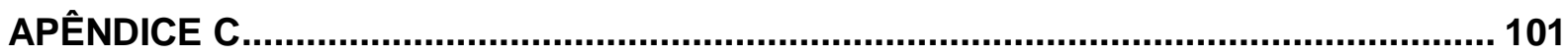

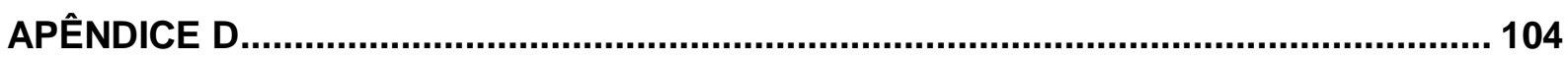

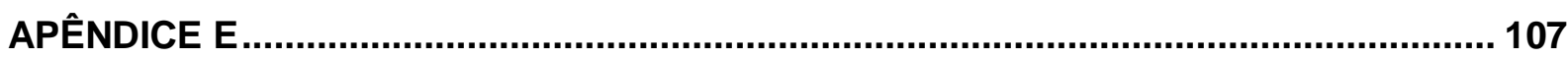




\section{INTRODUÇÃO}

O diabetes mellitus tipo 1 (DM1) é uma condição de saúde de alto impacto para os sistemas de saúde. Isso não se deve somente ao fato de ser uma doença crônica, com início geralmente na infância, que afeta pessoas economicamente ativas, e de alto impacto pessoal e social. Deve-se também aos gastos crescentes, envolvendo a terapia e as novas tecnologias a ela relacionadas e, principalmente, as diversas complicações crônicas associadas $(1,2)$.

Estima-se que 6,2\% da população brasileira acima de 18 anos sejam portadores de diabetes $(3,4)$. Do total de casos, $5 \%$ a $10 \%$ possuem o tipo 1 da doença (5) e, portanto, totalmente dependentes de insulina exógena.

O objetivo do tratamento dos pacientes com DM1 é manter um controle glicêmico adequado e evitar as complicações decorrentes da doença (6). O diabetes mal controlado favorece a incidência de complicações crônicas micro e macrovasculares, que incluem: neuropatia, maior causa de amputação não traumática de membros inferiores (2); nefropatia, causa de $62 \%$ das insuficiências renais crônicas do país, incluindo terapia renal substitutiva (transplantes e diálises) (7); retinopatia, maior causa de cegueira no Brasil (7); doenças cardiovasculares e acidentes vasculares encefálicos, representando um risco duas a quatro vezes maior de ocorrência de tais eventos (7). Além disso, segundo a Organização Mundial de Saúde (8), após 15 anos de doença, 2\% dos diabéticos estarão cegos, 30 a 45\% terão retinopatia em algum grau, 10 a $20 \%$ terão nefropatia, 20 a 35\% neuropatia, e 10 a $25 \%$ deles terão desenvolvido algum tipo de doença cardiovascular. Sabe-se também que a expectativa de vida de um diabético tipo 1 é reduzida em média em 15 anos (7).

Nesse sentido, o maior ensaio clínico em DM1 de todos os tempos $(9,10)$, o qual comparou o controle intensivo (mais de três injeções por dia ou bomba de insulina) e o controle convencional (menos de três injeções por dia, visando evitar sintomas), seguiu os pacientes por 6,5 anos em média. Seus autores concluíram que o controle intensivo reduziu em $76 \%$ o risco de desenvolver retinopatia (IC95\% $62-85 \%$ ), em $54 \%$ o de nefropatia (IC95\% 19-74\%) e em $60 \%$ o de desenvolver neuropatia (IC95\% 38-74\%). Em compensação, o grupo do tratamento intensivo esteve relacionado a um risco três vezes maior de hipoglicemia. 
Entre as opções terapêuticas mais utilizadas, identificamos a terapia de múltiplas injeções diárias, com associação entre insulinas com perfis basal e bólus, isto é, de longa e rápida duração, respectivamente. As insulinas basais garantem uma cobertura de ação mais longa, controlando a glicemia resultante da lipólise e da produção hepática de glicose (gliconeogênese). As insulinas tipo bólus têm ação rápida e devem ser aplicadas antes das refeições (de acordo com a quantidade de carboidratos ingeridos) ou como correção em casos de hiperglicemia $(2,6,11)$.

As insulinas basais incluem a insulina humana NPH (Neutral Protamine Hagedorn) e as insulinas análogas à humana de longa-duração, glargina, detemir e degludec. As insulinas tipo bólus incluem a insulina humana regular e as insulinas análogas à humana de ação rápida, lispro, asparte e glulisina $(2,11)$.

Além da terapia de múltiplas injeções diárias, é possível o tratamento do DM1 com a utilização do sistema de infusão contínua de insulina (bomba de insulina), o qual mostra, em alguns estudos, ser o mais eficaz quando comparado às múltiplas injeções (12). Em alguns países desenvolvidos, como Reino Unido (13), Austrália (14) e Canadá (15), a indicação absoluta da bomba de insulina é para crianças com DM1, pois a terapia com injeções pode ser apontada como impraticável ou desapropriada para essa população (13).

No Brasil, a distribuição das insulinas humanas pelo Sistema Único de Saúde (SUS) está regulamentada para todos os diabéticos desde 2006 (16). Já as insulinas análogas de ação rápida foram recém-incorporadas no SUS a nível nacional para crianças com DM1 em 2016 (17). As análogas de longa duração ainda não estão disponíveis em nível nacional, mas apenas em nível estadual e municipal em Unidades da Federação com protocolos estabelecidos, como São Paulo (18), Rio Grande do Sul (19), Bahia (20), Distrito Federal (21), entre outros. Já a bomba de insulina, está disponível gratuitamente apenas no Distrito Federal e na cidade de Goiânia. Nos entes da Federação que disponibilizam análogas e bombas de insulina, esse procedimento está vinculado a protocolos clínicos com indicações específicas, considerando que essas tecnologias, sendo de alto custo, devem ser priorizadas para grupos nos quais apresentem maior efetividade.

A eficácia de todos os tratamentos para DM1 é medida em termos de diminuição na hemoglobina glicada, desfecho laboratorial relacionado ao controle glicêmico e, consequentemente, à diminuição do risco de complicações (22). Além disso, as intervenções em diabetes procuram evidenciar associadamente redução 
no risco de hipoglicemias, posto que esse é o maior desafio relacionado ao controle intensivo, como demonstrado pelo DCCT (9).

Diante de todas as opções terapêuticas, ainda restam dúvidas sobre qual das alternativas disponíveis para tratamento do DM1 é a mais efetiva e custo-efetiva na realidade brasileira. Além disso, internacionalmente, não existem estudos de custoefetividade que comparem todas as opções terapêuticas entre si, incluindo como alternativas as combinações entre os tipos de insulina e as formas de administração.

Nesse sentido, os objetivos deste projeto são:

I. avaliar a eficácia das insulinas análogas de longa duração,

II. estimar o impacto orçamentário da incorporação das insulinas análogas de longa duração no Sistema Único de Saúde, e

III. calcular a relação de custo-efetividade incremental de todas as alternativas terapêuticas para tratamento do DM1 disponíveis no mercado brasileiro em comparação ao caso base, que consiste da combinação de insulinas humanas (NPH e Regular).

O texto da presente tese está estruturado no formato de três artigos científicos, os quais visam a responder aos objetivos elencados, além de uma conclusão única, a qual reúne comentários sobre os três estudos, seus resultados e a resposta aos objetivos traçados inicialmente. 


\section{REFERÊNCIAS}

1. Schmidt MI, Duncan BB, Silva GA, Menezes AM, Monteiro CA, Barreto SM et al. Chronic non-communicable diseases in Brazil: burden and current challenges. Lancet 2011; 377:1949-61.

2. Sociedade Brasileira de Diabetes. Diretrizes da Sociedade Brasileira de Diabetes (2015-2016) / Adolfo Milech [et. al.]; organização José Egidio Paulo de Oliveira, Sérgio Vencio - São Paulo: A.C. Farmacêutica, 2016. Disponível em: http://www.diabetes.org.br/sbdonline/images/docs/DIRETRIZES-SBD-2015-2016.pdf. 3. Laranjeira FO, Brito GV, Tannus G, Fonseca MCM. Target population for innovative technology on diabetes in Brazil: everybody needs to know about prevalence. Association of Technology and Therapeutics for Diabetes Annual Meeting 2017, Book of Abstracts.

4. Iser BP, Stopa SR, Chueiri PS, Szwarcwald CL, Malta DC, Monteiro HO, Duncan BB, Schmidt MI. Prevalência de diabetes autorreferido no Brasil: resultados da Pesquisa Nacional de Saúde 2013. Epidemiologia e Serviços de Saúde. 2015 Jun;24(2):305-14.

4. International Diabetes Federation. IDF Diabetes Atlas. 2015. ISBN: 2-930229-85-

3. Disponível em: http://www.idf.org/diabetesatlas.

5. Laranjeira FO, Silva EN, Pereira MG. Budget Impact of Long-Acting Insulin Analogues: The Case in Brazil. PLoS ONE 2016; 11(12): e0167039. doi:10.1371/journal.pone.0167039.

6. American Diabetes Association. Standards of Medical Care in Diabetes - 2016.

Diabetes Care. January 2016 Jan; 39(S1-S112).

7. Brasil. Ministério da Saúde. Secretaria de Atenção à Saúde. Cadernos de Atenção Básica - Diabetes. Ministério da Saúde, Brasília, 2006.

8. World Health Organization. Technical Report: Definition and diagnosis of diabetes mellitus and impairment glycaemic regulation. Genebra: OMS, 2006.

9. Diabetes Control and Complications Trial Research Group. The Effect of Intensive Treatment of Diabetes on the Development and Progression of Long-Term Complications in Insulin-Dependent Diabetes Mellitus. New England Journal of Medicine, 1993;329(14):977-986. 
10. White $\mathrm{NH}$, et al. Beneficial effects of intensive therapy of diabetes during adolescence: outcomes after the conclusion of the Diabetes Control and Complications Trial (DCCT). J Pediatr. 2001;139(6):804-12.

11. National Institute for Health and Clinical Excellence. Type 1 diabetes: the diagnosis and management of type 1 diabetes in adults. Clinical Guideline \#15, 2004. Update In progress. Disponível em: http://guidance.nice.org.uk/CG/WaveR/122. Acessado em 10/06/2013.

12. Pickup JC, Sutton AJ. Severe hypoglycaemia and glycaemic control in Type 1 diabetes: meta-analysis of multiple daily insulin injections compared with continuous subcutaneous insulin infusion. Diabetic Medicine. 2008 Jul 1;25(7):765-74.

13. National Institute for Health and Clinical Excellence. Technology appraisal guidance 151: Continuous subcutaneous insulin infusion for the treatment of diabetes mellitus. Review of technology appraisal guidance 57. Issue date: July 2008. Review date: February 2011. Disponível em: www.nice.org.uk/TA151.

14. Australian Government. Department of Health. Other Australian Government health technology funding programs: Type 1 Diabetes Insulin Pump Program.

Disponível em: http://www.health.gov.au/internet/hta/publishing.nsf/Content/other1\#Type\%201\%20Diabetes.

15. Canadian Agency for Drugs and Technologies in Health. Rapid Response Report: Continuous Subcutaneous Insulin Infusion for Type 1 Diabetes: Clinical Effectiveness, Cost-Effectiveness, and Guidelines. 6 April 2015. Disponível em: https://www.cadth.ca/continuous-subcutaneous-insulin-infusion-type-1-diabetesclinical-effectiveness-cost-effectiveness.

16. Lei Diabetes 2006

17. Comissão Nacional de Incorporação de Tecnologias no SUS. Insulinas análogas de ação rápida para Diabetes Mellitus Tipo 1: Relatório de Recomendação.

Setembro de 2016. Disponível em: http://conitec.gov.br/images/

Consultas/Relatorios/2016/InsulinasCP25 2016.pdf.

18. Secretaria de Estado da Saúde de São Paulo. Coordenadoria das Regiões de Saúde DIR-XIV-Marília. Protocolo de normatização para a dispensação de análogos de insulina de longa duração (insulina glargina e detemir) e de curta duração (lispro e aspart) na rede pública de saúde. Disponível em:

http://docplayer.com.br/17086450-Secretaria-de-estado-da-saude-coordenadoriadas-regioes-de-saude-dir-xiv-marilia.html. 
19. Secretaria de Estado da Saúde do Rio Grande do Sul. Instituto da Criança com diabetes. Protocolo clínico para dispensação de insumos para pacientes com diabetes mellitus tipo 1 na rede pública de saúde. Disponível em: http://www.icdrs.org.br/arquivos/pdf/Protocolo Insumos ICD.pdf. 20. Diário Oficial do Estado da Bahia. Portaria №. 1603 de 14 de novembro de 2012. Instituir o Protocolo técnico para a dispensação de análogos de insulina de ação basal e ultra-rápida para pacientes com diagnóstico de Diabetes Mellitus. Disponível em: http://www.saude.ba.gov.br/cedeba/pdf/portaria n 160312.pdf.

21. Secretaria de Estado de Saúde do Distrito Federal. Formulário para uso (inclusão) de insulinas análogas: ação prolongada e ultrarrápida da SES/DF. Disponível em:

http://www.saude.df.gov.br/images/Programas/FORMULARIO PARA USO INCLUSAO- DE INSULINAS ANALOGAS DA SES-DF.pdf.

22. U.S. Department of Health and Human Services. Food and Drug Administration. Center for Drug Evaluation and Research (CDER). Guidance for Industry Diabetes Mellitus: Developing Drugs and Therapeutic Biologics for Treatment and Prevention. February 2008. Avalable: http://www.fda.gov/downloads/ Drugs/Guidances/ucm071624.pdf. 


\section{INSULINAS ANÁLOGAS DE LONGA DURAÇÃO PARA DIABETES TIPO 1: OVERVIEW DE REVISÕES SISTEMÁTICAS E METANÁLISE DE ENSAIOS CLÍNICOS RANDOMIZADOS}

\subsection{ABSTRACT}

Background: Diabetes prevalence is growing worldwide, and 5 to $10 \%$ of diabetes patients have type 1 diabetes (T1D). Evidence on the effects of intermediate-acting human insulin and long-acting insulin analogues is extensive. However, the substantial number of clinical trials and systematic reviews published on the issue make divergent recommendations, which is causing discomfort among decision makers.

Objective: To conduct an overview of systematic reviews and update existing reviews, aggregating clinical trials published to date and prepare new meta-analysis to determine whether long-acting insulin analogues are effective and safe for T1D patients compared to NPH in the reduction of hypoglycaemia and maintenance or improvement of glycemic control.

Data Sources: We identified systematic reviews of randomized controlled trials (RCTs) with any publication date that evaluated the efficacy of long-acting insulin analogues glargine, detemir or degludec, compared to NPH insulin for T1D, assessing glycated hemoglobin (A1C) and hypoglycaemia. We restricted publication language to English, Spanish or Portuguese. Data sources included Medline, Cochrane Library, EMBASE and hand-searching. The methodological quality of included studies was independently assessed by two reviewers, using the Assessment of Multiple Systematic Reviews (AMSTAR) checklist for systematic reviews and Jadad scale for clinical trials. We conducted a funnel plot and Egger's test to assess the risk of bias across studies. Study Selection: We identified systematic reviews of randomized controlled trials with any publication date that evaluated the efficacy of long-acting insulin analogues glargine, detemir or degludec, compared to NPH insulin for T1D, assessing glycated hemoglobin (A1C) and hypoglycaemia. We found 11 eligible systematic reviews relevant to this overview 
that contained a total of 25 relevant clinical trials. Data Extraction: Two reviewers abstracted data and independently rated study quality.

Results: Compared to NPH insulin in A1C, the long-acting insulin analogue yielded a statistically but not clinically significant reduction of $0.17 \%\left(95 \% \mathrm{Cl}-0.23 ;-0.12 ; \mathrm{I}^{2}\right.$ $99.7 \%)$. For general and nocturnal hypoglycaemia, results suggested risk relative reduction of $5 \%$ and $34 \%$, respectively. Compared to NPH in severe hypoglycaemia, the long-acting insulin analogues did not have statistically significant results $(R R=$ $0.94 ; 95 \% \mathrm{Cl} 0.71 ; 1.24 ; \mathrm{I}^{2}$ 94.7\%).

Limitations: Although we had searched for insulin degludec, as it has more recently arrived on the market and there were no studies comparing it to $\mathrm{NPH}$, we only included the analogues glargine and detemir. We did not perform a new systematic review of RCTs.

Conclusions: This study is, from our knowledge, the first overview of systematic reviews assessing the efficacy of long-acting insulin analogues compared to NPH. This study design has allowed us to carry out the most comprehensive assessment of RCTs on this subject, filling a gap in diabetes research, since there are many overlapping systematic reviews with contradictory recommendations.

Keywords: diabetes mellitus, type 1; long-acting insulin analogue; systematic review; overview. 


\subsection{INTRODUCTION}

Intensive insulin therapy improves outcomes of patients with type 1 diabetes (T1D). These improvements include better glycemic control and a reduction in the risk of complications $(1,2,3)$, preventing or delaying the progression of chronic microvascular complications in approximately $50 \%$ of cases (1), which makes the treatment more effective. Although the importance of glycemic control has been known for approximately three decades (4), this control is still flawed in many countries. For example, glycemic control was unsatisfactory in $87 \%$ of Brazilian T1D patients (glycated hemoglobin, A1C > 7\%) in 2012 (5). This scenario has become a global concern since the number of people living with diabetes has almost quadrupled since 1980 to 422 million adults (6). It is estimated that T1D accounts for between 5 and $10 \%$ of all cases of diabetes (6), and the incidence rate increases by $3 \%$ a year (6).

The comparison between insulin analogues and human insulins has been investigated for decades, with many randomized controlled trials (RCTs) and systematic reviews giving mixed results $(7,8,9,10,11)$. This contradictory evidence has increased uncertainty on coverage decisions at health system level. For example, among the five countries with the highest number of people with T1D (China, India, the USA, Brazil and Russia), only the USA (12) and Russia (13) have clinical guidelines for T1D patients that include long-acting insulin analogues among the treatment options, under restricted indications.

To deal with the substantial increase in the number of overlapping systematic reviews, guidance on how to conduct overviews of systematic reviews has emerged since the mid-2000s $(14,15)$. The purpose of overviews is to summarize evidence, synthesizing results from multiple systematic reviews into a single, useful document $(15,16)$. Overviews identify high-quality, reliable systematic reviews and explore consistency of findings across reviews (15)Erro! Indicador não definido.. To the best of our knowledge, this is the first overview on the efficacy of long-acting insulin analogues compared to NPH for T1D. We sought to shed some light on this issue to support decision making from both clinical and public health perspectives.

In this context of doubt and uncertainty on the recommendations $(17,18)$ we aimed to conduct an overview of systematic reviews and also update existing 
reviews, aggregating clinical trials published to date and preparing a new metaanalysis to determine whether long-acting insulin analogues are effective and safe for T1D patients compared to NPH in reduction of hypoglycaemia and maintenance or improvement of glycemic control.

\subsection{METHODS}

\subsubsection{Design and Register}

We performed an overview of systematic reviews of RCTs (guided by the Cochrane Handbook (15)) on the efficacy of long-acting insulin analogues compared to NPH human insulin for T1D patients. We also updated systematic reviews included in this overview, by including RCTs published after publication of the systematic reviews. The protocol for this overview was registered in the International Prospective Register of Systematic Reviews (PROSPERO) under number CRD42016047137.

\subsubsection{Criteria for Considering Reviews for Inclusion}

We selected systematic reviews of RCTs that evaluated efficacy of long-acting insulin analogues compared to NPH human insulin for T1D patients. The inclusion criteria were: i) a direct or indirect comparison between long-acting insulin analogues and NPH; ii) T1D patients regardless age group; iii) results that included at least one of the primary outcomes related to efficacy (A1C, and general, severe and nocturnal hypoglycaemia).

In cases of eligible systematic reviews that included RCTs and other study designs, we included these reviews if it was possible to extract the RCTs results indenpendently. A similar procedure was applied for reviews that reported results for type 1 and type 2 diabetes. If several publications from the same author or group were identified, the publications were re-scanned to decide whether the reported reviews or trials were the same. In such cases, the most recent publication was selected unless the earlier one provided more information. Studies published as 
abstracts were included when sufficient information on methods and results was provided. We restricted our search to English, Spanish and Portuguese systematic reviews and studies in humans. There was no restriction on year of publication. We included both Cochrane and non-Cochrane reviews. We excluded studies that assessed pregnant patients, analyzed only rapid-acting insulin analogues as the intervention, or assessed outcomes other than A1C and hypoglycaemia.

To update the included systematic reviews, we performed a separate search for RCTs assessing long-acting insulin analogues as the intervention compared to $\mathrm{NPH}$ human insulin, and reporting outcomes as A1C (in terms of the difference between the end of study and baseline or the measures of the baseline and the end of study independently) and hypoglycaemia, considering the categories: general, severe and nocturnal (in terms of number of episodes or rate of episodes per persontime). Regarding the clinical trials located in the selected systematic reviews or in the complementary search, we considered only phase III RCTs, classified as Jadad $\geq 2$, which compared long-acting insulin analogues to $\mathrm{NPH}$, evaluating the outcomes of interest for inclusion in meta-analysis.

\subsubsection{Search Methods for Identification of Studies}

Potentially relevant systematic reviews were identified through a comprehensive and exhaustive search of electronic databases: the Cochrane Library, MEDLINE (via PubMed) and EMBASE. We conducted the first search in February 2015 and the last update in October 2016. We used a filter for systematic reviews and meta-analyses and for study language when this option was available at the database searched.

The search strategy was developed using MeSH terms for MEDLINE, EMTREE terms for Embase, and a combination of keywords for Cochrane Library. For example, the full electronic search strategy used at MEDLINE was: ("Diabetes Mellitus, Type 1" (Mesh) OR "Type 1 Diabetes Mellitus" (tiab) OR "IDDM" (tiab) OR "T1DM" (tiab)) AND (("long-acting insulin analogue " (tiab) OR "analogue long-acting insulin" (tiab) OR "analog\$ long-acting insulin\$" OR "long-acting analog\$ insulin" OR "basal insulin analogue" (tiab) OR "basal analog\$ insulin\$" OR " insulin\$ analog\$") 
OR ("glargine" (Supplementary Concept) OR "glargine" (tiab) OR "lantus" (tiab) OR "HOE 901" (tiab)) OR ("insulin detemir" (Supplementary Concept) OR "detemir" (tiab) OR "levemir" (tiab) OR "NN304" (tiab)) OR ("insulin degludec" (Supplementary Concept) OR "insulin degludec" (tiab) OR "degludec" (tiab) OR "tresiba" (tiab))) AND (Meta-Analysis(ptyp) OR systematic(sb)) AND (English(lang) OR Portuguese(lang) OR Spanish(lang)). This strategy was slightly adapted for use in EMBASE and Cochrane Library, as presented in Appendix A.

We also performed a separate search to check for RCTs published after the most recent systematic review included in our overview. We used the following strategy in MEDLINE (from 09/01/2013 to 29/10/2016): ("Diabetes Mellitus, Type 1" (MeSH) OR "Type 1 Diabetes Mellitus" (tiab) OR "IDDM" (tiab) OR "T1DM" (tiab)) AND (("long-acting insulin analogue " (tiab) OR "analogue long-acting insulin" (tiab) OR "analog\$ long-acting insulin\$" OR "long-acting analog\$ insulin" OR "basal insulin analogue" (tiab) OR "basal analog\$ insulin\$" OR " insulin\$ analog\$") OR ("glargine" (Supplementary Concept) OR "glargine" (tiab) OR "lantus" (tiab) OR "HOE 901" (tiab)) OR ("insulin detemir" (Supplementary Concept) OR "detemir" (tiab) OR "levemir" (tiab) OR "NN304" (tiab)) OR ("insulin degludec" (Supplementary Concept) OR "insulin degludec" (tiab) OR "degludec " (tiab) OR "tresiba"(tiab))) AND (English(lang) OR Portuguese(lang) OR Spanish(lang)) AND ((Randomized Controlled Trial(ptyp) OR Clinical Trial, Phase III(ptyp))).

The literature search was supplemented by a hand search for abstracts at specialized scientific journals on diabetes, conferences and meetings websites. We also search for unpublished studies at clinicaltrials.gov. In cases of incomplete data, authors were contacted to obtain additional information.

\subsubsection{Data Collection and Analysis}

Titles and abstracts were screened by two independent investigators (FOL and KRCA). Duplicates and those that did not meet the eligibility criteria were excluded. The remaining records were read in their entirety, and those suitable for the overview were selected. Disagreements were solved by consensus. 


\subsubsection{Data Extraction and Management}

Two researchers (FOL and KRCA) independently extracted data on to a standardized datasheet. In cases of disagreement, decisions were made by consensus. From systematic reviews, full reference, authors, year of publication, and included clinical trials were collected. For clinical trials found in the selected systematic reviews and the complementary search, we collected full reference, authors, year of publication, characteristics of participants, number of individuals in the study and in each comparison arm, description of interventions in each comparison group (including brand of insulin, frequency per day, period of day, associated bolus insulin), and information on the selected outcomes. For continuous variables $(A 1 C)$, we collected the mean difference (SMD) between the end of the study and the baseline and the standard deviation (SD) for all comparison groups. In case of missing data (i.e.SD), we tried to contact the authors, and in cases of no reply, we assumed $S D=0.05$. For dichotomous variables (general, severe and nocturnal hypoglycaemia), we used the number of episodes per person-week, which is calculated by dividing the total number of episodes in each group by the number of persons in each group adjusted by the time until a hypoglycaemia occurs. When studies reported only the rate of episodes per person-time (time other than a week), we disaggregated this rate to obtain the number of episodes. For cross-over trials, we considered the $\mathrm{A} 1 \mathrm{C}$ mean difference in the first period and the sum of hypoglycaemia episodes in both periods of analysis. For trials that analyzed two intervention groups (i.e.: the same drug but different frequency or time of injection), we considered the best $\mathrm{A} 1 \mathrm{C}$ results and summed the hypoglycaemia episodes of both groups. This was different from Rossetti and colleagues (19), who yielded the hypoglycaemia results as episodes per person-time, thus we considered the best results, as it was impossible to sum the rates.

In the case of two or more publications from the same study, we use the most complete in the analysis. In the case of trials reported in conference abstracts and published later, we refer to the full text. 


\subsubsection{Assessment of Methodological Quality of Included Reviews}

Quality of systematic reviews was assessed using the AMSTAR tool (20). Quality of the evidence for RCTs was assessed using Jadad modified scale (21). The original Jadad scale is formed by seven questions about the methodological quality of clinical trials. The modified Jadad scale has five questions, specifically: Was the study described as randomized? Was the method of randomization appropriate? Was the study described as double blind? Was the method of blinding appropriate? Was there a description of withdrawals and dropouts? Clinical trials with Jadad score less than 2 were excluded.

\subsubsection{Data Analysis}

A random effects meta-analysis was chosen a priori. For continuous data (A1C) we used the difference between the end of the study and the baseline and the SD for all comparison groups to calculate the mean difference as associate effect measure, and $95 \%$ confidence intervals by DerSimonian \& Laird method. For dichotomous data (general, severe and nocturnal hypoglycaemia) we calculated the relative risk as the effect measure. The measure for any type of hypoglycaemia considered in the analysis was number of episodes per person-week, so the relative risk should be interpreted as incidence density, likewise $95 \%$ confidence intervals by the Mantel-Haenszel method. For dichotomous outcomes in which studies reported 0 events in one treatment arm, we added 0.5 to the numerator and 1 to the denominator.

It is worth noting that for dichotomous outcomes the $\mathrm{N}$ in forest plots does not represent the number of individuals for each group in each study, but the number of person-week.

The chi-squared test was applied to measure heterogeneity between studies at the $p<0.10$ significance level. We adopted this $p$-value over the traditional $p<$ 0.05 to be more conservative as low power is attributed to the chi-squared test in meta-analyses when a small number of studies or studies of small sample size are 
considered (22). The magnitude of inconsistency was measured using I-squared $\left(\mathrm{I}^{2}\right)$ statistics. An $\mathrm{I}^{2}$ of $80 \%$ was considered high heterogeneity. For results above this threshold, we conducted sensitivity analyses to determine whether results of some subgroups separately affected the results. We performed subgroup analyses for (a) age group (adult and pediatric); (b) type of bolus insulin (i.e., regular human insulin, lispro, aspart or both); and (c) brand of long-acting insulin analogue assessed (i.e., glargine or detemir) (results not shown).

When heterogeneity could not be explained by subgroup analysis, we performed a meta-regression analysis, considering the variables: (a) age group; (b) type of bolus insulin; (c) brand of long-acting insulin analogues assessed; (d) Jadad score; and (e) frequency per day of insulin analogues; (f) if study design was crossover or not; (g) follow-up period; (h) definition of hypoglycaemia (just for general hypoglycaemia); and if study had provided standard deviation for A1C measures.

We assessed the potential for publication bias in meta-analyses using funnel plots and Egger's test $(23,24,25)$.

We used Stata version 11.0 for the statistical analysis.

\subsection{RESULTS}

\subsubsection{Description of Included Reviews}

Our search for systematic reviews yielded 284 references, of which 61 were duplicates. After removing duplicates and assessing titles and abstracts, 26 studies were identified for full-text reading. References excluded in this first phase were those outside the inclusion criteria. After the screening of full texts, 11 systematic reviews $(10,11,26,27,28,29,30,31,32,33,34)$ (three had been published twice $(35,36,37)$ ) met the overview inclusion criteria (Figure 2.1). Among the 11 included studies, we found seven original systematic reviews, four with meta-analysis $(28,30,31,32)$ and three without meta-analysis $(26,33,34)$, two indirect comparisons $(10,11)$ and two complete health technology assessment studies $(27,28)$. 
Characteristics of included and excluded studies from the eligibility phase are described in Appendix B and C, respectively.
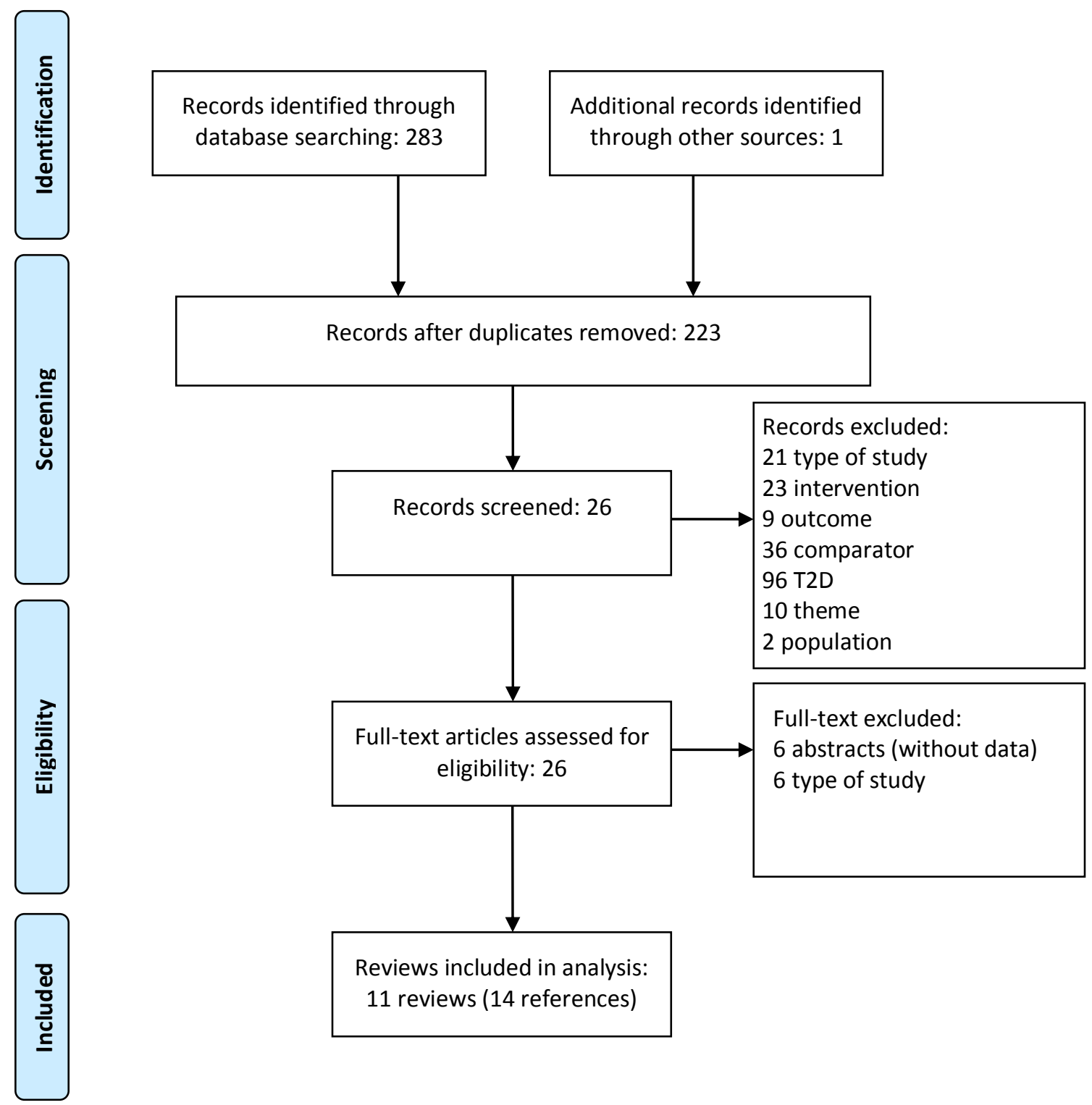

Figure 2.1 Flowchart of the study selection process for systematic reviews

Altogether the included systematic reviews yielded 62 references of RCTs. Among them, we included 25 in the analysis and excluded 37 that did not meet the pre-defined inclusion criteria or that did not measure selected outcomes appropriately. Characteristics of included and excluded trials are available in Appendix $D$ and $E$, respectively. The distribution of selected clinical trials among included in the systematic reviews is presented in Table 2.1. 
Table 2.1 - Distribution of considered clinical trials among included systematic reviews

\begin{tabular}{|c|c|c|c|c|c|c|c|c|c|c|c|}
\hline $\begin{array}{c}\text { Trials / Systematic } \\
\text { reviews }\end{array}$ & $\begin{array}{c}\text { Wang } \\
2003(26)\end{array}$ & $\begin{array}{l}\text { Warren } \\
2004(27)\end{array}$ & $\begin{array}{c}\text { Mullins } \\
2007(28)\end{array}$ & $\begin{array}{c}\text { Tran } \\
\text { 2007(29) }\end{array}$ & $\begin{array}{c}\text { Vardi } \\
2008(30)\end{array}$ & $\begin{array}{l}\text { Singh } \\
2009(31)\end{array}$ & $\begin{array}{l}\text { Sanches } \\
2011(11)\end{array}$ & $\begin{array}{c}\text { Szypowska } \\
2011(32)\end{array}$ & $\begin{array}{c}\text { Frier } \\
\text { 2013(33) }\end{array}$ & $\begin{array}{l}\text { Caires de } \\
\text { Souza } \\
2014(34)\end{array}$ & $\begin{array}{c}\text { Tricco } \\
\text { 2014(10) }\end{array}$ \\
\hline Raskin, 2000(38) & $\mathrm{x}$ & $\mathrm{x}$ & $\mathrm{x}$ & $\mathrm{x}$ & $\mathrm{x}$ & $\mathrm{x}$ & $\mathrm{x}$ & & & $\mathrm{x}$ & $\mathrm{x}$ \\
\hline Ratner, 2000(39) & $\mathrm{x}$ & $x$ & $x$ & $x$ & $x$ & $x$ & $x$ & & & & $x$ \\
\hline Hermansen 2001(40) & $x$ & & $x$ & $x$ & $x$ & & & & & & \\
\hline Schober, 2002(41) & $\mathrm{x}$ & & $\mathrm{x}$ & $\mathrm{x}$ & $\mathrm{x}$ & $\mathrm{x}$ & & & & $\mathrm{x}$ & \\
\hline Rossetti, 2003(42) & & & $\mathrm{x}$ & $\mathrm{x}$ & $\mathrm{x}$ & $\mathrm{x}$ & & & & & $\mathrm{x}$ \\
\hline Vague, 2003(43) & & & & $x$ & $x$ & $x$ & $x$ & $\mathrm{x}$ & $x$ & & $\mathrm{x}$ \\
\hline Murphy, 2003(44) & & & & & $x$ & $x$ & & & & & \\
\hline Porcellati, 2004(45) & & & & $x$ & $\mathrm{x}$ & $x$ & $\mathrm{x}$ & & & & $x$ \\
\hline Hermansen, 2004(46) & & & & & $\mathrm{x}$ & $\mathrm{x}$ & $\mathrm{x}$ & & $x$ & & \\
\hline Home, 2004(47) & & & & $\mathrm{x}$ & $\mathrm{x}$ & $\mathrm{x}$ & $x$ & $\mathrm{x}$ & $\mathrm{x}$ & & $\mathrm{x}$ \\
\hline $\begin{array}{l}\text { Russel-Jones, } \\
2004(48,49)\end{array}$ & & & & $x$ & $x$ & $x$ & $x$ & $x$ & $x$ & & $x$ \\
\hline Standl, 2004(50) & & & & $\mathrm{x}$ & & $x$ & & & $x$ & & $x$ \\
\hline Home, 2005(51) & & & & $\mathrm{x}$ & $\mathrm{x}$ & $\mathrm{x}$ & $\mathrm{x}$ & & & & \\
\hline Fulcher, 2005(52) & & & & $\mathrm{x}$ & $x$ & $x$ & $x$ & & & & $\mathrm{x}$ \\
\hline Pieber 2005(53) & & & & $\mathrm{x}$ & & $\mathrm{x}$ & $\mathrm{x}$ & $\mathrm{x}$ & $\mathrm{x}$ & & $\mathrm{x}$ \\
\hline NN 304-1476(54) & & & & & & & & $x$ & & & \\
\hline Ashwell, 2006(55) & & & & & $x$ & $x$ & & & & & $x$ \\
\hline Kolendorf, 2006(56) & & & & $x$ & $\mathrm{x}$ & $x$ & & $x$ & $x$ & & $\mathrm{x}$ \\
\hline Robertson, 2007(57) & & & & $x$ & $x$ & $x$ & & $x$ & & & \\
\hline Chatterjee, 2007(58) & & & & & $\mathrm{x}$ & $\mathrm{x}$ & & & & $x$ & $\mathrm{x}$ \\
\hline Mianovska, 2007(59) & & & & & & $x$ & & & & & \\
\hline Chase, 2008(60) & & & & & & $x$ & & & & $x$ & \\
\hline Bartley, 2008(61) & & & & & & & $x$ & $x$ & $x$ & & $x$ \\
\hline \multicolumn{12}{|l|}{ Hassan, 2008(62) } \\
\hline Bolli, 2009(63) & & & & & & $x$ & $x$ & & & & $x$ \\
\hline
\end{tabular}


In Table 2.1 we can observe that none of the included systematic reviews analyzed all the available clinical trials selected by this overview. Concerning completeness, the most complete included systematic review was Singh et al.(31), with 21 clinical trials. This does not mean that the reviews did not include more trials than analyzed here, but that some previously assessed trials were not included in this overview analysis, due to the inclusion criteria.

The complementary search for clinical trials yielded 49 references just from Medline (via Pubmed). After screening of titles, abstracts and full texts, we included three references $(64,65,66)$. Twenty-one references were excluded due to inappropriate comparison (to other comparator), 11 due to inappropriate interventions, four of each due to unsuitable outcome and study type, and two of each due to unsuitable population, diverse theme, and duplicates.

\subsubsection{Methodological Quality of Included Studies}

\subsubsection{Quality of Included Reviews}

Mean methodological quality of the 11 included systematic reviews was 7.28 (SD 3.03). Six of them presented methodological quality ranging from 8 to 11 points out of a maximum of 11 points on the AMSTAR score (Table 2.2). Almost all studies conducted a comprehensive literature search, evaluated scientific quality of the primary studies and used an appropriate method to combine the results. However, only three studies assessed the likelihood of publication bias $(10,30,31)$, and only four provided lists of both included and excluded studies $(27,28,29,30,32)$. No systematic review was excluded because of poor methodological quality. We considered that the main function of systematic reviews in this overview was to attend as a source for published clinical trials. 
Table 2.2 - The AMSTAR score of included systematic reviews

\begin{tabular}{|c|c|c|c|c|c|c|c|c|c|c|c|c|}
\hline \multirow[b]{2}{*}{ Systematic reviews } & \multicolumn{12}{|c|}{ AMSTAR item } \\
\hline & 1 & 2 & 3 & 4 & 5 & 6 & 7 & 8 & 9 & 10 & 11 & $\begin{array}{l}\text { \# of } \\
\text { YES }\end{array}$ \\
\hline Wang, 2003(26) & $\mathrm{N}$ & $\mathrm{N}$ & $\mathrm{Y}$ & $\bar{Y}$ & $\mathrm{~N}$ & $\bar{Y}$ & $\mathrm{~N}$ & $\mathrm{~N}$ & $\mathrm{~N}$ & $\mathrm{~N}$ & $\mathrm{~N}$ & 3 \\
\hline Warren, 2004(27) & $\mathrm{N}$ & $\mathrm{N}$ & $\mathrm{Y}$ & Y & Y & Y & Y & Y & Y & $\mathrm{N}$ & $\mathrm{Y}$ & 8 \\
\hline Mullins, 2007(28) & $\mathrm{N}$ & $\mathrm{N}$ & Y & $\mathrm{N}$ & $\mathrm{N}$ & Y & $\mathrm{N}$ & $\mathrm{N}$ & $\mathrm{N} / \mathrm{A}$ & $\mathrm{N}$ & $\mathrm{Y}$ & 3 \\
\hline Tran, 2007(29) & $\mathrm{Y}$ & $\mathrm{Y}$ & $\mathrm{Y}$ & Y & Y & Y & Y & Y & Y & $\mathrm{N}$ & $\mathrm{Y}$ & 10 \\
\hline Vardi, 2008(30) & $\mathrm{Y}$ & Y & Y & Y & Y & Y & Y & Y & Y & $\mathrm{Y}$ & $\mathrm{Y}$ & 11 \\
\hline Singh, 2009(31) & $\mathrm{Y}$ & $\mathrm{Y}$ & Y & Y & $\mathrm{N}$ & Y & Y & Y & Y & $\mathrm{Y}$ & $\mathrm{Y}$ & 10 \\
\hline Sanches, 2011(11) & $\mathrm{N}$ & $\mathrm{Y}$ & Y & Y & $\mathrm{N}$ & Y & Y & $\mathrm{N}$ & Y & $\mathrm{N}$ & $\mathrm{Y}$ & 7 \\
\hline Szypowska, 2011(32) & $\mathrm{N}$ & Y & Y & Y & $\mathrm{Y}$ & Y & Y & $\mathrm{N}$ & Y & $\mathrm{N}$ & $\mathrm{Y}$ & 8 \\
\hline Frier, 2013(33) & $\mathrm{N}$ & $\mathrm{N}$ & $\mathrm{N}$ & $\mathrm{N}$ & $\mathrm{N}$ & Y & Y & $\mathrm{N}$ & $N$ & $\mathrm{~N}$ & $\mathrm{Y}$ & 3 \\
\hline $\begin{array}{l}\text { Caires de Souza, } \\
2014(34)\end{array}$ & $\mathrm{Y}$ & $Y$ & $\mathrm{Y}$ & $\mathrm{N}$ & $\mathrm{N}$ & Y & Y & Y & NR & $\mathrm{N}$ & $\mathrm{Y}$ & 7 \\
\hline Tricco, 2014(10) & $Y$ & $Y$ & $Y$ & $Y$ & $\mathrm{~N}$ & Y & Y & Y & Y & $Y$ & $Y$ & 10 \\
\hline
\end{tabular}

Keys: N, no; NR, not reported; Y, yes (systematic review fulfilling the criteria); \# of Yes, number of yes; AMSTAR item: 1. Was an 'a priori' design provided? 2. Was there duplicate study selection and data extraction? 3. Was a comprehensive literature search performed? 4. Was the status of publication (i.e. grey literature) used as an inclusion criterion? 5. Was a list of studies (included and excluded) provided? 6. Were the characteristics of the included studies provided? 7. Was the scientific quality of the included studies assessed and documented? 8. Was the scientific quality of the included studies used appropriately in formulating conclusions? 9 . Were the methods used to combine the findings of studies appropriate? 10. Was the likelihood of publication bias assessed? 11. Was the conflict of interest included?

\subsubsection{Quality of Evidence in Included Reviews}

Combining the clinical trials located in the systematic reviews included in this overview and those found in the complementary search, 28 randomized clinical trials were analyzed. It is worth noting that the overview protocol has already indicated our decision to accept the fact that it was impossible to blind patients in these studies because the compared insulins have a different appearance; long-acting insulin analogues are transparent and NPH insulin is a suspension. Even if the authors had chosen individual pre-prepared doses, study subjects could trigger the injection mechanism (syringe or pen) and observe the color of the medication. In addition, a double-dummy strategy would not be recommended because it is considered unethical in this case. We therefore decided to include studies with Jadad $\geq 2$, since the lack of blindness necessarily takes $2 / 5$ points off the score. However, after analyzing the quality of all the studies, it was clear that evaluators' blindness was possible, and was successfully performed in three of the included studies. 
Concerning the methodological quality of evidence from these studies, they were all randomized and reported data for all individuals (per protocol, by intentionto-treat analysis, or both), justifying withdrawals and dropouts. Half the clinical trials presented appropriate randomization methods and just three had any level of blindness (Figure 2.2).

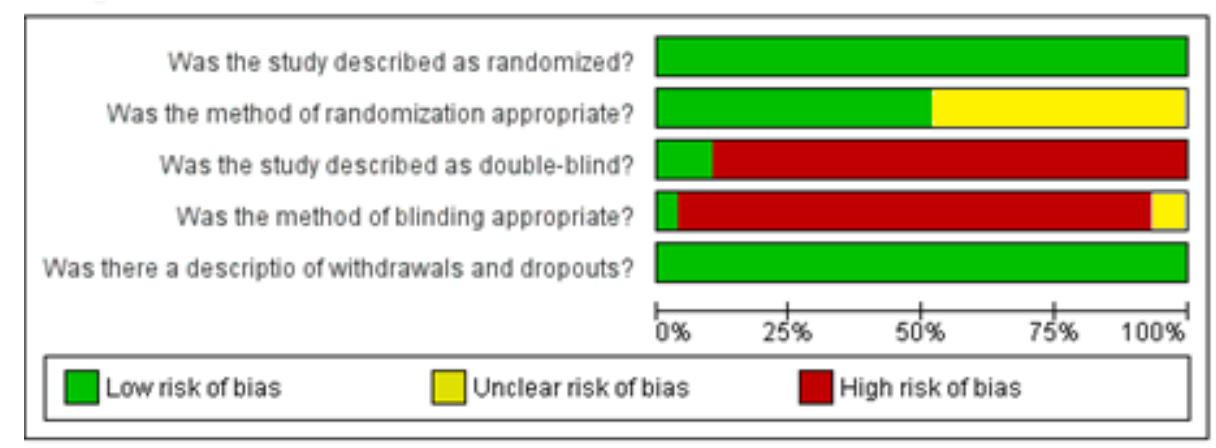

Figure 2.2 Risk of bias on included randomized clinical trials

\subsubsection{Quantitative Analysis}

\subsubsection{Meta-analysis}

Among all 28 included clinical trials, allocating 8158 individuals (cross-over studies counting twice), 4601 were randomized for insulin analogues and 3557 for $\mathrm{NPH}$ insulin. Seven references were cross-over studies $(40,44,55,56,58,59,66)$ and four were non-inferiority trials $(54,61,64,65)$. Concerning quantitative analysis, the outcomes that were most frequently analyzed were $\mathrm{A} 1 \mathrm{C}$ and general hypoglycaemia (25 trials).

In relation to $\mathrm{A} 1 \mathrm{C}$, the long-acting insulin analogue yielded a statistically significant reduction of $0,17 \%$ in $\mathrm{A} 1 \mathrm{C}$ mean difference, considering the difference between end of study and baseline $\left(95 \% \mathrm{Cl}-0.23 ;-0.12 ; \mathrm{I}^{2} 99.7 \%\right)$ compared to NPH insulin (Figure 2.3). This difference is clinically significant, as a difference in $\mathrm{A} 1 \mathrm{C}$ of $1.0 \%$ is already considered to be a minimal clinical threshold (67). 


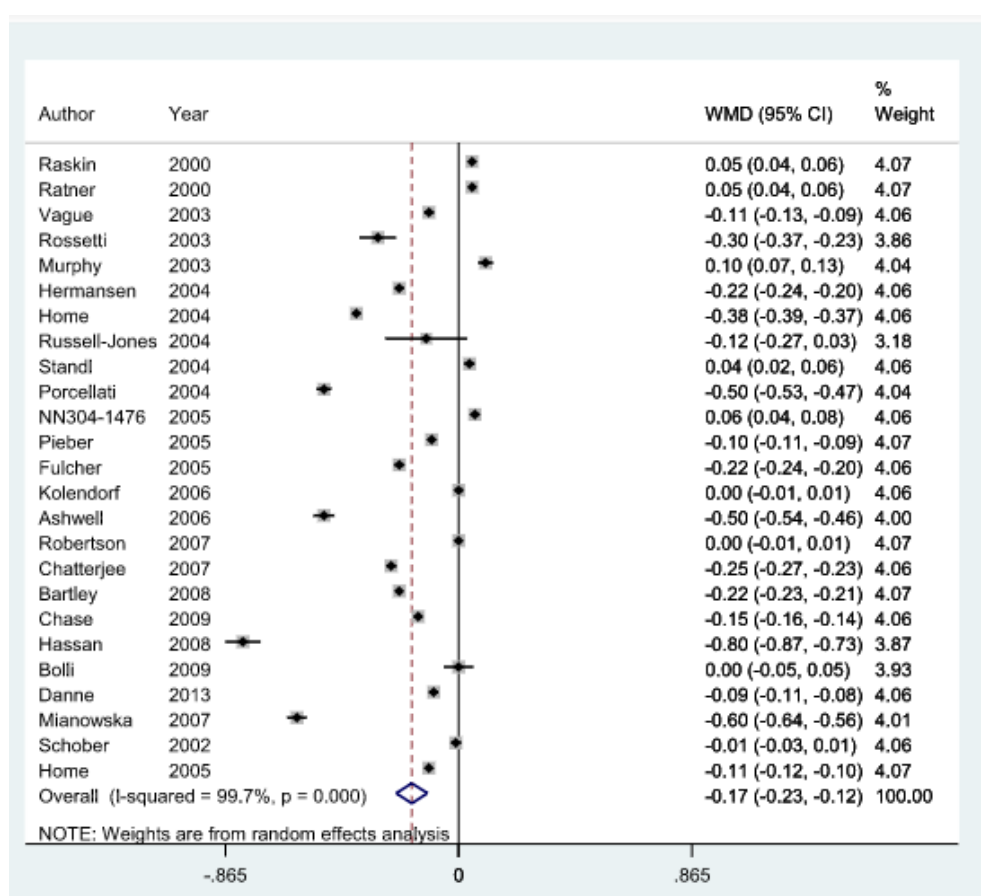

Figure 2.3 Meta-analysis of glycated hemoglobin - A1C

Regarding hypoglycaemia, its definition varied among the analyzed trials. Furthermore, authors have classified hypoglycaemia into many categories, such as general, overall, minor, severe, major, symptomatic, all day, day and nocturnal. We tried to group these categories into understandable classes; for instance, we included general, overall, minor and all day in the 'general' class, severe and major in the 'severe' class and maintained nocturnal as a separate class. The category "symptomatic" was assigned to the general or severe class, depending on the applied definition in the studies.

Considering general hypoglycaemia, the meta-analysis showed a statistically significant difference between the insulin analogue and $\mathrm{NPH}(\mathrm{RR}=0.95 ; 95 \% \mathrm{Cl}$ $0.91 ; 0.99 ; 1^{2} 97.5 \%$ ), favouring analogues with $5 \%$ less hypo (Figure 2.4 ). Although the effect was statistically significant, its magnitude and clinical significance were small. 


\begin{tabular}{|c|c|c|}
\hline $\begin{array}{l}\text { Study } \\
\text { ID }\end{array}$ & $\mathrm{RR}(95 \% \mathrm{Cl})$ & $\begin{array}{l}\% \\
\text { Weight }\end{array}$ \\
\hline raskin & $1.01(0.99,1.04)$ & 4.94 \\
\hline ratner & $0.60(0.51,0.70)$ & 2.88 \\
\hline hermansen & $0.84(0.76,0.92)$ & 4.00 \\
\hline vague & $0.86(0.84,0.88)$ & 4.95 \\
\hline rosseti & $0.69(0.46,1.02)$ & 0.90 \\
\hline murphy & $1.10(0.97,1.25)$ & 3.38 \\
\hline hermansen2 & $0.87(0.84,0.91)$ & 4.82 \\
\hline home & $1.25(1.18,1.33)$ & 4.55 \\
\hline russeljones & $0.98(0.95,1.00)$ & 4.95 \\
\hline standl & $0.80(0.78,0.83)$ & 4.89 \\
\hline porcellatti & $0.94(0.93,0.95)$ & 5.02 \\
\hline nn1476 & $1.03(1.01,1.06)$ & 4.94 \\
\hline pieber & $1.04(0.97,1.11)$ & 4.49 \\
\hline fulcher & $1.07(1.02,1.11)$ & 4.81 \\
\hline kolendorf & $0.91(0.87,0.96)$ & 4.69 \\
\hline ashwell & $0.99(0.94,1.03)$ & 4.73 \\
\hline robertson & $0.96(0.94,0.98)$ & 4.97 \\
\hline chatterjee & $0.98(0.86,1.12)$ & 3.41 \\
\hline bartley & $0.80(0.79,0.82)$ & 4.98 \\
\hline chase & $1.07(1.05,1.10)$ & 4.95 \\
\hline hassan & $0.13(0.02,1.06)$ & 0.04 \\
\hline bolli & $1.05(1.03,1.07)$ & 4.98 \\
\hline thalange & $0.89(0.88,0.91)$ & 4.99 \\
\hline danne & $1.15(0.79,1.67)$ & 0.99 \\
\hline pedersen & $0.81(0.63,1.04)$ & 1.77 \\
\hline Overall $(\mathrm{I}$-squared $=97.5 \%, \mathrm{p}=0.000)$ & $0.95(0.91,0.99)$ & 100.00 \\
\hline \multicolumn{3}{|l|}{ NOTE: Weights are from random effects analy \$is } \\
\hline .0163 & & \\
\hline
\end{tabular}

Figure 2.4 Meta-analysis of general hypoglycaemia

Data for severe hypoglycaemia were usefully available from 16 studies (Figure 2.5). Concerning this outcome, the pooled estimate of all trials using the random effects model showed long-acting insulin analogues did not have statistically significant results compared to $\mathrm{NPH}$, revealing a $\mathrm{RR}=0.94\left(95 \% \mathrm{Cl} 0.71 ; 1.24 ; \mathrm{I}^{2}\right.$ $94.7 \%)$.

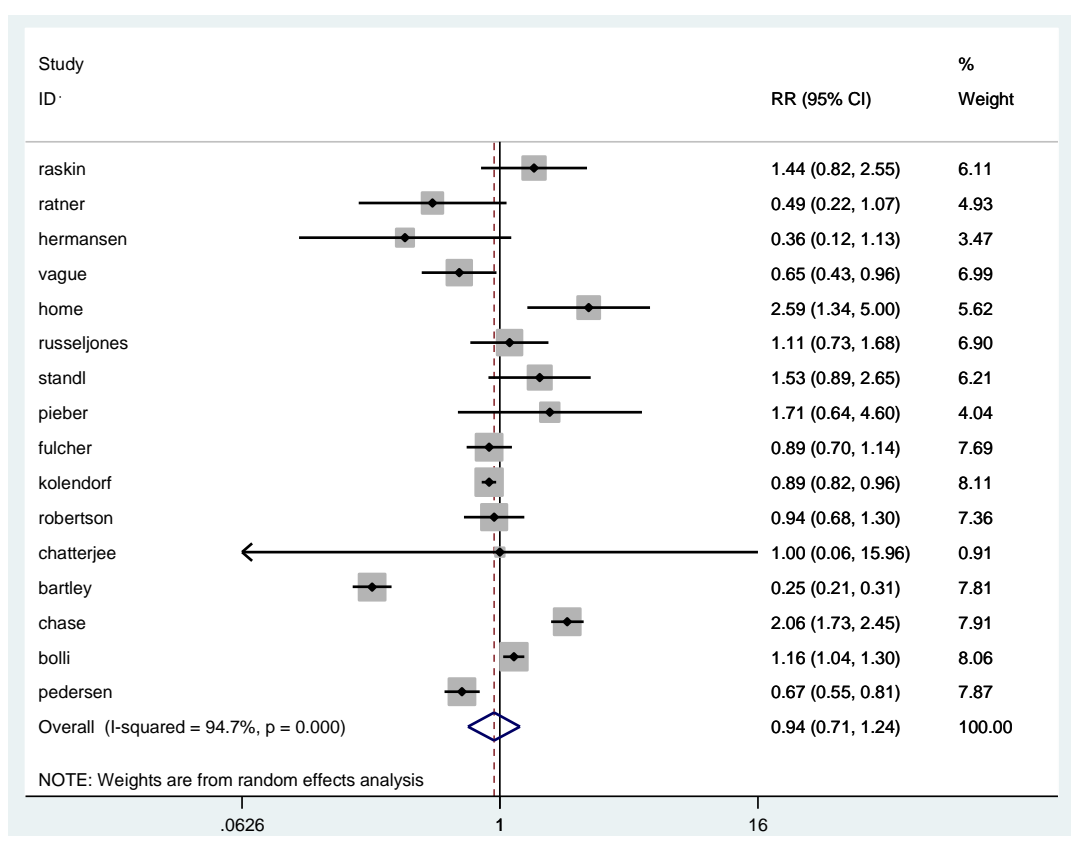

Figure 2.5 Meta-analysis of severe hypoglycaemia 
Concerning nocturnal hypoglycaemia, it was available from 20 clinical trials, and the meta-analysis results favor insulin analogues (RR $0.66 ; 95 \% \mathrm{Cl} 0.57 ; 0.76 ; \mathrm{I}^{2}$ $97.1 \%$ ), meaning that the risk of having a hypo episode was reduced by $34 \%$ on average (Figure 2.6).

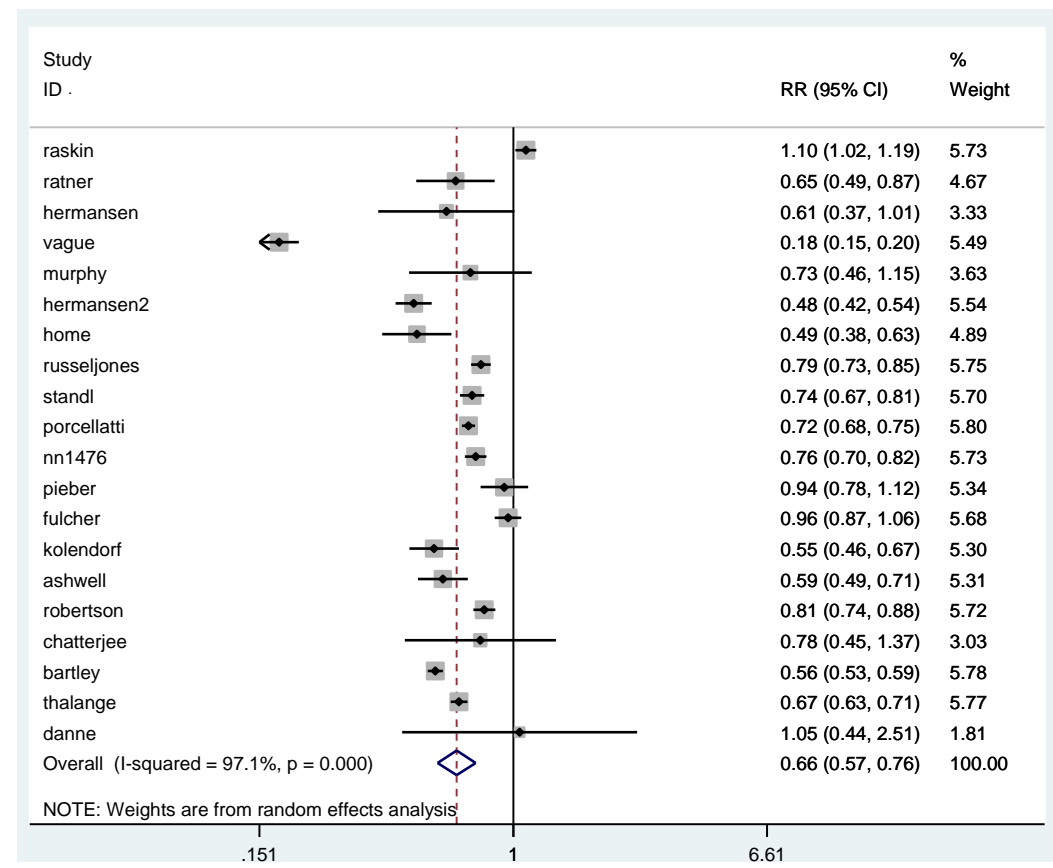

Figure 2.6 Meta-analysis of nocturnal hypoglycaemia

\subsubsection{Meta-regression}

Heterogeneity was impressive for all analyzed outcomes, being above $90 \%$. Concerning $\mathrm{A} 1 \mathrm{C}$, the high heterogeneity was partially explained in $15.96 \%$ by methodological quality $(p=0.07)$ and in $9.16 \%$ by duration of the study, but not statistically significant $(p=0.16)$. The heterogeneity in general hypoglycaemia was explained in $26.13 \%$ by bolus insulin ( $p=0.01$ ), in $13.96 \%$ by hypoglycaemia definition $(\mathrm{p}=0.10)$, and in $7.16 \%$ by duration of study $(\mathrm{p}=0.10)$. For nocturnal hypoglycaemia, it was explained in $23.71 \%$ by crossover design ( $p=0.08$ ) and in $13.55 \%$ by intervention brand $(p=0.08)$. For severe hypoglycaemia, heterogeneity was marginally explained by age in $3.84 \%(p=0.29)$. 


\subsubsection{Analysis of Publication Bias}

Visual inspection of Begg's funnel plots for hypoglycaemia endpoints (Figure 2.7 $A, B, C)$ showed a tendency of published trial results to have a small risk of publication bias and the Egger's test confirmed this direction for general $(p=0.75)$, severe $(p=0.68)$, and nocturnal hypoglycaemia $(p=0.74)$. However, A1C studies were very dispersed (Figure $2.7 \mathrm{D}$ ), suggesting that there is publication bias concerning this outcome, and this was confirmed by Egger's test $(p=0.05)$. 
38

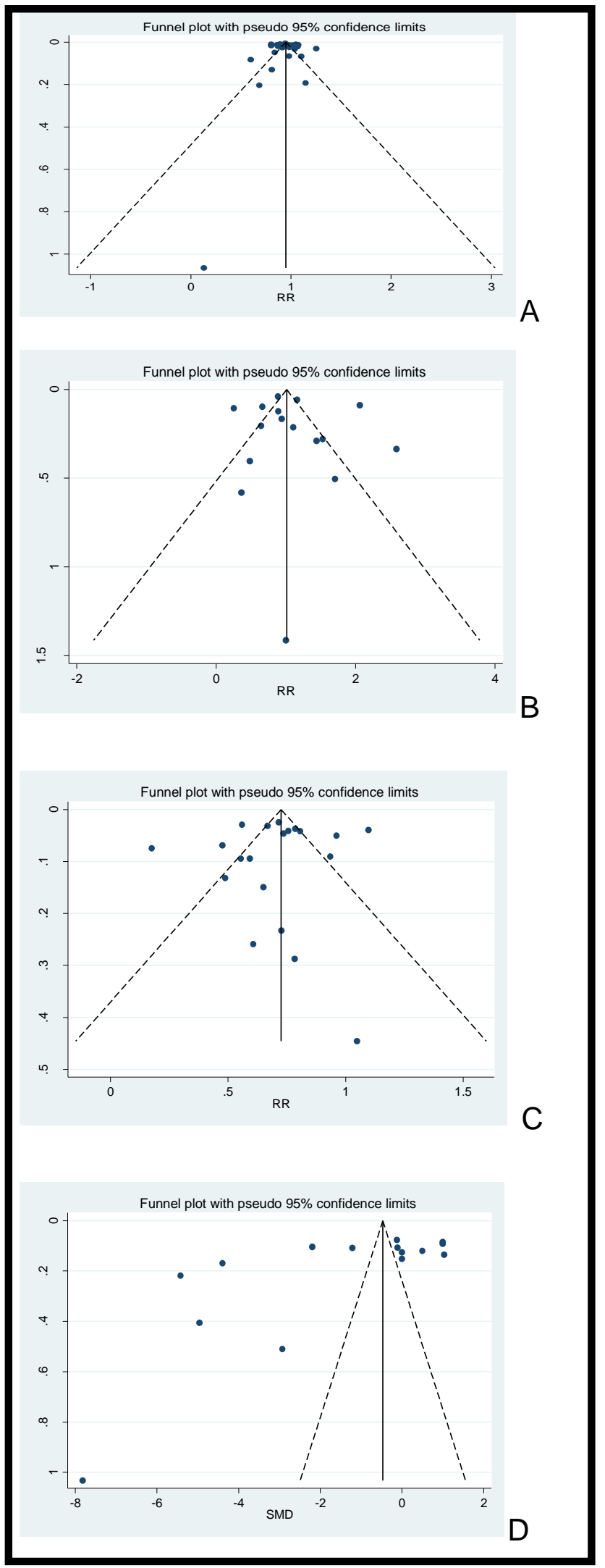

Figure 2.7 Publication bias analysis by Reg's funnel plots. A. General hypoglycaemia. B. Severe hypoglycaemia. C. Nocturnal hypoglycaemia. D A1C. 


\subsection{DISCUSSION}

To the best of our knowledge, this study is the first overview of systematic reviews to assess the efficacy of long-acting insulin compared to NPH. This study design has allowed us to carry out the most comprehensive assessment of RCTs on this subject, filling a gap in diabetes research, since there are many overlapping systematic reviews with contradictory recommendations. We found evidence that long-acting insulin analogues are efficacious compared to $\mathrm{NPH}$, with estimates showing a reduction in nocturnal hypoglycaemia episodes by 34\% (RR 0.66) and general hypoglycaemia episodes by $5 \%(\mathrm{RR}=0.95)$. Further results showed a nonclinically significance reduction in $\mathrm{A} 1 \mathrm{C}$ of $0.17 \%$.

Our study used appropriate outcome measures for the outcomes included in the analysis, similar to other previously published systematic reviews $(28,30)$. Of the 11 reviews included in this overview, only three $(28,30,31)$ reported the measure of hypoglycaemia as episodes per person-time, as recommended by methodological guidelines (15,68). The other reviews $(10,11,26,29,32,33,34)$ reported hypoglycaemia as the risk of having at least one event during the study (number of people who had hypoglycaemia/ number of people in the study group). This is a misconception, given that each person could experience more than one event during the whole study follow-up. Regarding the A1C measure, three reviews $(31,33,34)$ reported only the comparison of the final $\mathrm{A} 1 \mathrm{C}$ between groups. Using such a measure is not appropriate, since the measure of interest should be how much the interventions have decreased $\mathrm{A} 1 \mathrm{C}$, it being more appropriate to measure $\mathrm{A} 1 \mathrm{C}$ difference between the end of the study and baseline (69), as we reported.

Among the systematic reviews that assessed outcomes similar way to this overview, Vardi and collaborators (30), in a Cochrane review, yielded comparable results to our overview concerning hypoglycaemia. Results showed the reduction was not statistically significant in general hypoglycaemia (OR $0.93 ; 95 \% \mathrm{Cl} 0.8 ; 1.08$ ) (30). For severe hypoglycaemia, for which overview results were not statistically significant, Vardi and colleagues showed a reduction of $27 \%$ (OR $0.73 ; 95 \% \mathrm{Cl} 0.61$; 0.87 ) and for nocturnal hypoglycaemia, the results were in the same direction, with a significant reduction favouring insulin analogue (OR $0.70 ; 95 \% \mathrm{Cl} 0.63 ; 0.79)$ (30). The results of Singh and colleagues' review (31) are very similar to ours. Nocturnal 
hypoglycaemia was reduced in insulin analogues in 35\% (OR 0.65; 95\% Cl 0.55;0.77) (31).

Regarding clinical trials, it is worth noting that first pilot studies are usually misunderstood. Considering dose titration phases, the proportion of patients experiencing hypoglycaemia episodes during the titration period was higher for insulin analogues than for NPH in the first trials $(26,38,39,70,71)$. Titration could bring several biases to the interpretation of the results, considering the use of equal doses for NPH and analogues. Thus, a substantial number of hypos in the analogues group was noted. In conclusion, neither hypoglycaemia episodes nor A1C in the titration period should be included in the results, according to Food and Drug Administration recommendations: "The primary efficacy parameter should be assessed substantially after the end of the titration period (e.g., 3 months) to better reflect the steady-state effect of the dose regimens studied" (69).

Two other major challenges when analyzing RCTs in T1D are the different ways of measuring hypoglycaemia and the short follow-up of studies. Regarding the definition of hypoglycaemia, this varies across the studies $(<2.0 \mathrm{mmol} / \mathrm{L},<2.8 \mathrm{mmol}$ / L, $<3.1 \mathrm{mmol} / \mathrm{L},<4.0 \mathrm{mmol} / \mathrm{L}$ ), contributing $14 \%$ to the heterogeneity of general hypoglycaemia in our analysis. Recommendations from the American Diabetes Association Workgroup on Hypoglycaemia (72) and the International Society for Pediatric and Adolescent Diabetes (73), which stratify and define hypoglycaemia appropriately, have been published. However, many of the studies, published later than these recommendations, do not use them.

Regarding the duration of the studies, it is important to criticize studies with less than 12 weeks of follow-up. This is insufficient time to capture changes in a chronic disease, mainly related to $\mathrm{A} 1 \mathrm{C}$, which is known to take three months (or 12 weeks) to present changes caused by interventions or treatments $(69,73)$.

Some authors and regulatory agencies around the world point to the lack of efficacy of insulin analogues for three reasons: presentation of results based on a surrogate endpoint; absence or small magnitude of difference in $\mathrm{A} 1 \mathrm{C}$; and high heterogeneity in meta-analytical analysis. These points are controversial, as we highlight in the following paragraphs.

Regarding account $\mathrm{A} 1 \mathrm{C}$ as a surrogate outcome, researchers in evidencebased medicine, among them the creators of the GRADE instrument, have proposed quality criteria to evaluate studies with surrogate outcomes. These authors (75) have 
stated that surrogate outcomes should be considered relevant if they can establish a direct relationship between the surrogate outcome and the clinical outcome it is intended to replace. The evidence of significance for A1C occurs through the largest clinical trial in T1D and its extension, DCCT (1) and EDIC (76). The results of these studies established the relationship between a $1 \%$ decrease in $\mathrm{A} 1 \mathrm{C}$ and at least a $43 \%$ decrease in microvascular complications. Such reduction of $1 \%$ is internationally accepted as clinically significant (69).

Regarding the small magnitude of the effect of long-acting insulin analogues in A1C, it is important to remember that its primary role in the algorithm for treating T1D is to improve glucose control and decrease the risk of hypoglycaemia. Therefore, since $\mathrm{A} 1 \mathrm{C}$ is an average of the glycaemia of the last three months, we can see the fact that these insulins decrease the occurrence of hypoglycaemia (lower limit of the mean) as positive, providing maintenance or even little improvement of A1C (74), as occurs in this overview.

Heterogeneity was high and significant, being greater than $90 \%$ in all outcomes considered in our overview. The variables that most explained the heterogeneity were bolus insulin (26\%) and definition of hypo (14\%) for general hypoglycaemia, cross-over design (23\%) and intervention brand (13\%) for nocturnal hypoglycaemia, and Jadad score (16\%) for A1C. Two other factors have influenced the inconsistency of the results, but their impact was not clear: i) the fact that the rate of episodes per person-time was calculated for most of the studies, and the absence of standard deviation estimates for A1C in some meta-analysis. High heterogeneity was common among the systematic reviews analyzed in this overview $(10,30,31)$. It is worth noting that a portion of the heterogeneity could not be explained by the variables studied in this overview.

Some limitations of our study should be acknowledged. First, we did not include insulin degludec in our overview. Although it is one the most recent longacting insulins on the market, we did not identify any study comparing it to NPH. Second, we excluded some conference abstracts due to the low methodological quality of the reports, often with insufficient data for analysis. Third, when we searched for new RCTs published after the last systematic review included in our overview, we only searched Medline, i.e. we did not carry out a full systematic review of RCTs. 
To date, some indirect comparison analyses have been performed $(10,11,77)$, but none of them included all the therapeutic options available in terms of basal insulins. Thus, as a recommendation for future research, we suggest performing indirect comparison analysis or network meta-analysis including all basal profile insulins, such as NPH, glargine, detemir, degludec (78), lispro protamine suspension (79), peglispro (80), glargine $300 \mathrm{U} / \mathrm{ml}$ (81), pre-mixed (82), and biosimilars insulins (83). This latter may represent hope for population access to better insulins at an affordable cost for public health systems in developing countries $(84,85,86,87)$. 


\section{REFERENCES}

1. Diabetes Control and Complications Trial Research Group. The effect of intensive treatment of diabetes on the development and progression of long-term complications in insulin-dependent diabetes mellitus. N Engl J Med. 1993 Sep 30;1993(329):977-86.

2. White $\mathrm{NH}$, et al. Beneficial effects of intensive therapy of diabetes during adolescence: outcomes after the conclusion of the Diabetes Control and Complications Trial (DCCT). J Pediatr. 2001;139(6):804-12.

3. National Institute for Clinical Excellence. Type 1 diabetes: the diagnosis and management of type 1 diabetes in adults. Clinical Guideline \#15, 2004. Update In progress. Available: www.nice.org.uk/CG015NICEguideline.

4. Nathan DM, DCCT/Edic Research Group. The diabetes control and complications trial/epidemiology of diabetes interventions and complications study at 30 years: overview. Diabetes care. 2014 Jan 1;37(1):9-16.

5. Gomes MB, Coral M, Cobas RA, Dib SA, Canani LH, Nery M, et al. Prevalence of adults with type 1 diabetes who meet the goals of care in daily clinical practice: a nationwide multicenter study in Brazil. Diabetes Res Clin Pract. 2012;97:63-70.

6. International Diabetes Federation. IDF Diabetes Atlas. 2015. ISBN: 2-930229-853. Available: http:// www.idf.org/diabetesatlas.

7. Russell-Jones D, Simpson R, Hylleberg B, et al. Effects of QD insulin detemir or neutral protamine Hagedorn on blood glucose control in patients with type I diabetes mellitus using a basal-bolus regimen. Clin Ther. 2004;26:724-736.

8. Home P, Bartley P, Russell-Jones D, et al.; Study to Evaluate the Administration of Detemir Insulin Efficacy, Safety and Suitability (STEADINESS) Study Group. Insulin detemir offers improved glycemic control compared with NPH insulin in people with type 1 diabetes: a randomized clinical trial. Diabetes Care. 2004;27:1081-1087. 9. Bartley PC, Bogoev M, Larsen J, Philotheou A. Long-term efficacy and safety of insulin detemir compared to Neutral Protamine Hagedorn insulin in patients with Type 1 diabetes using a treat-to-target basal-bolus regimen with insulin aspart at meals: a 2-year, randomized, controlled trial. Diabet Med. 2008;25:442-449. 
10. Tricco A.C. Ashoor H.M. Antony J. Beyene J. Veroniki A.A. Isaranuwatchai W. Harrington A. Wilson C. Tsouros S. Soobiah C. Yu C.H. Hutton B. Hoch J.S. Hemmelgarn B.R. Moher D. Majumdar S.R. Straus S.E. Safety, effectiveness, and cost effectiveness of long acting versus intermediate acting insulin for patients with type 1 diabetes: Systematic review and network meta-analysis. BMJ (Online) 2014 Oct 1; 349:g5459.

11. Sanches AC, Correr CJ, Venson R, Pontarolo R. Revisiting the efficacy of longacting insulin analogues on adults with type 1 diabetes using mixed-treatment comparisons. Diabetes Res Clin Pract. 2011.

12. American Diabetes Association. American Diabetes Association standards of medical care in diabetes 2016. Diabetes Care January 2016; 39(supp 1). Available in:

http://care.diabetesjournals.org/content/suppl/2015/12/21/39.Supplement_1.DC2/201 6-Standards-of-Care.pdf.

13. Doničová V, Brož J, Sorin I. Health Care Provision for People with Diabetes and Postgraduate Training of Diabetes Specialists in Eastern European Countries. Journal of Diabetes Science and Technology 2011 Sep, 5(5):1124-1136.

14. Pollock M, Fernandes RM, Becker LA, Featherstone R, Hartling L. What guidance is available for researchers conducting overviews of reviews of healthcare interventions? A scoping review and qualitative metasummary. Pollock et al. Systematic Reviews 2016;5:190 DOI 10.1186/s13643-016-0367-5.

15. Becker LA, Oxman AD. Chapter 22: Overviews of reviews. In: Higgins JPT, Green S (editors), Cochrane Handbook for Systematic Reviews of Interventions Version 5.1.0 (updated March 2011). The Cochrane Collaboration, 2011. Available from www.cochrane-handbook.org.

16. Cheung A, Weir M, Mayhew A, Kozloff N, Brown K, Grimshaw J. Overview of systematic reviews of the effectiveness of reminders in improving healthcare professional behavior. Systematic reviews. 2012 Aug 16;1(1):1.

17. Holden SE, Currie CJ. Do the benefits of analog insulins justify their costs? Diabetes Manage. 2012;2(3):173-175.

18. Grunberger G. Insulin Analogs: Are They Worth It? Yes! Diabetes Care 2014;37:1767-1770.

19. Rossetti P, Pampanelli S, Fanelli C, Porcellati F, Costa E, Torlone E, et al. Intensive replacement of basal insulin in patients with type 1 diabetes given rapid- 
acting insulin analog at mealtime: a 3-month comparison between administration of $\mathrm{NPH}$ insulin four times daily and glargine insulin at dinner or bedtime. Diabetes Care 2003;26:1490-6.

20. Shea BJ, Grimshaw JM, Wells GA, Boers M, Andersson N, Hamel C, Porter AC, Tugwell P, Moher D, Bouter LM. Development of AMSTAR: a measurement tool to assess the methodological quality of systematic reviews. BMC medical research methodology. 2007 Feb 15;7(1):1.

21. Jadad AR, Moore RA, Carroll D, et al. Assessing the quality of reports of randomized clinical trials: is blinding necessary? Control Clin Trials. 1996;17:1-12. 22. Higgins JP, Thompson SG, Deeks JJ, Altman DG. Measuring inconsistency in meta-analyses. BMJ. 2003; 327(7414):557-60.

23. Sterne JAC, Kirkwood BR. Essential Medical Statistics. 2Ed. ed2003.

24. Egger M, Davey Smith G, Schneider M, Minder C. Bias in meta-analysis detected by a simple, graphical test. BMJ. 1997;315(7109):629-34.

25. Sterne JA, Sutton AJ, loannidis JP, Terrin N, Jones DR, Lau J, et al. Recommendations for examining and interpreting funnel plot asymmetry in metaanalyses of randomised controlled trials. BMJ. 2011;343:d4002.

26. Wang F, Carabino JM, Vergara CM. Insulin glargine: a systematic review of a long-acting insulin analogue. Clin Ther. 2003 Jun;25(6):1541-77.

27. Warren E. Weatherley-Jones E. Chilcott J. Beverley C. Systematic review and economic evaluation of a long-acting insulin analogue, insulin glargine. Health Technology Assessment 2004 8(45):iii-41.

28. Mullins P. Sharplin P. Yki-Jarvinen H. Riddle M.C. Haring H.-U. Negative Binomial Meta-Regression Analysis of Combined Glycosylated Hemoglobin and Hypoglycemia Outcomes Across Eleven Phase III and IV Studies of Insulin Glargine Compared with Neutral Protamine Hagedorn Insulin in Type 1 and Type 2 Diabetes Mellitus. Clinical Therapeutics 2007;29(8):1607-1619.

29. Tran K, Banerjee S, Li H, Cimon K, Daneman D, Simpson SH, Campbell K. Longacting insulin analogues for diabetes mellitus: meta-analysis of clinical outcomes and assessment of cost-effectiveness (Technology Report number 92). Ottawa: Canadian Agency for Drugs and Technologies in Health; 2007.

30. Vardi M. Jacobson E. Nini A. Bitterman H. Intermediate acting versus long acting insulin for type 1 diabetes mellitus. Cochrane Database of Systematic Reviews (2008):3. Article Number: CD006297. 
31. Singh S.R. Ahmad F. Lal A. Yu C. Bai Z. Bpharm H.B. Efficacy and safety of insulin analogues for the management of diabetes mellitus: A meta-analysis. CMAJ 2009;180(4): 385-397.

32. Szypowska A, Golicki D, Groele L, Pańkowska E. Long-acting insulin analogue detemir compared with NPH insulin in type 1 diabetes: a systematic review and metaanalysis. Pol Arch Med Wewn. 2011 Jul-Aug;121(7-8):237-46.

33. Frier BM, Russell-Jones D, Heise T. A comparison of insulin detemir and neutral protamine Hagedorn (isophane) insulin in the treatment of diabetes: a systematic review. Diabetes Obes Metab. 2013 Nov;15(11):978-86.

34. Caires de Souza AL, de Assis Acurcio F, Guerra Júnior AA, Rezende Macedo do Nascimento RC, Godman B, Diniz LM. Insulin glargine in a Brazilian state: should the government disinvest? An assessment based on a systematic review. Appl Health Econ Health Policy. 2014 Feb;12(1):19-32.

35. Szypowska A, Golicki D, Groele L, Pańkowska. Better metabolic control, less hypoglycaemia and less weight gain with insulin detemir versus NPH insulin in intensive insulin therapy for patients with type 1 diabetes. A meta-analysis.

Diabetologia 2009;52(S1):S387.

36. Sanches ACC, Correr CJ, Venson R, Gonçalves PR, Garcia MM, Piantavini MS, Pontarolo R. Insulin analogues Versus Human Insulin in Type 1 diabetes: Direct and indirect meta-analyses of efficacy and safety. Brazilian Journal of Pharmaceutical Sciences 2013;49(3):501-509.

37. Godman B, De Souza A, Acurcio F, Guerra JrA. Insulin glargine in a Brazilian state: An assessment of drug utilization, effectiveness and value to provide future direction. Basic and Clinical Pharmacology and Toxicology 2014;115(SUPPL 1):72. 38. Raskin P, Klaff L, Bergenstal R, Halle JP, Donley D, Mecca T. A 16-week comparison of the novel insulin analog insulin glargine (HOE 901) and NPH human insulin used with insulin lispro in patients with type 1 diabetes. Diabetes Care 2000;23:1666-71.

39. Ratner RE, Hirsch IB, Neifing JL, Garg SK, Mecca TE, Wilson CA. Less hypoglycemia with insulin glargine in intensive insulin therapy for type 1 diabetes. Diabetes Care 2000;23:639-43.

40. Hermansen K, Madsbad S, Perrild H, Kristensen A, Axelsen M. Comparison of the soluble basal insulin analog insulin detemir with NPH insulin: a randomized open 
crossover trial in type 1 diabetic subjects on basal- bolus therapy. Diabetes Care $2001 ; 24(2): 296-301$.

41. Schober E, Schoenle E, Van Dyk J, et al.; the Pediatric Study Group on Insulin Glargine. Comparative trial between insulin glargine and NPH insulin in children and adolescents with type 1 diabetes mellitus. J Pediatr Endocrinol Metab 2002;15:36976.

42. Rossetti P, Pampanelli S, Fanelli C, Porcellati F, Costa E, Torlone E, et al. Intensive replacement of basal insulin in patients with type 1 diabetes given rapidacting insulin analog at mealtime: a 3-month comparison between administration of $\mathrm{NPH}$ insulin four times daily and glargine insulin at dinner or bedtime. Diabetes Care 2003;26:1490-6.

43. Vague P, Selam JL, Skeie S, De Leeuw I, Elte JW, Haahr H, et al. Insulin detemir is associated with more predictable glycemic control and reduced risk of hypoglycemia than NPH insulin in patients with type 1 diabetes on a basal-bolus regimen with premeal insulin aspart. Diabetes Care 2003;26:590-6.

44. Murphy NP, Keane SM, Ong KK, Ford-Adams M, Edge JA, Acerini CL, Dunger DB: Randomized cross-over trial of insulin glargine plus lispro or NPH insulin plus regular human insulin in adolescents with type 1 diabetes on intensive insulin regimens. Diabetes Care 2003;26:799-804.

45. Porcellati F, Rossetti P, Pampanelli S, Fanelli CG, Torlone E, Scionti L, et al. Better long-term glycaemic control with the basal insulin glargine as compared with $\mathrm{NPH}$ in patients with type 1 diabetes mellitus given meal-time lispro insulin. Diabet Med 2004;21:1213-20.

46. Hermansen K, Fontaine P, Kukolja KK, Peterkova V, Leth G, Gall MA. Insulin analogues (insulin detemir and insulin aspart) versus traditional human insulins (NPH insulin and regular human insulin) in basal-bolus therapy for patients with type 1 diabetes. Diabetologia 2004;47:622-629.

47. Home P, Bartley P, Russell-Jones D, et al.; Study to Evaluate the Administration of Detemir Insulin Efficacy, Safety and Suitability (STEADINESS) Study Group. Insulin detemir offers improved glycemic control compared with NPH insulin in people with type 1 diabetes: a randomized clinical trial. Diabetes Care. 2004;27:1081-1087. 48. Home P, Bartley P, Landin-Olsson M, Russell-Jones D, Hylleberg B, Draeger E. Insulin detemir offers improved glycemic control, less weight gain, and flexible timing of administration compared to NPH insulin. Diabetes 2003;52(Suppl.1):A122. 
49. Russell-Jones D, Simpson R, Hylleberg B, et al. Effects of QD insulin detemir or neutral protamine Hagedorn on blood glucose control in patients with type I diabetes mellitus using a basal-bolus regimen. Clin Ther. 2004;26:724-736.

50. Standl E, Lang H, Roberts A. The 12-month efficacy and safety of insulin detemir and NPH insulin in basal bolus therapy for the treatment of type 1 diabetes. Diabetes Technol Ther 2004;6:579-588.

51. Home PD, Rosskamp R, Forjanic-Klapproth J, Dressler A; European Insulin Glargine Study Group. A randomized multicentre trial of insulin glargine compared with NPH insulin in people with type 1 diabetes. Diabetes Metab Res Rev. 2005 NovDec;21(6):545-53.

52. Fulcher GR, Gilbert RE, Yue DK: Glargine is superior to neutral protamine Hagedorn for improving glycated haemoglobin and fasting blood glucose levels during intensive insulin therapy. Intern Med J 2005;35:536-542.

53. Pieber TR, Draeger E, Kristensen A, Grill V. Comparison of three multiple injection regimens for type 1 diabetes: morning plus dinner or bedtime administration of insulin detemir vs. morning plus bedtime NPH insulin. Diabet Med. 2005;22:850857.

54. Trial NN304-1476. Integrated Clinical Trial Report. http://novonordisktrials.com/website/pdf/registry/bin_20 070 524-020 347-264.pdf

55. Ashwell SG, Amiel SA, Bilous RW, Dashora U, Heller SR, Hepburn DA, Shutler SD, Stephens JW, Home PD: Improved glycaemic control with insulin glargine plus insulin lispro: a multicentre, randomized, cross-over trial in people with Type 1 diabetes. Diabet Med 2006;23:285-292.

56. Kølendorf K, Ross GP. Pavlic-Renar et al. Insulin detemir lowers the risk of hypoglycaemia and provides more consistent plasma glucose levels compared with NPH insulin in type 1 diabetes. Diabet Med 2006;23:729-735.

57. Robertson KJ, Schoenle E, Gucev Z, et al. Insulin detemir compared with NPH insulin in children and adolescents with type 1 diabetes. Diabet Med. 2007; 24: 2734.

58. Chatterjee S, Jarvis-Kay J, Rengarajan T, Lawrence IG, McNally PG, Davies MJ: Glargine versus NPH insulin: efficacy in comparison with insulin aspart in a basal bolus regimen in type 1 diabetes-the glargine and aspart study (GLASS) a randomised cross-over study. Diabetes Res Clin Pract 2007;77:215-222. 
59. Mianowska B, Szadkowska A, Czerniawska E, Pietrzak I, Bodalski J. Insulin glargine improves fasting blood glucose levels in prepubertal children with unsatisfactorily controlled type 1 diabetes. Pediatr Endocrinol Diabetes Metab 2007;13:189-193.

60. Chase HP, Arslanian S, White NH, Tamborlane WV. Insulin glargine versus intermediate-acting insulin as the basal component of multiple daily injection regimens for adolescents with type 1 Diabetes Mellitus. J Pediatr. 2008;153:547-553. 61. Bartley PC, Bogoev M, Larsen J, Philotheou A. Long-term efficacy and safety of insulin detemir compared to Neutral Protamine Hagedorn insulin in patients with Type 1 diabetes using a treat-to-target basal-bolus regimen with insulin aspart at meals: a 2-year, randomized, controlled trial. Diabet Med. 2008;25:442-449.

62. Hassan K, Rodriguez LM, Johnson SE, Tadlock S, Heptulla RA: A randomized, controlled trial comparing twice-a-day insulin glargine mixed with rapid-acting insulin analogs versus standard neutral protamine Hagedorn (NPH) therapy in newly diagnosed type 1 diabetes. Pediatrics 2008;121:e466-e472.

63. Bolli GB, Songini M, Trovati M, Del Prato S, Ghirlanda G, Cordera R, Trevisan R, Riccardi G, Noacco C. Lower fasting blood glucose, glucose variability and nocturnal hypoglycaemia with glargine vs NPH basal insulin in subjects with Type 1 diabetes. Nutrition, Metabolism \& Cardiovascular Diseases. 2009;19:571-579.

64. Danne T, Philotheou A, Goldman D, Guo X, Ping L, Cali A, Johnston P. A randomized trial comparing the rate of hypoglycemia--assessed using continuous glucose monitoring--in 125 preschool children with type 1 diabetes treated with insulin glargine or NPHinsulin (the PRESCHOOL study). Pediatr Diabetes. 2013 Dec;14(8):593-601.

65. Thalange N, Bereket A, Larsen J, Hiort LC, Peterkova V. Insulin analogues in children with Type 1 diabetes: a 52-week randomized clinical trial. Diabet Med. 2013 Feb;30(2):216-25.

66. Pedersen-Bjergaard U, Kristensen PL, Beck-Nielsen H, Nørgaard K, Perrild H, Christiansen JS, Jensen T, Hougaard P, Parving HH, Thorsteinsson B, Tarnow L. Effect of insulin analogues on risk of severe hypoglycaemia in patients with type 1 diabetes prone to recurrent severe hypoglycaemia (HypoAna trial): a prospective, randomised, open-label, blinded-endpoint crossover trial. Lancet Diabetes Endocrinol. 2014 Jul;2(7):553-61. 
67. Bowker SL, Majumdar SR, Johnson JA. Systematic review of indicators and measurements used in controlled studies of quality improvement for type 2 diabetes. Can J Diabetes 2005;29(3):230-8.

68. Gabriel EE, Gilbert PB. Evaluating principal surrogate endpoints with time-toevent data accounting for time-varying treatment efficacy. Biostatistics. 2014 Apr;15(2):251-65. doi: 10.1093/biostatistics/kxt055. Epub 2013 Dec 13.

69. U.S. Department of Health and Human Services. Food and Drug Administration. Center for Drug Evaluation and Research (CDER). Guidance for Industry Diabetes Mellitus: Developing Drugs and Therapeutic Biologics for Treatment and Prevention. February 2008. Available:

http://www.fda.gov/downloads/Drugs/Guidances/ucm071624.pdf.

70. Rosenstock J, Park G, Zimmerman J, for the U.S. Insulin Glargine (HOE 901) Type 1 Diabetes Investigator Group. Basal insulin glargine (HOE 901) versus NPH insulin in patients with type 1 diabetes on multiple daily insulin regimens. Diabetes Care 2000;23:1137-42.

71. Pieber TR, Eugene-Jolchine I, Derobert E. Efficacy and safety of HOE 901 versus NPH insulin in patients with type 1 diabetes. Diabetes Care 2000;23:157-62.

72. American Diabetes Association Workgroup on Hypoglycemia. Defining and Reporting Hypoglycemia in Diabetes: A report from the American Diabetes Association Workgroup on Hypoglycemia. Diabetes Care 2005 May; 28(5): 12451249. https://doi.org/10.2337/diacare.28.5.1245

73. Ly TT, Maahs DM, Rewers A, Dunger D, Oduwole A, Jones TW; International Society for Pediatric and Adolescent Diabetes. ISPAD Clinical Practice Consensus Guidelines 2014. Assessment and management of hypoglycemia in children and adolescents with diabetes. Pediatr Diabetes. 2014 Sep;15 Suppl 20:180-92. doi: 10.1111/pedi.12174. Epub 2014 Jul 12.

74. Tsujino D, Nishimura R, Onda Y, Seo C, Ando K, Morimoto A, Utsunomiya K. The relationship between $\mathrm{HbA} 1 \mathrm{c}$ values and the occurrence of hypoglycemia as assessed by continuous glucose monitoring in patients with type 1 diabetes. Diabetology \& metabolic syndrome. 2016 Jul 29;8(1):53.

75. Guyatt G, Rennie D, Meade M, Cook D. Users' guide to the medical literature. JAMA Evidence.2nd edition, 2008. 
76. Nathan DM, DCCT/Edic Research Group. The diabetes control and complications trial/epidemiology of diabetes interventions and complications study at 30 years: overview. Diabetes care. 2014 Jan 1;37(1):9-16.

77. Dawoud D, Fenu E, Wonderling D, O'Mahony R, Pursey N, Cobb J, Amiel SA, Higgins B. Basal insulin regimens: Systematic review, network meta-analysis, and cost-utility analysis for the National Institute for Health and Care Excellence (NICE) Clinical guideline on type 1 diabetes mellitus in adults. Value in Health 2015; 18(7):A339.

78. Dżygało K, Golicki D, Kowalska A, Szypowska A. The beneficial effect of insulin degludec on nocturnal hypoglycaemia and insulin dose in type 1 diabetic patients: a systematic review and meta-analysis of randomised trials. Acta diabetologica. 2015 Apr 1;52(2):231-8.

79. Esposito K, Chiodini P, Capuano A, Petrizzo M, Improta MR, Giugliano D. Basal supplementation of insulin lispro protamine suspension versus insulin glargine and detemir for type 2 diabetes meta-analysis of randomized controlled trials. Diabetes Care. 2012 Dec 1;35(12):2698-705.

80. Bergenstal RM, Lincoff AM, Rodriguez A, Chen L, Qu Y, Prince MJ, Hoogwerf BJ. No difference in Major Adverse Cardiovascular Events (MACE plus) with Basal Insulin peglispro (BIL) vs comparator insulins in patients with type 1 or type 2 diabetes. Diabetologia 2015 Sep 1; 58:S65-S66.

81. Goldman J, White JR. New insulin glargine $300 \mathrm{U} / \mathrm{mL}$ for the treatment of type 1 and type 2 diabetes mellitus. Annals of Pharmacotherapy. 2015 Oct 1;49(10):115361.

82. Rys P, Wojciechowski P, Rogoz-Sitek A, Niesyczyński G, Lis J, Syta A, Malecki MT. Systematic review and meta-analysis of randomized clinical trials comparing efficacy and safety outcomes of insulin glargine with NPH insulin, premixed insulin preparations or with insulin detemir in type 2 diabetes mellitus. Acta diabetologica. 2015 Aug 1;52(4):649-62.

83. Linnebjerg H, Lam EC, Seger ME, Coutant D, Chua L, Chong CL, Ferreira MM, Soon D, Zhang X. Comparison of the pharmacokinetics and pharmacodynamics of LY2963016 insulin glargine and EU-and US-approved versions of Lantus insulin glargine in healthy subjects: three randomized euglycemic clamp studies. Diabetes Care 2015 Dec 1;38(12):2226-33. 
84. Heinemann L. Biosimilar Insulin and Costs What Can We Expect? Journal of diabetes science and technology. 2015 Sep 8:1932296815605337.

85. Life Sciences \& Transformational Health. Biosimilars Insulin Market: Global Industry Analysis and Forecast 2016 - 2024. Report code: PMRREP11674. Work in progress. March 2017. Available: http://www.persistencemarketresearch.com/marketresearch/biosimilars-insulin-market.asp

86. Rotenstein LS, Ran N, Shivers JP, Yarchoan M, Close Kl. Opportunities and challenges for biosimilars: what's on the horizon in the global insulin market? Clin. Diabetes 2012;30:138-150.

87. Krentz AJ, Hompesch M. Biosimilar insulins: current and future perspectives. Diabetes Manag. 2015;5(6):405-409. 


\section{IMPACTO ORÇAMENTÁRIO DAS INSULINAS ANÁLOGAS DE LONGA DURAÇÃO: O CASO DO BRASIL}

\subsection{ABSTRACT ${ }^{1}$}

Background: Long-acting insulin analogues for type 1 diabetes (T1D) treatment have been available on the Brazilian market since 2002. However, the population cannot access the analogues through the public health system.

Objective: To estimate the incremental budget impact of long-acting insulin analogues coverage for T1D patients in the Brazilian public health system compared to NPH insulin.

Methods: We performed a budget impact analysis of a five-year period. The eligible population was projected using epidemiological data from the International Diabetes Federation estimates for patients between 0-14 and 20-79 years old. The prevalence of T1D was estimated in children, and the same proportion was applied to the 15-19year-old group due to a gap in epidemiological information. We considered 4,944 new cases per year and a 34.61/100,000 inhabitants mortality rate. Market share for long-acting insulin analogues was assumed as $20 \%$ in the first year, reaching $40 \%$ in the fifth year. The mean daily dose was taken from clinical trials. We calculated the bargaining power of the Ministry of Health by dividing the price paid for human insulin in the last purchase by the average regulated price. We performed univariate sensitivity analyses.

Results: The incremental budget impact of long-acting insulin analogues was $\mathrm{R} \$$ 114.3 million in the first year, and reached $\mathrm{R} \$ 235$ million in the fifth year. The total incremental budget impact was $\mathrm{R} \$ 871.4$ million over the five-year period. The sensitivity analysis showed that the percentage of T1D among diabetic adults and the insulin analogue price were the main factors that affected the budget impact.

Conclusions: The cost of the first year of long-acting insulin analogue coverage would correspond to $0.03 \%$ of total public health expenditure. The main advantage of this study is that it identifies potential bargaining power because it features more

\footnotetext{
${ }^{1}$ Laranjeira FO, Silva EN, Pereira MG. Budget Impact of Long-Acting Insulin Analogues: The Case in Brazil. PLoS ONE 2016; 11(12): e0167039. doi:10.1371/journal.pone.0167039.
} 
realistic profiles of resource usage, once centralized purchasing is established as an economically sustainable strategy. Clinical guidelines restricting the use of insulin analogues would make the decision towards insulin analogue coverage more affordable. 


\subsection{INTRODUCTION}

The prevalence of diabetes is estimated to be $8.3 \%$ worldwide, affecting approximately 382 million people, of whom 5 to $10 \%$ have type 1 of the disease (1). The last major pharmacological innovation for these patients took place approximately 20 years ago with the emergence of insulin analogues (2). Although other insulins have been introduced over time (most recently the long-acting insulin analogues with flatter pharmacodynamic profile and the faster-acting insulin analogues for boluses), all pharmacological innovations for type 1 diabetes (T1D) continue in the same pattern as the analogues. Evidence suggests that insulin analogues show greater efficacy, cause fewer hypoglycemia episodes and promote a better quality of life than human insulin (3-5). However, their higher cost has created barriers to accessing these technologies in health systems (6), particularly universal systems.

Insulin significantly contributes to the cost associated with diabetes, representing $24(7)$ to $36 \%$ (8) of the treatment cost. The high cost has generated extensive discussion between parties favoring or opposing insulin analogues coverage $(9,10)$. In certain high-income countries, such as in Canada, the United Kingdom, Australia and France, individuals with T1D have access to insulin analogues $(6,11,12)$, but under strict prescription criteria and only those in groups for which the analogues are cost-effective (13).

Brazil has the fourth largest number of diabetes patients worldwide, and type 1 affects approximately $0.31 \%$ of its population $(1,14)$. In a 2010 study, glycemic control was unsatisfactory in $87 \%$ of these patients (A1C > 7\%) (15). For T1D treatment, long-acting insulin analogues have been available on the Brazilian market since 2002. However, analogues are not accessible to the whole population through the national public health system. In 2014, the Brazilian Ministry of Health declined to provide rapid- and long-acting insulin analogues at the national level (16), based on two criteria: huge budget impact, due to high cost of insulin analogues, and the lack of evidence on efficacy.

The aim of this study is to estimate the incremental budget impact of longacting insulin analogue coverage for T1D patients on the Brazilian public health system compared with current treatment provided by the public health system (NPH 
as basal insulin). This information may contribute to future decision-making processes not only in Brazil but also other developing countries that do not offer this type of insulin to their population.

\subsection{METHODS}

We carried out a budget impact analysis, in which we evaluated the affordability of offering long-acting insulin analogues (glargine or detemir) to T1D patients in the Brazilian public health system. A five-year time horizon was used disregarding conventional economic adjustments (discount rate and inflation) in accordance with recommendations from international methodological guidelines for budget impact analyses (17-19). The calculations were performed using TreeAge ${ }^{\circledR}$ Pro 2015 software.

It is worth noting that the treatment of T1D patients often combines two types of insulin: long-acting (basal profile) and rapid-acting (bolus profile). Although they are often used together by patients, international agencies have assessed these two types of insulin separately, for example: the National Institute for Health and Care Excellence (NICE) in the UK (20), the National Committee for Technology Incorporation (CONITEC) in Brazil (16), and the Canadian Agency for Drugs and Technologies in Health (CADTH) in Canada $(21,22)$. On this basis, we only included long-acting insulin in this study.

\subsubsection{Scenarios}

The reference scenario was availability of NPH insulin only (currently available in public health system) as basal insulin for T1D patients. The alternative scenario was coverage of long-acting insulin analogues, glargine or detemir, to partially replace the NPH human insulin. We assumed that the insulin analogues exhibit similar efficacy and safety $(3,4)$. We did not include the insulin analogue degludec in 
the analysis because we have not identified any studies which compared degludec with NPH insulin.

\subsubsection{Target Population}

The target population was calculated using epidemiological studies. Our starting point was the International Diabetes Federation (IDF) estimate of 11.6 million diabetic people aged between 20 and 79 years in Brazil (1) and we used 5\% as the percentage of T1D among adults with diabetes (14). We included 31,100 diabetic people between 0 and 14 years old (14) (IDF estimate for children) in the model. Additionally, the prevalence was calculated for the 0-14-year-old age group by dividing the total number of T1D patients by the total 0-14-year-old population based on information from the Brazilian Institute of Geography and Statistics (23). We reached a 0.654/1000 child prevalence. Subsequently, the same estimated prevalence was applied to the 15-19-year-old age group by multiplying the prevalence by the total 15-19-year-old population (23). The target population was the total number of people estimated with T1D, which was obtained by summing the prevalence in the 0-14-year-old, 15-19-year-old and 20-79-year-old age groups.

We assumed 4,944 new cases per year (14) in the child age group to calculate the target population growth from the second year of the analysis onward. For this same period of analysis, we also used a T1D mortality rate of $34.61 / 100,000$ inhabitants (24), calculated from Brazilian historical series published in 2012, which only included the T1D adult population.

\subsubsection{Costs}

We considered direct costs associated with purchasing insulin over five years from the Brazilian public health system perspective.

Among the insulins analysed in this study, the Brazilian Ministry of Health only purchases NPH insulin, for which it has centralized purchasing. The Official Gazette, 
the official media vehicle of the Brazilian government, was used as the source for the values and quantities of the Ministry of Health's most recent $10 \mathrm{ml}$ vials purchase (25).

To estimate the price that the Ministry of Health would pay to acquire long-acting insulin analogues (glargine and detemir), we simulated centralized purchasing (single buyer) gains based on the pattern verified with NPH. Thus, the ratio of the value paid by the Ministry of Health (centralized purchasing) and the regulated value (maximum selling price to the government (26)) was calculated. We calculated a 0.25 ratio; i.e., the value paid for $\mathrm{NPH}$ was $25 \%$ of the regulated value, representing a government bargaining power of $75 \%$. We assumed that, for long-acting insulin analogues, the Ministry of Health would have $50 \%$ of the NPH bargaining power; i.e., the acquired value would be $62.5 \%$ of the regulated glargine and detemir values. For the sensitivity analysis, the lower limit was $100 \%$ of the bargaining power, and the upper limit was the regulated price ( $0 \%$ of the bargaining power).

To calculate the mean daily insulin dose, we used the mean dose from clinical trials that compared long-acting insulin analogues with NPH in children and adults. We used studies with more participants and adequate information on the mean dose. The insulin price was calculated per $\mathrm{ml}$, and, at the end of the formula, the units were adjusted from IU to $\mathrm{ml}$, and the mean dose was adjusted from daily to annual.

We used the mean daily dose from Home et al. (27) for adults over 19 years old and from Schober et al. (28) for children and adolescents under 19 years old (Table 3.1). Information on variations in value for both studies was poor; the amplitude was obtained using the minimum and maximum values and the difference between the baseline and end of the study. Thus, we used a 0.20 (29) standard deviation as the variation for all individuals.

Table 3.1 - Average daily dose used per age group

\begin{tabular}{l|c|c|c|c}
\hline \multicolumn{1}{c|}{ AGE GROUPS } & \multicolumn{4}{|c}{ DOSE IU/DAY } \\
\cline { 2 - 5 } & NPH & SD & ANALOGUE & SD \\
\hline Children & 21.10 & \pm 0.20 & 18.20 & \pm 0.20 \\
Adolescents & 21.10 & \pm 0.20 & 18.20 & \pm 0.20 \\
Adults & 21.00 & \pm 0.20 & 20.00 & \pm 0.20 \\
\hline
\end{tabular}

IU: international units. NPH: Neutral Protamine Hagedorn insulin. SD: standard deviation. 
The value derived from the last Ministry of Health NPH purchase was $R \$ 0.88$ per $\mathrm{ml}(25)$. The long-acting insulin analogue price was $\mathrm{R} \$ 13.60 \mathrm{per} \mathrm{ml}$. Thus, based on the mean daily dose per age group, we calculated a total annual cost of $R \$ 69.68$ per child or adolescent who uses NPH insulin and $\mathrm{R} \$ 902.56$ per child or adolescent who uses a long-acting insulin analogue. For adults, the annual values were $R \$$ 67.36 for $\mathrm{NPH}$ and $\mathrm{R} \$ 991.84$ for analogues.

\subsubsection{Diffusion Rate}

We assumed a market share of $20 \%$ for long-acting insulin analogues in the first year, which increased 5 percentage points in the following periods until reaching $40 \%$ in the fifth year. This assumption was based on published and unpublished papers $(30,31)$ which described utilization rates of long-acting insulin analogues between $14 \%$ and $25 \%$.

\subsubsection{Sensitivity Analysis}

We performed univariate sensitivity analyses through a tornado diagram, using confidence intervals, standard deviation or other types of measure of variation. The variation in parameters used for the sensitivity analysis was as follows.

- Percentage of T1D among total adult population with diabetes: 3 to $10 \%$

- T1D mortality rate in adults aged 19 years and over: 16.68 - 54.38/100,000 adults (24)

- Incidence in the population up to 14 years old: 8.76 - 18.49 per 100,000 children (32)

- Mean dose: \pm 0.20 IU per day (29)

- NPH insulin price: $\mathrm{R} \$ 0.60-1.16$ per $\mathrm{ml}$

- Insulin analogues price: $\mathrm{R} \$ 5.44-21.72$ per $\mathrm{ml}$

- Market share:

○ Year 1: 10\% - 50\% 

○ Year 2: $15 \%-60 \%$
- Year 3: $20 \%-70 \%$
- Year 4: 25\%-80\%
○ Year 5: $30 \%-80 \%$

\subsection{RESULTS}

\subsubsection{Target Population}

Figure 3.1 shows the dynamic population model assumed in our study, which projected the new cases, prevalence and mortality related to T1D. In the first year, we estimated 621,945 individuals had T1D, mainly adults (93\%), followed by $6 \%$ children and $1 \%$ adolescents.

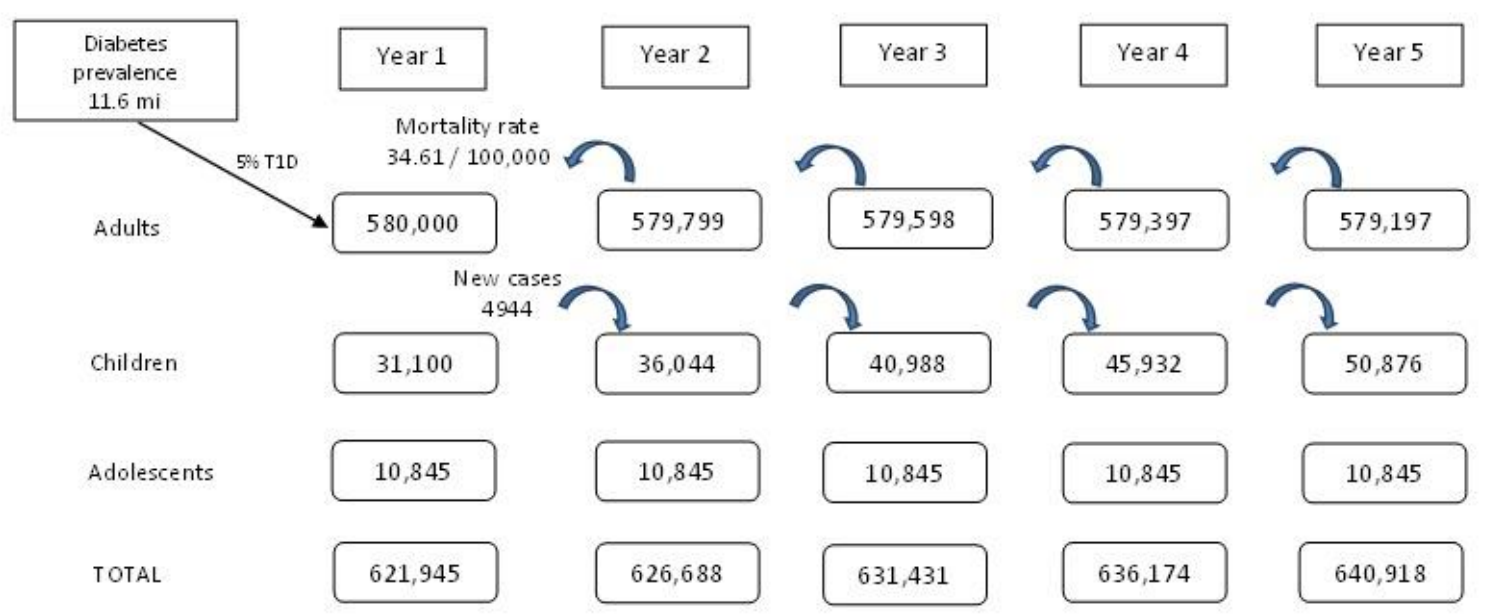

Figure 3.1 Model population dynamics for the budget impact analysis 


\subsubsection{Incremental Budget Impact Analysis}

The cost of the reference scenario (100\% NPH insulin) was $\mathrm{R} \$ 41,9$ million in 2015 , while the cost of the alternative scenario $(80 \% \mathrm{NPH}+20 \%$ insulin analogues) was $R \$ 156,3$ million in the same period, which results in an incremental budget impact of $R \$ 114,3$ million. As long as the proportion of insulin analogues increases over the course of the time horizon in the alternative scenario, the incremental budget gets bigger. For example, the incremental cost was $R \$ 235$ million in 2019. For the five-year period-analysis, the total incremental budget impact was $R \$ 871,440,000.00$ (Table 3.2).

Table 3.2 - Budget impact by scenario and incremental cost by year and for 5 years period (in $\mathrm{R} \$ 1,000$ )

\begin{tabular}{|c|c|c|c|}
\hline \multicolumn{4}{|c|}{ Year 1 - 2015} \\
\hline Scenario & Market share & Cost & Incremental cost \\
\hline Alternative & $80 \% \mathrm{NPH}+20 \%$ analogue & 156,316 & 114,352 \\
\hline Reference & $100 \% \mathrm{NPH}$ & 41,964 & - \\
\hline \multicolumn{4}{|c|}{ Year 2 - 2016} \\
\hline Scenario & Market share & Cost & Incremental cost \\
\hline Alternative & $75 \% \mathrm{NPH}+25 \%$ analogue & 186,212 & 143,924 \\
\hline Reference & $100 \% \mathrm{NPH}$ & 42,288 & \\
\hline \multicolumn{4}{|c|}{ Year 3 - 2017} \\
\hline Scenario & Market share & Cost & Incremental cost \\
\hline Alternative & $70 \% \mathrm{NPH}+30 \%$ analogue & 216,500 & 173,892 \\
\hline Reference & $100 \% \mathrm{NPH}$ & 42,608 & \\
\hline \multicolumn{4}{|c|}{ Year 4 - 2018} \\
\hline Scenario & Market share & Cost & Incremental cost \\
\hline Alternative & $65 \% \mathrm{NPH}+35 \%$ analogue & 247,188 & 204,260 \\
\hline Reference & $100 \% \mathrm{NPH}$ & 42,928 & 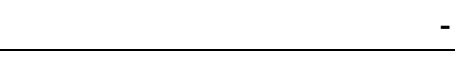 \\
\hline \multicolumn{4}{|c|}{ Year 5 - 2019} \\
\hline Scenario & Market share & Cost & Incremental cost \\
\hline Alternative & $60 \% \mathrm{NPH}+40 \%$ analogue & 278,268 & 235,016 \\
\hline Reference & $100 \% \mathrm{NPH}$ & 43,252 & - \\
\hline \multicolumn{4}{|c|}{ TOTAL } \\
\hline Scenario & & Cost & Incremental cost \\
\hline Alternative & & $1,084,480$ & 871,440 \\
\hline Reference & & 213,040 & - \\
\hline
\end{tabular}




\subsubsection{Sensitivity Analysis}

Based on the tornado diagram results, the two variables that most affected the budget were the percentage of T1D in the total adult diabetic population and the insulin analogue price, representing $54.19 \%$ and $34.68 \%$ of the total uncertainty, respectively. Market share played a small role on the sensitivity analysis, representing between 1.45\% (Year 1) and 2.85\% (Year 4) of total uncertainty. The remaining variables marginally affected the uncertainty (i.e., they had limited influence on the incremental budget impact) (Figure 2).

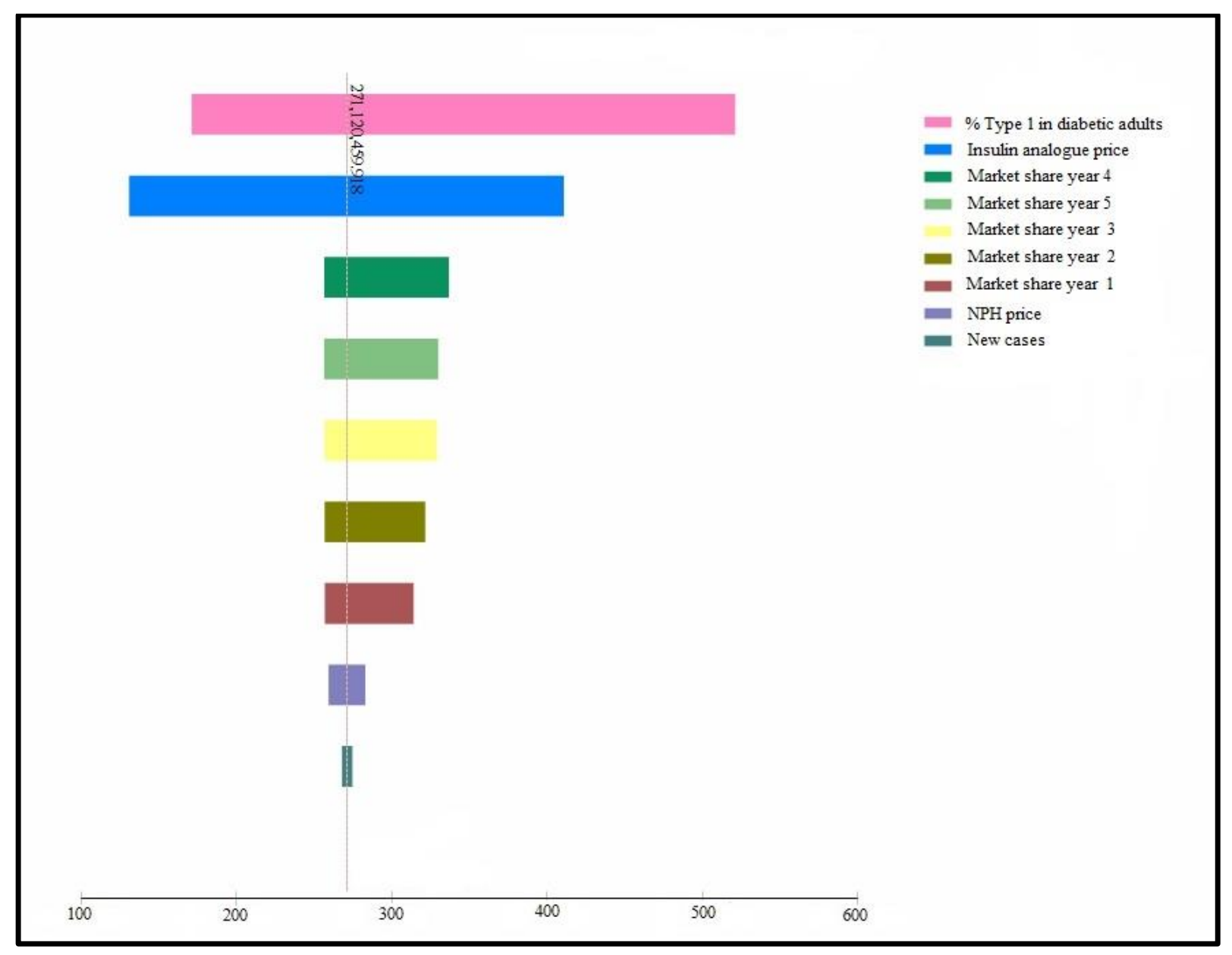

Figure 3.2 Variation of incremental budget impact according to changes on the assumptions of the model 
We ran a univariate sensitivity analysis on the two parameters that had the largest impact on the incremental analysis. For the long-acting insulin analogue price, at the lower limit, the Brazilian Ministry of Health would obtain the same discount for insulin analogues as currently used for NPH insulin. Under this assumption, the incremental budget impact would substantially decrease by more than $40 \%$ ( $R \$$ 871.4 million vs. $\mathrm{R} \$ 523.2$ million) (Figure 3).

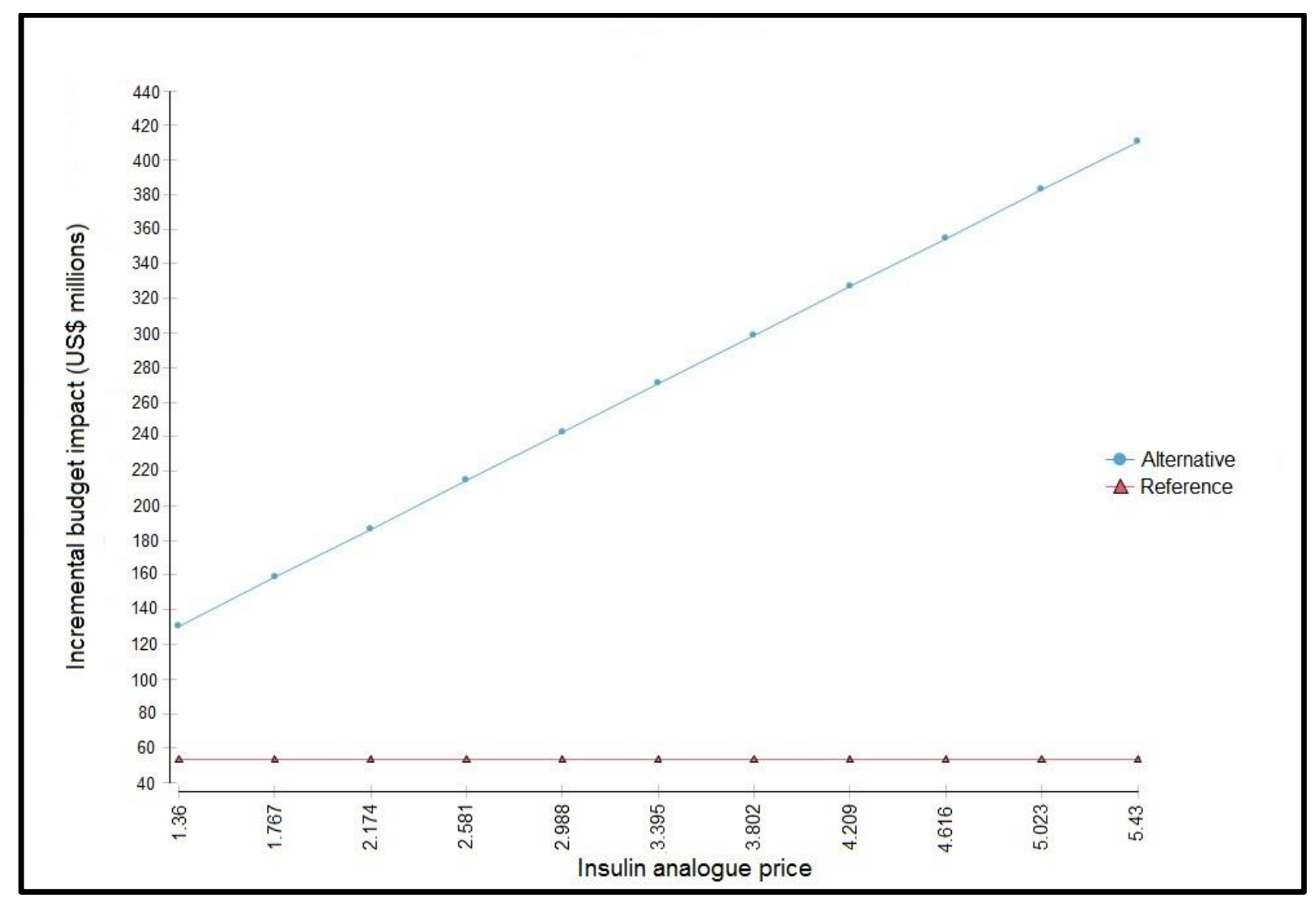

Figure 3.3 Budget impact evolution due to variation of insulin analogues price

The percentage of T1D among diabetic adults affected both scenarios but exerted a greater effect on the alternative one. Using $3 \%$ of $\mathrm{T} 1 \mathrm{D}$ in total diabetic adults, the incremental budget impact decreases from $R \$ 871.4$ million to $R \$ 684.8$ million in five years. However, by using $10 \%$ of T1D in diabetic adults, the incremental impact reaches $\mathrm{R} \$ 2.08$ billion over the same period. 


\subsection{DISCUSSION}

Our study brings new evidence to support decision-making on the reimbursement of long-acting insulin analogues glargine and detemir for the Brazilian public health system, taking into consideration the bargaining power of centralized purchases at the national level. The results show an increment of $R \$ 871.4$ million in the public budget over five years. For the first year of providing long-acting insulin analogues, the cost would correspond to $0.05 \%$ of the total Brazilian public health expenditure (33). More specifically, considering the 2015 budget for the Specialized Component of the Pharmaceutical Assistance (34) ( $\mathrm{R} \$ 5$ billion), in the first year, long-acting insulin analogues would represent $2.51 \%$ of the budget; in the fifth year, this percentage would increase to $5.8 \%$.

In 2014, the Brazilian Ministry of Health carried out a budget impact analysis of introducing insulin analogues into the public health system, which estimated an impact of $R \$ 2.48$ billion (16), which is 2.84 times greater than our estimate. The difference arises from methodological differences, particularly for the mean dose (which was greater than in our analysis), insulin cost measurements (the price of long-acting insulin analogues was 38\% greater than in our study) and the market share (the Brazilian Ministry of Health analysis included $100 \%$ of the target population).

Our study used the mean daily dose from clinical trials $(27,28)$, which varied by age group. Observational studies, including Brazilian studies $(7,15,35)$, found different doses among the population. However, we used information from studies with better methodological quality.

Our study is innovative because we introduced bargaining power into the model. The Brazilian Ministry of Health has used the centralized purchasing modality since 2009 (36,37). Centralized purchasing increases the scale and provides a greater margin for price negotiation (38). For NPH human insulin, the maximum regulated price was reduced by $75 \%$. For the baseline, we adopted a conservative premise and assumed that, upon introducing long-acting insulin analogues into the system, the Brazilian Ministry of Health would receive a $37.5 \%$ discount, which is half of its bargaining power for NPH. Certain studies indicate that centralized purchasing reduces the price by, on average, 30 to $50 \%$ of the decentralized purchasing value 
(39-41) Another study shows a need to decrease the price of analogues so that they become more attractive to the health system (42). Therefore, it is important that insulin analogues are purchased nationally for better bargaining power compared with local negotiations.

For the market share, the need of the Brazilian T1D population for insulin analogues is unknown. Due to the lack of diffusion statistics, we used a conservative market entry profile, which peaked at $40 \%$ of the target population in five years. Aggressive market shares, such as $100 \%$ of the target population, would not be considered due to rational indication restrictions proposed by national and international guidelines $(6,13,43,44,45)$. These indication restrictions follow a global trend concerning similar restrictions proposed by other countries with public health systems.

Notably, Poland provides long-acting insulin analogues, but only for patients with severe hypoglycemia episodes. The coverage was the result of a therapeutic program based on the treatment's success at decreasing hypoglycemia episodes after six months. In Poland, the success rate was $25 \%$ among T1D patients (31); thus, the coverage was affordable. If the same access strategy were applied in Brazil, then the incremental budget impact would substantially decrease.

In Brazil, guidelines from the Ministry of Health have been restricting indications to treatment. There are some successful examples of the strategy, such as the rheumatoid arthritis, for which biological drugs are only provided for patients considered to be at a serious stage of the condition and who have been tested for all other disease-modifying-antirheumatic-drugs (DMARDs) (46). Another example is multiple sclerosis, a disease for which the guideline is divided into three treatment lines (47). Several kinds of cancer have clinical guidelines also structured in treatment lines that can limit the use of high-cost drugs to those in the population who would benefit most from this type of drug (48).

Although the public health system does not provide analogue insulin the national level, there are some Brazilian states that already provide it at the local level. In these states, there are clinical guidelines that define the inclusion criteria for insulin analogue use, which are people: i) who have previously-diagnosed T1D; ii) have persistent bad glycemic control, after use of multiple daily injections with human insulin, documented by $\mathrm{A} 1 \mathrm{C}$ tests ( 3 in the last 12 months) plus a clinician evaluation, detailing previous treatment algorithms with dosage and type of insulin used; iii) who 
have severe hypoglycemia $(<50 \mathrm{mg} / \mathrm{dl}$ ), regarding 2 or 3 episodes proven by laboratory tests or emergency reports on two different occasions, and iv) unawareness hypoglycemia. In these guidelines, bad glycemic control is defined as: A1C with 2 points above the superior limit of test (49).

It is worth noting that as we did not find Brazilian evidence that insulin analogues reduce the need for health resources, such as hospitalizations or complications, compared with $\mathrm{NPH}$, we did not include them in our study. However, there is plenty of evidence on this issue in the international literature (50). For example, evidence has shown that compared with $\mathrm{NPH}$, insulin analogues decreases the risk of severe hypoglycemia episodes by $38 \%$ (OR $0.62,95 \% \mathrm{Cl} 0.42-0.91$ ) (4), the risk of nocturnal hypoglycemia episodes by $46 \%(p=0.04)(51)$, the risk of hospitalization due to the first severe hypoglycemic event by $21.7 \%$ (95\% Cl 9.6$32.1 \%, p<0.001)(52)$, the risk of hypoglycemic coma recurrence by $36.3 \%(95 \% \mathrm{Cl}$ 8.9-55.5\%, $p=0.014$ ) (52), hospitalizations by $49 \%$ (53), the incidence of macrovascular complications by $48 \%$ (54), and annual costs (55).

Some limitations of our study should be acknowledged. First, we did not consider the indirect effect of insulin analogues on health services. According to the international literature, insulin analogues tend to decrease the need for health resources compared with NPH. Second, we only included long-acting insulin in our study, although T1D patients often used long-action insulin combined with rapidacting insulin. A recent study carried out by the Brazilian Society of Diabetes estimated the budget impact of rapid-acting insulin analogues on the public health system would range between $R \$ 242$ million and $R \$ 404$ million in five years.

\subsection{CONCLUSION}

In Brazil, states and municipalities have the autonomy to take decisions, including issues related to health technologies coverage. Thus, some Brazilian states already provide insulin analogues. However, based on our results, insulin analogue coverage should be part of a national policy because national price negotiation could achieve more affordable prices for the health system as a whole. In this context, clinical guidelines must effectively identify patients with a greater potential to benefit 
from insulin analogues with clear criteria for inclusion and maintenance in the program. Our analysis was conservative because we did not use the full potential of bargaining power and because we used a broad market share. New opportunities for research emerge from these results, notably on the prevalence of diabetes, the need for insulin analogues and use of real-world data for a new budget impact model. 


\section{REFERENCES}

1. International Diabetes Federation. IDF Diabetes Atlas. 2015. Available: www.idf.org/diabetesatlas.

2. Betz JL. Fast-acting human insulin analogues: a promising innovation in diabetes care. Diabetes Educ. 1995;21: 195, 197-198, 200.

3. Monami M, Marchionni N, Mannucci E. Long-acting insulin analogues vs. NPH human insulin in type 1 diabetes. A meta-analysis. Diabetes Obes Metab. 2009;11: 372-378.

4. Tricco AC, Ashoor HM, Antony J, Beyene J, Veroniki AA, Isaranuwatchai W, Harrington A, Wilson C, Tsouros S, Soobiah C, Catherine HY. Safety, effectiveness, and cost effectiveness of long acting versus intermediate acting insulin for patients with type 1 diabetes: systematic review and network meta-analysis. BMJ. 2014;349:95459.

5. Hartman I. Insulin analogues: impact on treatment success, satisfaction, quality of life, and adherence. Clin Med Res. 2008;6: 54-67.

6. Orlewska E, Gulácsi L. PDB66 Paying for costly pharmaceuticals—reimbursement status of long-acting insulin analogues in selected developed countries. Value in Health. 2009;12: A414.

7. Cobas RA, Ferraz MB, Matheus AS, Tannus LRM, Negrato CA, de Araujo LA, et al. The cost of type 1 diabetes: a nationwide multicentre study in Brazil. Bull World Health Organ. 2013;91: 434-440.

8. Tao B, Pietropaolo M, Atkinson M, Schatz D, Taylor D. Estimating the cost of type 1 diabetes in the U.S.: a propensity score matching method. PLoS One. 2010;5: e11501.

9. Holden SE, Currie CJ. Do the benefits of analogue insulins justify their costs? Diabetes Manage. 2012;2: 173-175.

10. Grunberger G. Insulin analogues-are they worth it? Yes! Diabetes Care. 2014;37: 1767-1770.

11. Drummond M, Jonsson B, Rutten F, Stargardt T. Reimbursement of pharmaceuticals: reference pricing versus health technology assessment. Eur $\mathrm{J}$ Health Econ. 2011;12: 263-271. 
12. Holden SE, Poole CD, Morgan CL, Currie CJ. Evaluation of the incremental cost to the National Health Service of prescribing analogue insulin. BMJ Open. 2011;1: e000258.

13. Palmer AJ, Valentine WJ, Ray JA, Foos V, Lurati F, Smith I, et al. An economic assessment of analogue basal-bolus insulin versus human basal-bolus insulin in subjects with type 1 diabetes in the UK. Curr Med Res Opin. 2007;23: 895-901. 14. Patterson C, Guariguata L, Dahlquist G, Soltész G, Ogle G, Silink M. Diabetes in the young-a global view and worldwide estimates of numbers of children with type 1 diabetes. Diabetes Res Clin Pract. 2013;103: 161-175.

15. Gomes MB, Coral M, Cobas RA, Dib SA, Canani LH, Nery M, et al. Prevalence of adults with type 1 diabetes who meet the goals of care in daily clinical practice: a nationwide multicenter study in Brazil. Diabetes Res Clin Pract. 2012;97: 63-70. 16. Ministério da Saúde. Insulinas análogas para diabetes mellitus tipo 1. Relatório de recomendação da Comissão Nacional de Incorporação de Tecnologias no SUS CONITEC - 114. 2015. Available:

http://conitec.gov.br/images/Relatorios/2014/Insulinas-tipol-FINAL.pdf.

17. Ferreira-Da-Silva AL, Ribeiro RA, Santos VCC, Elias FTS, d'Oliveira ALP, Polanczyk CA. Guidelines for budget impact analysis of health technologies in Brazil. Cadernos de Saúde Pública. 2012;28: 1223-1238.

18. Mauskopf JA, Sullivan SD, Annemans L, Caro J, Mullins CD, Nuijten M, et al. Principles of good practice for budget impact analysis: report of the ISPOR task force on good research practices_budget impact analysis. Value Health. 2007;10: 336347.

19. Sullivan SD, Mauskopf JA, Augustovski F, Caro J, Lee KM, Minchin M, et al. Budget impact analysis-principles of good practice: report of the ISPOR 2012 budget impact analysis good practice II task force. Value Health. 2014;17: 5-14.

20. National Institute for Clinical Excellence. Guidance on the use of long-acting insulin analogues for the treatment of diabetes: insulin glargine. Technology Appraisal Guidance. 2002 Dec;53. Available: https://www.nice.org.uk/guidance/ta53. 21. Tran K, Banerjee S, Li H, Cimon K, Daneman D, Simpson SH, Campbell K. Long-acting insulin analogues for diabetes mellitus: meta-analysis of clinical outcomes and assessment of cost-effectiveness. Technology report. 2007(92). Available: https://www.cadth.ca/sites/default/files/pdf/341b Long-actinginsulin tr e.pdf. 
22. Banerjee S, Tran K, Li H, Cimon K, Daneman D, Simpson S, Campbell K. Shortacting insulin analogues for diabetes mellitus: meta-analysis of clinical outcomes and assessment of cost-effectiveness. Technology Report. 2007(87). Available:

https://www.cadth.ca/sites/default/files/pdf/341A Insulin tr e.pdf.

23. Instituto Brasileiro de Geografia e Estatística. Household Budget Survey 20082009. Anthropometry and nutritional status of children, teenagers and adults in Brazil. 2015. Available:

http://www.ibge.gov.br/home/estatistica/populacao/condicaodevida/pof/2008 2009 e ncaa/pof 20082009 encaa.pdf.

24. Mattos PE, Luz LL, Santiago LM, Mattos IE. Trends in mortality of diabetes mellitus patients in Brazilian capitals, 1980-2007. Arquivo Brasileiro de Endocrinologia Metabolica. 2012 Feb;56(1):39-46.

25. Diário Oficial da União. Seção 3, no 249. 2014. Available:

http://pesquisa.in.gov.br/imprensa/jsp/visualiza/index.jsp?jornal=3\&pagina=158\&data $=24 / 12 / 2014$.

26. National Health Surveillance Agency. Câmara de regulação do mercado de medicamento. List of maximum selling price to the government. 2015. Available: http://portal.anvisa.gov.br/wps/content/Anvisa \pm Portal/Anvisa/Servicos/Consulta $\pm a \pm B a$ nco \pm de \pm Dados/Medicamentos.

27. Home PD, Rosskamp R, Forjanic-Klapproth J, Dressler A, European Insulin Glargine Study Group. A randomized multicentre trial of insulin glargine compared with NPH insulin in people with type 1 diabetes. Diabetes Metab Res Rev. 2005;21: 545-553.

28. Schober E, Schoenle E, van Dyk J, Wernicke-Panten K. Comparative trial between insulin glargine and NPH insulin in children and adolescents with type 1 diabetes. Diabetes Care. 2001;24: 2005-2006.

29. Holcombe JH, Zalani S, Arora VK, Mast CJ. Comparison of insulin lispro with regular human insulin for the treatment of type 1 diabetes in adolescents. Clin Ther. 2002;24: 629-638.

30. Leite EB, Pedrosa HC, Casulari LA. Results of glycated hemoglobin during treatment with insulin analogues dispensed in the public health system of Federal District in Brazil. Diabetol Metab Syndr. 2015;18:7-66.

31. Orlewska E, Gulacsi L. PDB23 Budget impact analysis of the reimbursement of long-acting insulin analogues in Poland. Value in Health. 2011;14:A475. 
32. Negrato CA, Dias JP, Teixeira MF, Dias A, Salgado MH, Lauris JR, et al. Temporal trends in incidence of type 1 diabetes between 1986 and 2006 in Brazil. J Endocrinol Invest. 2010;33: 373-377.

33. World Health Organization. WHO Global Health Expenditure Atlas. September 2014. ISBN 978924150444 7. Printed in Switzerland. Available:

http://www.who.int/health-accounts/atlas2014.pdf.

34. Ministério da Saúde. Secretaria de Ciência, Tecnologia e Insumos Estratégicos. Departamento de Assistência Farmacêutica e Insumos Estratégicos. Specialized Component of Pharmaceutical Care: innovation for the guarantee of access to medicines in the Brazilian Health System (SUS/Brazil).- Brasília: Ministério da Saúde, 2014. Available:

http://www.farmacia.pe.gov.br/sites/farmacia.saude.pe.gov.br/files/componente espe cializado da assistencia farmaceutica.pdf

35. Gomes MB, Negrato CA, Cobas R, Tannus LR, Goncalves PR, da Silva PC, et al. Determinants of intensive insulin therapeutic regimens in patients with type 1 diabetes: data from a nationwide multicenter survey in Brazil. Diabetol Metab Syndr. $2014 ; 6: 67$.

36. Ministério da Saúde. Portaria no 2.981, November 26/2009. Approves the specialized component of pharmaceutical care, Seção 1. Brasilia, DF: Diario Oficial da Uniao; 2009. pp. 71. Available:

http://bvsms.saude.gov.br/bvs/saudelegis/gm/2009/prt2981 26112009 rep.html 37. Vieira FS, Zucchi P. Financing of pharmaceutical services in Brazilian public health system. Saude Soc. 2013;22: 73-84.

38. Chalkidou K, Anderson GF, Faden R. Eliminating drug price differentials across government programmes in the USA. Health Economics, Policy and Law, Cambridge, 2010;4: 1-22.

39. Ferraes AMB, Cordoni Jr L. Consortium of medicines in Parana: analysis of coverage and cost. RAP Rio de Janeiro May. 2007;41: 475-486. Avaiable: http://www.scielo.br/pdf/rap/v41n3/a05v41n3.pdf

40. Amaral SM, Blatt CR. Municipal consortia for medicine procurement: impact on the stock-out and budget. Rev Saude Publica. 2011;45: 799-801.

41. Zangheline F, Silva AS, Filho JAR. The economic importance about centralized purchasing of tumor necrosis factor-alpha inhibitors in Pernambuco. Rev Eletron Farm. 2014;XI:15-24. 
42. de Souza ALC, Acurcio FA, Júnior AAG, do Nascimento RCRM, Godman B, Diniz LM. Insulin glargine in a Brazilian State: should the Government disinvest? An assessment based on a systematic review. Appl Health Econ Health Policy. 2014;12: 19-32.

43. Araújo S, Araújo A, Gerhardt N, Ortiz CDVA. Diretrizes da sociedade brasileira de diabetes: 2013-2014 (Guidelines of Brazilian society of diabetes) /Sociedade Brasileira de Diabetes. Organização José Egídio Paulo de Oliveira, Sérgio Vencio, AC Farmacêutica, Sao Paulo. 2014. Avaiable:

http://www.diabetes.org.br/images/pdf/diretrizes-sbd.pdf

44. National Institute for Health and Care Excellence. Type 1 diabetes: diagnosis and management of type 1 diabetes in children, young people and adults. NICE clinical guideline 15. 2015. Available: http://www.nice.org.uk/guidance/cg15.

45. Chiang JL, Kirkman MS, Laffel LM, Peters AL. Type 1 diabetes through the life span: a position statement of the American Diabetes Association. Diabetes Care. 2014;37: 2034-2054.

46. Brazil. Clinical guideline for rheumatoid arthritis. Available:

http://conitec.gov.br/images/Protocolos/pcdt ArtriteReumatoide 2015.pdf.

47. Brazil. Clinical guideline for multiple sclerosis. Available:

http://conitec.gov.br/images/Protocolos/PCDT Retificacao EscleroseMultipla 06.07. 2015.pdf.

48. Brazil. Clinical guideline for breast cancer. Available: http://conitec.gov.br/images/Protocolos/DDT/DDT CaMama 2015.pdf.

49. Brazilian society of diabetes. Clinical guidelines concerning the use of insulin analogues. Available: http://www.diabetes.org.br/images/pdf/posicionamento-sbd.pdf. 50. Bachle C, Icks A, Strassburger K, Flechtner-Mors M, Hungele A, Beyer P, et al. Initiative and the German BMBF competence network diabetes mellitus. Direct diabetes-related costs in young patients with early-onset, long-lasting type 1 diabetes. PLoS One. 2013;8: e70567.

51. Frier BM, Russell-Jones D, Heise T. A comparison of insulin detemir and neutral protamine Hagedorn (isophane) insulin in the treatment of diabetes: a systematic review. Diabetes, Obesity and Metabolism. 2013 Nov 1;15(11):978-86.

52. Haukka J, Hoti F, Erästö P, Saukkonen T, Mäkimattila S, Korhonen P. Evaluation of the incidence and risk of hypoglycemic coma associated with selection of basal 
insulin in the treatment of diabetes: a Finnish register linkage study.

Pharmacoepidemiology and drug safety. 2013 Dec 1;22(12):1326-35.

53. Shah A, Chen H, Rajan SS, Johnson M. PDB106 Impact of long acting insulin agents on health related quality of life (HRQoL), Health Care Expenditures and Utilization. Value in Health. 2012;15: A190.

54. Cammarota S, Bruzzese D, Catapano AL, Citarella A, De Luca L, Manzoli L, Masulli M, Menditto E, Mezzetti A, Riegler S, Putignano D. Lower incidence of macrovascular complications in patients on insulin glargine versus those on basal human insulins: A population-based cohort study in Italy. Nutrition, Metabolism and Cardiovascular Diseases. 2014 Jan 31;24(1):10-7.

55. Kostev K, Dippel FW, Bierwirth R. Resource consumption and costs of treatment in patients with type 1 diabetes under intensified conventional therapy under german real-life conditions. Journal of diabetes science and technology. 2013 May 1;7(3):736-42. 


\section{CUSTO-EFETIVIDADE DAS TERAPIAS DISPONÍVEIS PARA DIABETES TIPO 1 NO BRASIL: PERSPECTIVA DO SISTEMA ÚNICO DE SAÚDE}

\subsection{RESUMO}

Objetivo: Calcular a razão incremental de custo-utilidade das alternativas terapêuticas para tratamento do diabetes tipo 1 no Brasil, considerando múltiplas injeções diárias (MDI) com associação entre insulinas humanas e análogas, MDI com insulinas análogas (análogas de longa duração + análogas de ação rápida) e bomba de insulina.

Perspectiva: Sistema Único de Saúde do Brasil

Métodos: Foi realizada uma análise de custo-utilidade, cujo desfecho final foi custo/ano de vida ajustado por qualidade (QALY). Foi utilizado um modelo de Markov para representar possíveis estados de saúde, pelos quais os pacientes com DM1 transitam ao longo do tempo. O horizonte temporal foi referente à expectativa de vida (lifetime), e consideramos ciclos de 1 ano de duração. Incluíram-se todos os custos diretos médicos cobertos pelo sistema público de saúde, os quais compreendem as intervenções e custos hospitalares médios das complicações crônicas microvasculares. Considerou-se que cada complicação e cada estado associado estão relacionados a diferentes utilidades, coletadas de modelos prévios. A efetividade das intervenções foi considerada em termos de redução da hemoglobina glicada e consequente redução das complicações.

Resultados: Entre as alternativas terapêuticas comparadas, a única que se mostrou custo-efetiva, isto é, abaixo do limiar de disposição a pagar, foi a associação de insulina NPH e insulinas análogas de ação rápida. As razões incrementais de custoefetividade foram $R \$ 8,6$ mil para associação entre insulina NPH e insulinas análogas de ação rápida, $R \$ 106$ mil para associação entre insulinas análogas de longa duração e ação rápida e $R$ \$ 186,5 mil para a bomba de insulina.

Discussão: A estratégia mais custo-efetiva foi a associação entre insulinas NPH e análogas de ação rápida, a qual já está incorporada ao SUS a nível nacional. Outra alternativa que se mostrou interessante, com potencial de discussão para cobertura, foi a associação entre insulinas análogas de longa duração e de ação rápida, a qual 
apresentou razão de custo-efetividade incremental ligeiramente superior ao limite proposto para países em desenvolvimento. Como limitação, ao definir o custo da bomba e seus insumos no estudo, não foram modelados potenciais ganhos de barganha caso a bomba fosse incorporada no SUS, visto que o Ministério da Saúde seria o maior comprador deste dispositivo em âmbito nacional. Nas demais estratégias, esses ganhos foram considerados. Assim, essa premissa adotada no estudo pode ter desfavorecido a bomba. 


\subsection{INTRODUÇÃO}

A prevalência mundial do diabetes está estimada em $9 \%$ e esse número cresce mais rapidamente nos países em desenvolvimento (1). Do total de pessoas com diabetes, 5 a $10 \%$ tem o tipo 1 da doença $(1,2,3)$. Nesse contexto, o diabetes mellitus tipo 1 (DM1) é uma condição de saúde de alto impacto para os sistemas de saúde. Isso não se deve somente ao fato de ser uma doença crônica, com início geralmente na infância, que afeta pessoas economicamente ativas, de alto impacto pessoal e social. Deve-se também aos gastos crescentes, envolvendo a terapia e as novas tecnologias a ela relacionadas e, principalmente, as diversas complicações crônicas associadas $(4,5)$.

Segundo a Organização Mundial de Saúde (6), após 15 anos de doença, 2\% dos diabéticos estarão cegos, 30 a $45 \%$ terão retinopatia em algum grau, 10\% retinopatia grave, 10 a $20 \%$ terão nefropatia, 20 a $35 \%$ neuropatia, e 10 a $25 \%$ deles terão desenvolvido algum tipo de doença cardiovascular. Sabe-se também que a expectativa de vida de um indivíduo portador de DM1 é reduzida em média em 15 anos (7).

Para esses pacientes, já é notoriamente estabelecido que o tratamento intensivo, baseado em três ou mais injeções diárias, numa associação de perfis de insulina basal (ação intermediária ou longa) e bólus (ação rápida), está relacionado à diminuição do risco de complicações (8).

Diante de todas as opções terapêuticas para DM1, ainda restam dúvidas sobre qual das alternativas é a mais custo-efetiva na realidade brasileira. Embora existam vários estudos econômicos publicados no tema, estes usualmente comparam insulinas humanas e análogas $(9,10)$, análogas entre si $(11,12)$ ou o sistema de infusão contínua e as múltiplas injeções diárias (13). Não existem estudos de custo-efetividade que incluam todas as alternativas e combinações entre os tipos de insulina e as formas de administração.

O objetivo deste estudo foi calcular a razão incremental de custo-utilidade das alternativas terapêuticas para tratamento do diabetes tipo 1 no Brasil, considerando múltiplas injeções diárias (MDI) com associação entre insulinas humanas e análogas, MDI com insulinas análogas (análogas de longa duração + análogas de ação rápida) e bomba de insulina (com análogas de ação rápida). Tais opções foram 
comparadas ao caso-base, representado por múltiplas injeções diárias com insulinas humanas (NPH + Regular), terapia tradicional disponível atualmente no Sistema Único de Saúde (SUS). Além disso, espera-se entender os fatores que contribuem para o incremento de custo, mediante análise de sensibilidade.

\subsection{MÉTODOS}

\subsubsection{Contexto}

Foi realizada uma análise de custo-utilidade, comparando-se as seguintes alternativas terapêuticas: (1) associação de insulinas humanas NPH e Regular (caso-base); (2) associação de insulina humana NPH e insulinas análogas de ação rápida (também disponíveis no SUS); (3) associação de insulinas análogas de longa duração e ação rápida; e (5) bomba de insulina com insulinas análogas de ação rápida. Optou-se por não avaliar subgrupos populacionais. O desfecho final dessa análise é custo/ano de vida ajustado por qualidade (QALY).

A análise de custo-utilidade foi baseada nos critérios de qualidade propostos pelo Consolidated Health Economic Evaluation Reporting Standards - CHEERS Checklist (26). Toda a análise foi realizada no software TreeAge Pro $2015 \AA$.

\subsubsection{Modelo}

Foi utilizado um modelo de Markov para representar possíveis estados de saúde, pelos quais os pacientes com DM1 transitam ao longo do tempo. Foram considerados dez estados de saúde, os quais estão relacionados a três complicações do DM1 (nefropatia, neuropatia e retinopatia). A Figura 4.1 mostra o esquema do modelo e a relação entre os estados de Markov. 


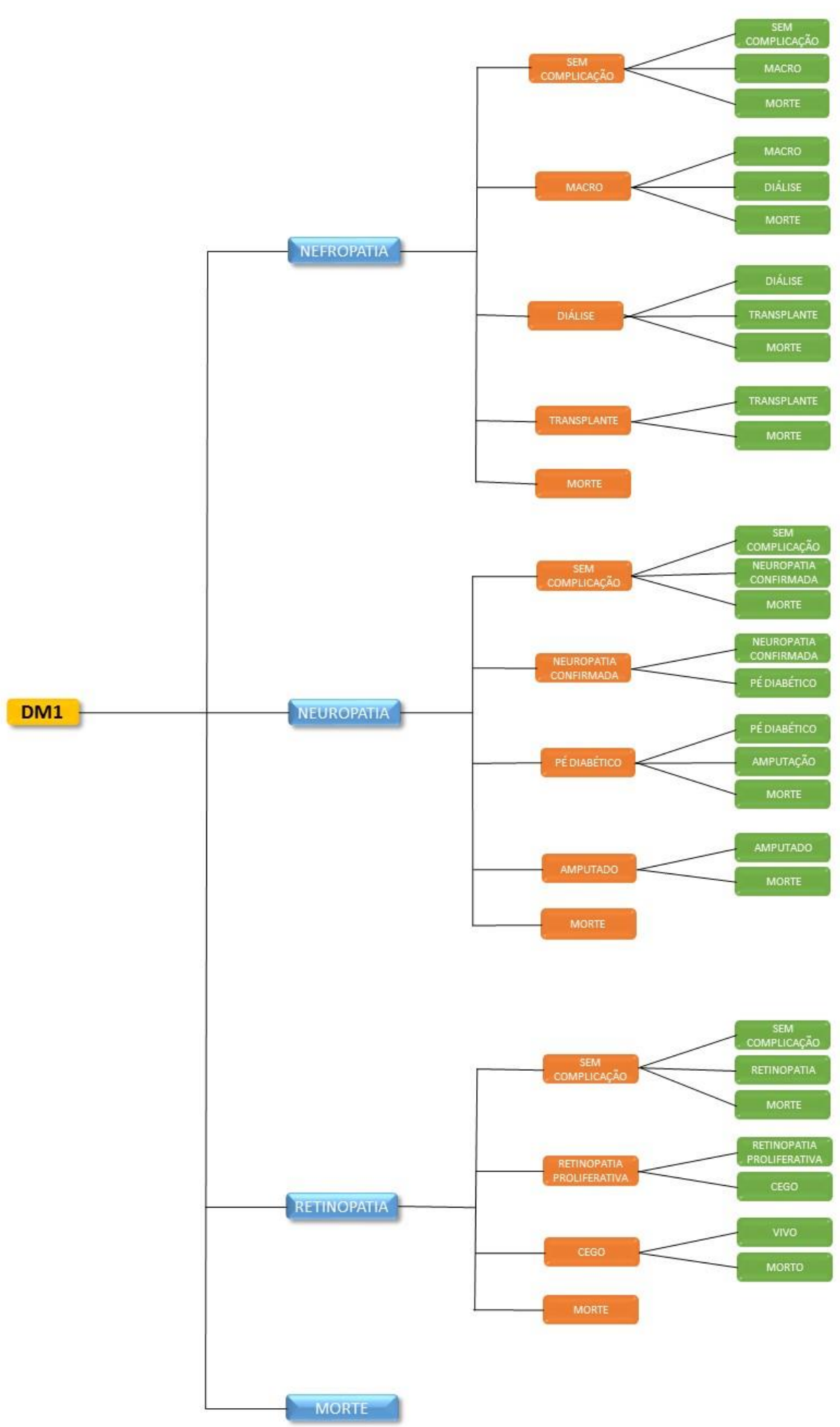

Figura 4.1 Representação do modelo de custo-utilidade utilizado. 
Devido à limitação do software utilizado na análise, o qual não permite a existência de dois ciclos de Markov seguidos na árvore de decisão, consideramos o estado "Sem complicação" dentro de cada uma das complicações. Dessa forma, garantimos que todos os indivíduos do modelo, após entrada neste, poderiam passar pelas probabilidades de desenvolvimento de complicações. Importante frisar que não se considerou a possibilidade de coexistência de complicações.

Considerou-se que um indivíduo com diabetes tipo 1 entra no modelo ao diagnóstico. Os indivíduos permanecem no modelo desde o diagnóstico até a morte, já que o horizonte temporal é referente à expectativa de vida (lifetime), por se tratar de uma doença crônica. Consideramos ciclos de 1 ano de duração, os quais ponderamos como os mais apropriados com relação aos dados dos estudos primários incluídos.

Todos os indivíduos estão sujeitos à mesma probabilidade de desenvolver complicações crônicas microvasculares, independente da idade e tempo de diagnóstico. As probabilidades de desenvolvimento de cada uma das complicações são diferentes e foram coletadas de modelos para diabetes tipo 1 já existentes e utilizados largamente em diversos países: CORE Diabetes Model $(14,15)$ e SHEFFIELD Type 1 Diabetes Policy Model (16). Para as probabilidades não incluídas nos modelos internacionais, utilizaram-se dados da literatura médica, preferencialmente do Brasil. Todas as probabilidades de transição entre os estados e as respectivas origens dos dados são exibidas na Tabela 4.1. 
Tabela 4.1 - Probabilidades de transição entre os estados do Modelo de Markov

\begin{tabular}{lrll}
\hline \multicolumn{1}{c}{ Estados } & Probabilidades & \multicolumn{1}{c}{ Referências } \\
\hline Diabético para nefropatia & 0.2381 & OMS $^{*}(17)$ \\
\hline Sem complicação para macroalbuminúria & 0.4201 & OMS $^{* *}(17)$ \\
\hline Nefropatia para macroalbuminúria & 0.094 & Gomes et al., 2014 (18) \\
\hline Diabético para morte & 0.00361 & $\begin{array}{l}\text { Harjutsalo et al., 2011 } \\
(19)\end{array}$ \\
\hline Nefropatia para macroalbuminúria & 0.094 & Gomes et al., 2014 (18) \\
\hline Macroalbuminúria para diálise & 0.1579 & DCCT (20) \\
\hline Macroalbuminúria para morte & 0.007 & DCCT (20) \\
\hline Nefropatia para diálise & 0.0840 & Estimativa DCCT (20) \\
\hline Diálise para transplante & 0.0857 & Silva et al., 2008 (21) \\
\hline Diálise para morte & 0.17 & Silva et al., 2008 (21) \\
\hline Nefropatia para transplante (inicial) & 0.0001 & Premissa \\
\hline Transplante para morte & 0.047 & Silva et al., 2008 (21) \\
\hline Diabético para neuropatia & 0.4725 & OMS* (17) \\
\hline Sem complicação para neuropatia & 0.4232 & OMS** (17) \\
confirmada & 0.15 & Dalla \& Faglia, 2006 (22) \\
\hline Neuropatia confirmada para pé diabético & 0.85 & $\begin{array}{l}\text { Apelqvist \& Larsson, 2000 } \\
(23)\end{array}$ \\
\hline Pé diabético para amputação & 0.0354 & DCCT (20) \\
\hline Neuropatia para pé diabético (inicial) & 0.0001 & Premissa \\
\hline Neuropatia para amputação (inicial) & 0.128 & Rezende et al., 2008 (24) \\
\hline Amputação para morte & 0.2857 & OMS* (17) \\
\hline Diabético para retinopatia & 0.3500 & OMS** (17) \\
\hline Sem complicação para retinopatia \\
proliferativa
\end{tabular}

${ }^{*}$ A OMS considera como limite inferior de risco para todos os diabéticos: $10 \%$ de nefropatia, $20 \%$ de neuropatia, $10 \%$ de retinopatia grave e $2 \%$ de cegueira. Aplicamos essa distribuição de percentuais (42\%) a $100 \%$ da população inicial. Logo, o risco basal de neuro, nefro e retinopatia foram ajustados como $23,80 \%, 47,25 \%$ e $28,57 \%$, respectivamente (considerando que dentro desse percentual temos pessoas sem complicação, porém em risco). ${ }^{* *}$ Aplicamos a mesma magnitude de risco inicial proporcional à população específica em cada braço de complicações, logo os riscos de desenvolvimento de nefro (macroalbuminúria), neuro e retinopatia proliferativa foram: $42,01 \%$, $42,32 \%$ e $35 \%$, respectivamente.

Foi considerada uma taxa de desconto de $5 \%$ nos custos e benefícios em saúde, variando de 0 a $10 \%$ na análise de sensibilidade (25). 


\subsubsection{Custos}

Adotou-se a perspectiva do SUS como pagador, portanto incluíram-se todos os custos diretos médicos cobertos pelo sistema público de saúde. Os custos considerados compreendem as intervenções e custos hospitalares médios das complicações crônicas microvasculares.

Não foram levados em consideração os custos relacionados a consultas médicas periódicas, exames, rastreamento de complicações, acompanhamento ambulatorial, assim como os custos da auto-monitorização glicêmica, aquisição de glicosímetros e tiras para testes de glicemia. Para isso, nos baseamos no fato de que a utilização de tais recursos não seria diferente entre os braços de comparação. Uma limitação de dado diz respeito ao financiamento da auto-monitorização, o qual é co-participado por União, Estados e municípios, numa taxa fixa per-capita (27), que inclui outros gastos com diabetes.

A identificação de recursos foi realizada utilizando-se a técnica mista, com macrocusteio (base administrativa de dados secundários do DATASUS) e microcusteio (estudos publicados de acompanhamento de pacientes com DM1), de acordo com a disponibilidade dos dados. Os custos utilizados e fontes de informação são descritos na Tabela 4.2. 
Tabela 4.2 - Custos utilizados no modelo e fontes de informação

\begin{tabular}{lrll}
\hline \multicolumn{1}{c|}{ Itens de custo } & \multicolumn{1}{c}{ Valor } & \multicolumn{1}{c}{ Fonte } \\
\hline Custo da insulina NPH / $\mathrm{mL}$ & 0,903 & DOU \\
\hline Custo das insulinas análogas de longa duração / mL & 13,60 & DODF \\
\hline Custo das insulinas análogas de ação rápida / $\mathrm{mL}$ & 1,32 & DODF \\
\hline Custo da bomba de insulina & 5000,00 & DODF \\
\hline Custo dos cateteres para bomba de insulina & 408,88 & DODF \\
\hline Custo do reservatório para bomba de insulina & 124.00 & DODF \\
\hline Custo de seringas & 0.046 & DOSP \\
\hline Custo da macroalbuminúria & 5980,27 & SIH-SUS \\
\hline Custo da diálise & 34849,36 & Silva et al., 2016 (21) \\
\hline Custo do transplante renal $-1^{\circ}$ ano & 78401.26 & Silva et al., 2016 (21) \\
\hline Custo do transplante renal - 2º ano & 7970.85 & Silva et al., 2016 (21) \\
\hline Custo da neuropatia & 772,10 & SIH-SUS \\
\hline Custo do pé diabético & 426.10 & Rezende et al., 2008 (24) \\
\hline Custo da amputação - $1^{\circ}$ ano & 3037,30 & Rezende et al., 2008 (24) \\
\hline Custo da amputação - $2^{\circ}$ ano & 426,10 & Rezende et al., 2008 (24) \\
\hline Custo médio da prótese & 2193,00 & SIGTAP \\
\hline Custo da retinopatia & 446.41 & SIH-SUS \\
\hline
\end{tabular}

SIGTAP: Sistema de Gerenciamento da Tabela de Procedimentos, Medicamentos, Órteses, Próteses e Materiais Especiais do SUS. DODF: Diário Oficial do Distrito Federal. SIH-SUS: Sistema de Informações Hospitalares do SUS. DOU: Diário Oficial da União. DOSP: Diário Oficial de São Paulo.

No caso das insulinas, para as disponibilizadas pelo SUS nacional foi considerado o preço praticado em compras do Ministério da Saúde, por meio do Diário Oficial da União. Para as insulinas análogas, foi considerado o preço praticado por Estados que já as disponibilizam em protocolos assistenciais, localizado por meio dos Diários Oficiais estaduais. O limite inferior, no caso das insulinas humanas, foi uma suposição de redução de $20 \%$, e no caso das insulinas análogas foi o valor com aplicação do poder de barganha, cujo racional do cálculo foi publicado em artigo prévio (28). O limite superior foi a média ponderada por $\mathrm{mL}$ do Preço Máximo de Venda ao Governo (28). A média de doses considerada foi proveniente de um estudo de coorte multicêntrico brasileiro, que ponderou variáveis em relação às intervenções dos participantes (18) (Tabela 4.3). Utilizou-se peso médio de $65 \mathrm{~kg}$, variando de 50 a $70 \mathrm{~kg}$. 
Tabela 4.3 - Dose média (desvio padrão) das intervenções avaliadas (18)

\begin{tabular}{l|c}
\hline \multicolumn{1}{c}{ Intervenção } & Dose (U/Kg/dia) \\
\hline $\mathbf{N P H}+$ Regular & $0,9 \pm 0,4^{*}$ \\
\hline NPH & $0,5 \pm 0,3$ \\
\cline { 2 - 2 } Análoga rápida & $0,4 \pm 0,3$ \\
\hline Análoga lenta & $0,4 \pm 0,3$ \\
Análoga rápida & $0,4 \pm 0,3$ \\
\hline Bomba & $0,7 \pm 0,3$
\end{tabular}

Legenda: A média das doses fornecida pelo estudo multicêntrico brasileiro não é dissociada, por isso: *considerou-se 0,9 U/Kg/dia da associação, pois o preço de ambas as insulinas é o mesmo.

Os custos relacionados à bomba de insulina e seus itens descartáveis (cateteres, reservatório) foram localizados no Diário Oficial do Distrito Federal, o qual possui protocolo de dispensação de bomba. Localizamos também o valor de mercado dos itens, por meio de busca no sítio eletrônico dos fabricantes e em compras estaduais referentes à judicialização. O menor e maior preço foram utilizados, respectivamente, como limites inferior e superior para a análise de sensibilidade.

Como a bomba de insulina é um insumo suscetível a trocas ao longo do horizonte temporal, simulamos a sua durabilidade média em 6 anos, variando de 2 a 10. Nesse caso, é importante destacar que neste estudo não consideramos diferenças entre marcas, visto que se subentende que as marcas irão competir na concorrência de preços das licitações públicas. Porém, uma das empresas produtoras de bombas (Medtronic) oferece garantia perpétua, enquanto para a outra marca disponível (Roche) a bomba tem vida útil programada, que varia de 2 a 6 anos.

No que concerne aos custos das complicações, foi inicialmente realizada uma busca na literatura. Com relação aos custos relacionados à amputação no $1^{\circ}$ ano, estes foram obtidos do estudo de Rezende e colaboradores (24) e são referentes à internação e procedimentos hospitalares e cirúrgicos médios por episódio. Para tornar o modelo mais realista, acrescentamos custos relativos à prótese, com base em busca no Sistema de Gerenciamento da Tabela de Procedimentos, Medicamentos e OPM do SUS - SIGTAP, optando-se por incluir uma prótese intermediária de membros inferiores de valor médio. Os custos do pé diabético e da amputação a partir do $2^{\circ}$ ano foram os mesmos, e também foram obtidos do estudo 
de Rezende e col. (24), utilizando-se as estimativas de custos médios de internações para procedimentos cirúrgicos sem amputação.

Os custos relativos à diálise e aos transplantes foram obtidos do estudo de Silva e colaboradores (21). Os custos relacionados a neuropatia, macroalbuminúria e retinopatia proliferativa foram retirados do DATASUS, a partir de busca no Sistema de Informações Hospitalares, cruzando com os códigos CID E10.2, E10.3 e E10.4, respectivamente, diabetes mellitus insulino-dependente com complicações renais, oftálmicas e neurológicas. Utilizamos o custo médio por internação para os códigos mencionados, o qual consideramos apenas para o primeiro estágio das complicações. A utilização de recursos nesse caso foi baseada em premissas.

\subsubsection{Efetividade}

A efetividade das intervenções foi considerada em termos de redução da hemoglobina glicada (A1C) (Tabela 4.4 e 4.5). Os dados de efetividade foram obtidos, segundo o que se segue:

(1) NPH + Regular: consideramos que o caso-base não interfere nos desfechos em saúde, uma vez que todas as alternativas foram comparadas a ele e os benefícios medidos são relativos.

(2) $\mathrm{NPH}+$ Análogas de rápida duração: dados de revisão sistemática sobre a eficácia das insulinas análogas de rápida duração comparadas à insulina humana Regular (29).

(3) Análogas de longa duração + análogas de ação rápida: dados advindos de overview de revisões sistemáticas elaborada pelo próprio grupo de estudo desta análise (análise de subgrupo).

(4) Bomba de insulina: dados advindos de revisões sistemáticas sobre a eficácia de bombas de insulina comparadas a MDI (30). 
Tabela 4.4 - Medidas de efetividade das intervenções comparadas

\begin{tabular}{l|l|l}
\hline \multicolumn{1}{c|}{ Intervenções } & Diminuição da A1C (IC95\%) & \multicolumn{1}{c}{ Referências } \\
\hline $\begin{array}{l}\text { NPH + Análogas de rápida } \\
\text { duração }\end{array}$ & $-0,15 \%(-0,2 ;-0,1)$ & Fullerton et al., 2016 (29) \\
$\begin{array}{l}\text { Análogas de longa + } \\
\text { rápida duração }\end{array}$ & $-0,19 \%(-0,33 ;-0,05)$ & Overview 2017 \\
Bomba de insulina & $-1,2 \%(-0,95 ;-1,2)$ & Weissberg-Benchel et al., \\
& & $2003(30)$ \\
\hline
\end{tabular}

Tabela 4.5 - Aplicação da redução percentual de A1C no risco de desenvolvimento de complicações (20)

\begin{tabular}{l|rrrr}
\hline \multirow{2}{*}{ Intervenções } & \multicolumn{3}{|c}{$\begin{array}{r}\text { Probabilidades de desenvolvimento de } \\
\text { cada complicação }\end{array}$} \\
\hline Análogas de ação rápida & Caso-base & Lim inferior & Lim superior \\
\hline Macroalbuminúria & 0,4007 & 0,3206 & 0,4809 \\
\hline Diálise & 0,0817 & 0,0654 & 0,0981 \\
\hline Neuropatia & 0,4062 & 0,3250 & 0,4875 \\
\hline Pé diabético & 0,0339 & 0,0271 & 0,0407 \\
\hline Retinopatia & 0,3311 & 0,2649 & 0,3974 \\
\hline Análogas de longa duração & Caso-base & Lim inferior & Lim superior \\
\hline Macroalbuminúria & 0,3956 & 0,3164 & 0,4747 \\
\hline Diálise & 0,0812 & 0,0649 & 0,0974 \\
\hline Neuropatia & 0,4018 & 0,3214 & 0,4821 \\
\hline Pé diabético & 0,0336 & 0,0268 & 0,0403 \\
\hline Retinopatia & 0,3262 & 0,2609 & 0,3914 \\
\hline Bomba de insulina & Caso-base & Lim inferior & Lim superior \\
\hline Macroalbuminúria & 0,2647 & 0,2117 & 0,3176 \\
\hline Diálise & 0,0663 & 0,0530 & 0,0796 \\
\hline Neuropatia & 0,2877 & 0,2302 & 0,3453 \\
\hline Pé diabético & 0,0240 & 0,0192 & 0,0288 \\
\hline Retinopatia & 0,1995 & 0,1596 & 0,2394 \\
\hline
\end{tabular}

\subsubsection{Utilidades}

Nesse modelo, o desfecho em saúde final da análise é o custo por anos de vida ajustados por qualidade. Considerou-se que cada complicação e, logo, cada estado associado, está relacionada a uma utilidade. Portanto, cada estado de Markov está associado a diferentes utilidades, coletadas de modelos prévios e 
retiradas da literatura internacional, as quais estão descritas na Tabela 4.6 $(14,15,16)$.

Tabela 4.6 - Utilidades das complicações crônicas microvasculares do diabetes tipo 1 , segundo dois modelos pré-estabelecidos

\begin{tabular}{lr}
\hline Estados & \multicolumn{1}{c}{ Utilidade } \\
\hline Diabetes sem complicação & $0.814(15)$ \\
\hline Macroalbuminúria & $0.797(16)$ \\
\hline Diálise & $0.49(15)$ \\
\hline Transplante & $0.762(15)$ \\
\hline Neuropatia & $0.624(15)$ \\
\hline Pé Diabético & $0.6(15)$ \\
\hline Amputação 1 ano & $0.698(16)$ \\
\hline Amputação 2 ano & $0.68(15)$ \\
\hline Retinopatia & $0.794(15)$ \\
\hline Cegueira & $0.606(16)$ \\
\hline
\end{tabular}

\subsubsection{Limiar de disposição a pagar}

No Brasil atualmente não existe um limiar de custo-efetividade pré-definido para análises de economia da saúde. No entanto, de acordo com as recomendações da Diretriz Nacional de Análises Econômicas em Saúde do Ministério da Saúde do Brasil (25) e da Comissão Nacional de Incorporação de Tecnologias no SUS (32), utilizam-se limiares entre uma e três vezes o Produto Interno Bruto (PIB) per capita. Nesse sentido, considerando os dados de 2015 (33), o limiar ficaria entre $R \$$

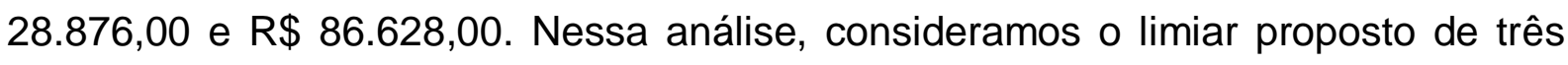
vezes o PIB per capita. 


\subsubsection{Análise de sensibilidade}

Foi realizada análise de sensibilidade univariada por meio do Diagrama de Tornado, objetivando identificar as variáveis que mais afetam a incerteza do modelo e o quanto dessa incerteza pode ser explicada pelas variáveis identificadas.

Quando não havia informação sobre variabilidade, em termos de desvio padrão ou intervalo de confiança das probabilidades utilizadas, adotamos a premissa de variação de mais ou menos $20 \%$ do valor total do parâmetro, representando os limites superior e inferior, respectivamente. Para utilidades, a variação foi $10 \%$.

\subsection{RESULTADOS}

Os resultados sugerem que, entre as alternativas terapêuticas comparadas, a única que se mostrou custo-efetiva, isto é, abaixo do limiar de disposição a pagar considerado, foi a associação de insulina NPH e insulinas análogas de ação rápida. O resultado é mostrado na Figura 4.2. Importante perceber nesta figura uma linha preta contínua com a sigla WTP, ou seja, willingness to pay, a qual ilustra o limiar de custo-efetividade de três vezes o PIB per capita.

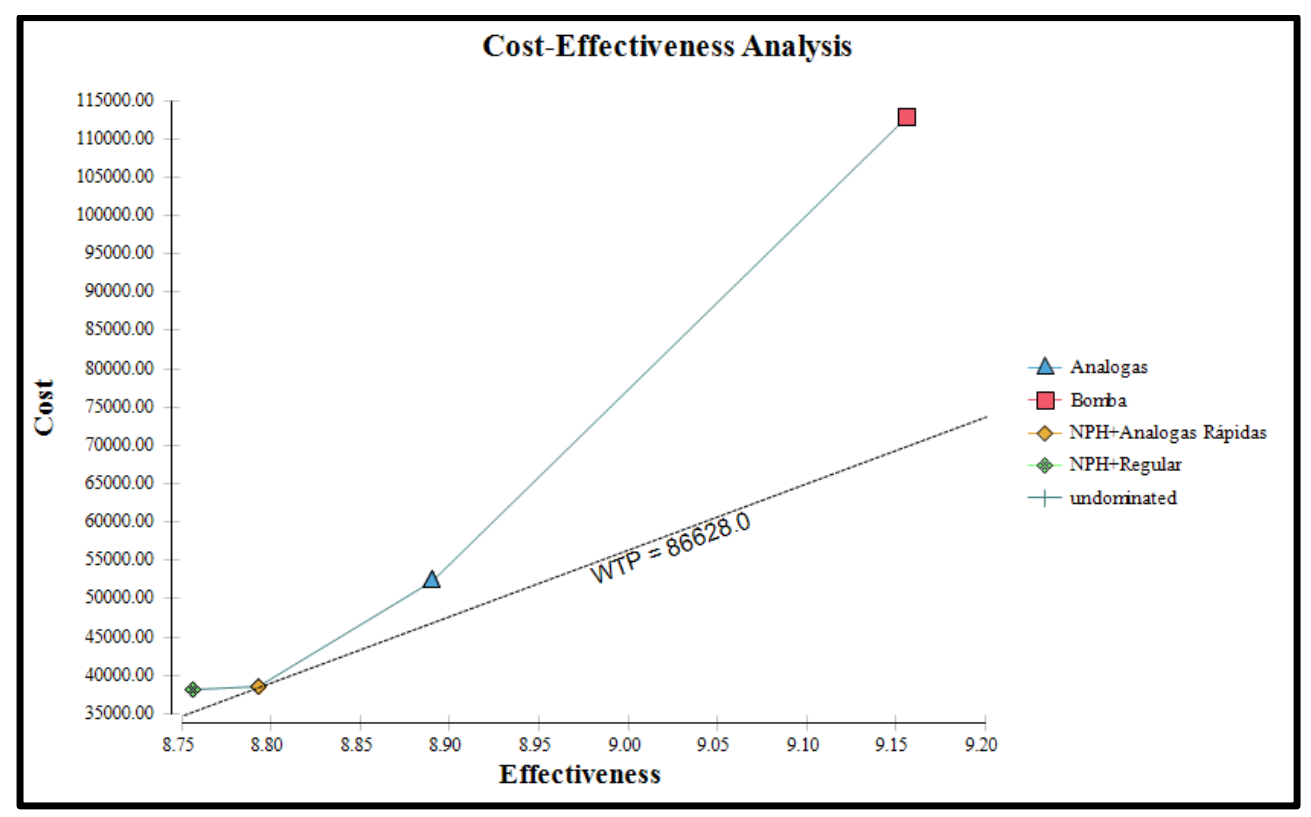

Figura 4.2 Gráfico da análise de custo-efetividade 
A Figura 4.2 mostra ainda que a associação entre insulinas análogas de longa duração e ação rápida ficou posicionada bem próxima ao limiar, com razão incremental de custo-efetividade de $\mathrm{R} \$ 106$ mil. Da mesma forma, a bomba de insulina se destaca por agregar custos, mas também trazendo importante aumento na utilidade frente às outras alternativas.

Na Tabela 4.7 são apresentados os resultados em termos de custos e QALY incrementais, além das razões incrementais de custo-efetividade em comparação ao caso-base.

Tabela 4.7 - Razão incremental de custo-efetividade das alternativas terapêuticas estudadas

\begin{tabular}{lrrr}
\hline \multicolumn{1}{c}{ Intervenções } & $\begin{array}{c}\text { Custo } \\
\text { incremental (R\$) }\end{array}$ & $\begin{array}{c}\text { QALY } \\
\text { incremental }\end{array}$ & $\begin{array}{r}\text { Razão incremental de } \\
\text { custo-efetividade (R\$) }\end{array}$ \\
\hline $\begin{array}{l}\text { NPH + Análogas de } \\
\text { ação rápida }\end{array}$ & 319,66 & 0,04 & $8.639,59$ \\
\hline $\begin{array}{l}\text { Análogas de longa } \\
\text { duração + ação rápida }\end{array}$ & $14.206,63$ & 0,13 & $106.087,22$ \\
\hline Bomba de insulina & $74.693,98$ & 0,40 & $186.551,40$ \\
\hline
\end{tabular}

O diagrama de tornado (Figura 4.3) mostrou que as variáveis que mais influenciaram na incerteza do modelo foram as utilidades dos estados de complicação. A utilidade da retinopatia, por exemplo, é responsável por explicar cerca de $27 \%$ da incerteza. Somando-se a interferência das utilidades de retinopatia, cegueira, neuropatia, amputação no $2^{\circ}$ ano, diabetes sem complicações e macroalbuminúria, elas explicam juntas cerca de $92 \%$ das incertezas do modelo utilizado. 


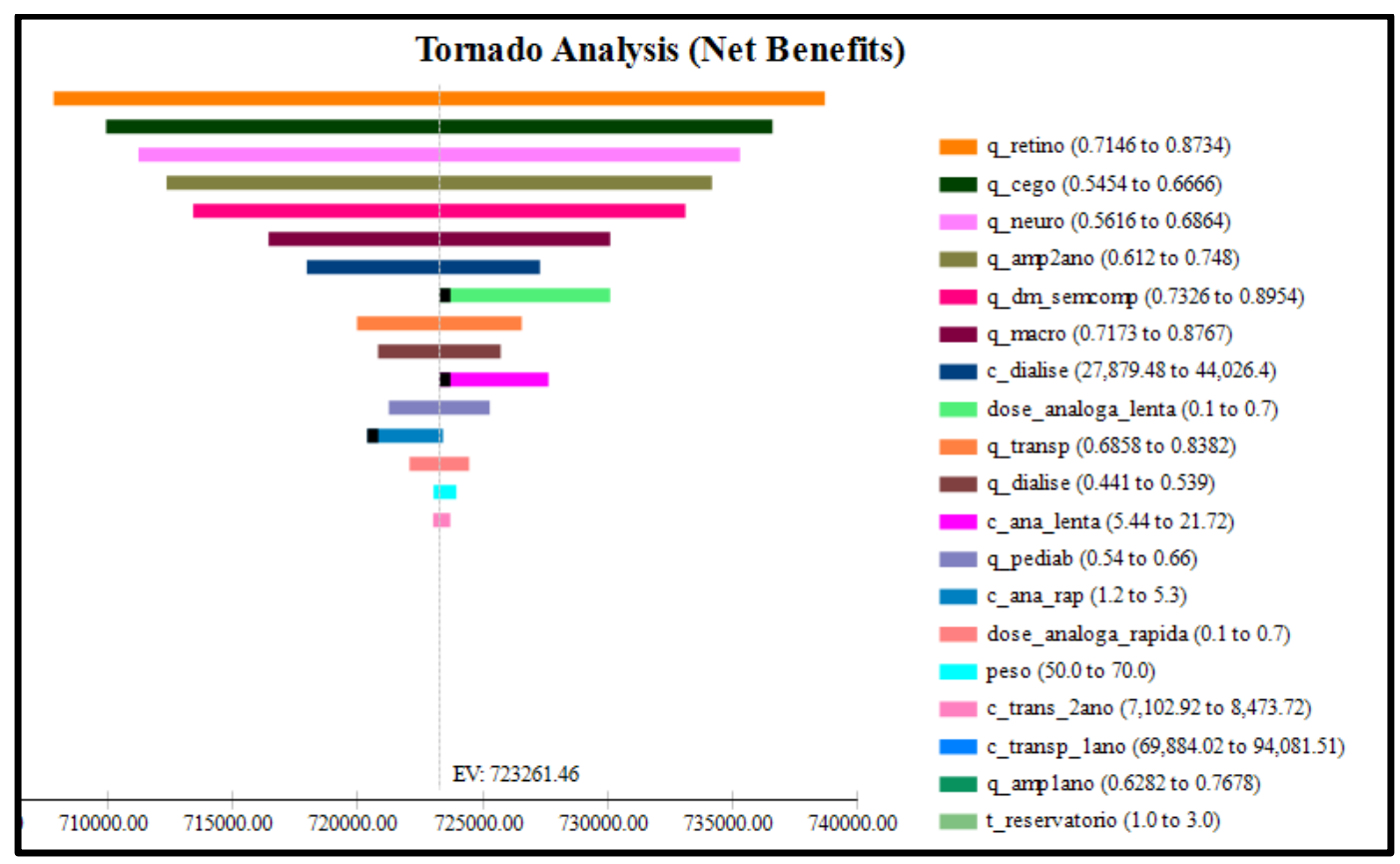

Figura 4.3 Diagrama de Tornado, mostrando as variáveis do modelo e a influência de cada uma na incerteza do resultado

\subsection{DISCUSSÃO}

Os resultados dessa análise de custo-utilidade apontam resultados semelhantes a outros estudos publicados internacionalmente, os quais avaliaram as mesmas intervenções analisadas no nosso estudo de forma independente $(9,12,13)$. Como dito anteriormente, embora haja diversos modelos internacionais sobre o tema, não é de nosso conhecimento que exista algum modelo que incluiu todas as alternativas terapêuticas aqui consideradas.

Nota-se em nossos resultados que, ao longo do horizonte temporal estudado, a bomba de insulina proporcionaria maior benefício em termos de anos de vida ajustados por qualidade em comparação às demais alternativas. No entanto, o benefício incremental em QALY da bomba não foi suficiente para compensar seu custo incremental, que foi o maior entre as tecnologias consideradas. Importante salientar, nesse caso, que o incremento do custo não se dá apenas devido aos valores do preço da tecnologia e seus insumos descartáveis, mas também, e principalmente, ao incremento nos anos de vida ganhos e de seus custos associados. 
Cabe ressaltar que, ao definir o custo da bomba no estudo, não foram modelados potenciais ganhos de barganha caso a bomba fosse incorporada no SUS, visto que o Ministério da Saúde seria o maior comprador deste dispositivo em âmbito nacional. Nas demais estratégias ( $\mathrm{NPH}$, análogas rápidas e lentas), os ganhos de barganha foram considerados. Assim, essa premissa adotada no estudo pode ter desfavorecido a bomba. Em estudo recente, evidenciou-se que o poder de barganha tem gerado redução substancial de preços das compras centralizadas no Brasil (28).

Nesse contexto, as insulinas análogas de longa duração, ainda não cobertas pelo SUS a nível nacional, deveriam ser consideradas para discussão sobre cobertura, já que, no nosso modelo, apresentaram uma relação de custo-efetividade bem próxima ao limiar proposto, trazendo acréscimo importante no que diz respeito a utilidades e redução de complicações.

Finalmente, algumas limitações deste estudo podem ser apontadas, como por exemplo, não termos considerado que as probabilidades de desenvolvimento de complicações variam com a idade e tempo de diagnóstico. No nosso modelo, um paciente recém-diagnosticado apresenta o mesmo risco de complicações que outro no final da vida e isso não traduz a realidade da história clínica da doença. Outro fator limitante da análise foi a falta de dados nacionais, tanto epidemiológicos e de custo quanto de utilidade (anos de vida ajustados por qualidade). Isso proporcionou que nosso modelo fosse baseado em muitas premissas, o que pode ter aumentado a incerteza dos resultados. Outras limitações foram a não inclusão dos custos ambulatoriais (consultas, exames, auto-monitorização) e a falta de análise de sensibilidade probabilística.

Como recomendações para a pesquisa, temos a necessidade urgente de dados de utilização de custos e recursos de vida real pelos pacientes DM1 na realidade brasileira, no que concerne não só ao tratamento do diabetes, mas também das complicações associadas.

Em termos de recomendações para a política de saúde, considera-se importante discutir as opções terapêuticas para diabetes tipo 1 de forma abrangente, ponderando benefícios e custos e considerando o poder de barganha como ferramenta na obtenção de preços sustentáveis para o sistema de saúde. 


\section{REFERÊNCIAS}

1. International Diabetes Federation. IDF Diabetes Atlas. ISBN: 2-930229-85-3.

Disponível em: http://www.diabetesatlas.org/. Acessado em: 06/05/2016.

2. Zimmet $P$, Alberti KG, Shaw J. Global and societal implications of the diabetes epidemic. Nature. 2001 Dec 13;414(6865):782-7.

3. Patterson C, Guariguata L, Dahlquist G, Soltész G, Ogle G, Silink M. Diabetes in the young - a global view and worldwide estimates of numbers of children with type 1 diabetes. Diabetes Res Clin Pract. 2014 Feb;103(2):161-75.

4. Schmidt MI, Duncan BB, Silva GA, Menezes AM, Monteiro CA, Barreto SM et al. Chronic non-communicable diseases in Brazil: burden and current challenges. Lancet 2011; 377:1949-61.

5. Sociedade Brasileira de Diabetes. Diretrizes da Sociedade Brasileira de Diabetes (2015-2016) / Adolfo Milech [et. al.]; organização José Egidio Paulo de Oliveira, Sérgio Vencio - São Paulo: A.C. Farmacêutica, 2016. Disponível em: http://www.diabetes.org.br/sbdonline/images/docs/DIRETRIZES-SBD-2015-2016.pdf. 6. World Health Organization. Technical Report: Definition and diagnosis of diabetes mellitus and impairment glycaemic regulation. Genebra: OMS, 2006.

7. Brasil. Ministério da Saúde. Secretaria de Atenção à Saúde. Cadernos de Atenção Básica - Diabetes. Ministério da Saúde, Brasília, 2006.

8. Nathan DM, DCCT/Edic Research Group. The diabetes control and complications trial/epidemiology of diabetes interventions and complications study at 30 years: overview. Diabetes care. 2014 Jan 1;37(1):9-16.

9. Hagenmeyer EG, Koltermann KC, Dippel FW, Schädlich PK. Health economic evaluations comparing insulin glargine with NPH insulin in patients with type 1 diabetes: a systematic review. Cost Effectiveness and Resource Allocation. 2011 Oct 6;9(1):15.

10. Suh DC, Aagren M. Cost-effectiveness of insulin detemir: a systematic review. Expert Review of Pharmacoeconomics \& Outcomes Research. 2011 11(6):641-655. 11. Ericsson $\AA$, Pollock RF, Hunt B, Valentine WJ. Evaluation of the cost-utility of insulin degludec vs insulin glargine in Sweden. Journal of medical economics. 2013 Dec 1;16(12):1442-52. 
12. Guillermin AL, Samyshkin Y, Wright D, Nguyen T, Villeneuve J. Modeling the lifetime costs of insulin glargine and insulin detemir in type 1 and type 2 diabetes patients in Canada: a meta-analysis and a cost-minimization analysis. Journal of medical economics. 2011 Jan 1;14(2):207-16.

13. Roze S, Smith-Palmer J, Valentine W, Portu S, Nørgaard K, Pickup JC. Costeffectiveness of continuous subcutaneous insulin infusion versus multiple daily injections of insulin in Type 1 diabetes: a systematic review. Diabetic Medicine. 2015 Nov $1 ; 32(11): 1415-24$.

14. Brändle M, Herman WH. The CORE Diabetes Model. Curr Med Res Opin. 2004 Aug;20 Suppl 1:S1-3.

15. Palmer AJ, Roze S, Valentine WJ, Minshall ME, Foos V, Lurati FM et al. The CORE Diabetes Model: Projecting long-term clinical outcomes, costs and costeffectiveness of interventions in diabetes mellitus (types 1 and 2) to support clinical and reimbursement decision-making. Curr Med Res Opin. 2004 Aug;20 Suppl 1:S526.

16. Thokala P, Kruger J, Brennan A, Basarir H, Duenas A, Pandor A, Gillett M, Elliott J, Heller S. Assessing the cost-effectiveness of type 1 diabetes interventions: the Sheffield type 1 diabetes policy model. Diabet Med. 2014 Apr;31(4):477-86. 17. World Health Organization. Technical Report: Definition and diagnosis of diabetes mellitus and impairment glycaemic regulation. Genebra: OMS, 2006. 18. Gomes MB, Negrato CA, Cobas R, Tannus LR, Gonçalves PR, da Silva PC, Carneiro JR, Matheus AS, Dib SA, Azevedo MJ, Nery M. Determinants of intensive insulin therapeutic regimens in patients with type 1 diabetes: data from a nationwide multicenter survey in Brazil. Diabetology \& metabolic syndrome. 2014 May $31 ; 6(1): 67$.

19. Harjutsalo V, Forsblom C, Groop PH. Time trends in mortality in patients with type 1 diabetes: nationwide population based cohort study. BMJ. 2011 Sep 8;343:d5364.

20. The Diabetes Control and Complications Trial Research Group. The effect of intensive diabetes therapy on the development and progression of neuropathy. Ann Intern Med 1995; 122: 561-568.

21. Silva SB, Caulliraux HM, Araújo CA, Rocha E. Uma comparação dos custos do transplante renal em relação às diálises no Brasil. Cad. Saúde Pública. 2016 Jun;32(6):e00013515. 
22. Dalla PL, Faglia E. Treatment of diabetic foot ulcer: an overview strategies for clinical approach. Curr Diabetes Rev. 2006 Nov;2(4):431-47.

23. Apelqvist $\mathrm{J}$, Larsson $\mathrm{J}$. What is the most effective way to reduce incidence of amputation in the diabetic foot? Diabetes Metab Res Rev 2000 Sep-Oct;16 Suppl 1:S75-83.

24. Rezende KF, Nunes MA, Melo NH, Malerbi D, Chacra AR, Ferraz MB. Internações por pé diabético: comparação entre o custo direto estimado e o desembolso do SUS. Arquivos Brasileiros de Endocrinologia \& Metabologia. 2008 Apr 1; 52(3):523-530.

25. Brasil. Ministério da Saúde. Secretaria de Ciência, Tecnologia e Insumos Estratégicos. Departamento de Ciência e Tecnologia. Diretrizes Metodológicas de Avaliação Econômica. - 2. ed. - Brasília: Ministério da Saúde, 2014.

26. Husereau D, Drummond M, Petrou S, Carswell C, Moher D, Greenberg D et al. Consolidated health economic evaluation reporting standards (CHEERS) statement. Cost Effectiveness and Resource Allocation. 2013 Mar 25;11(1):6.

27. BRASIL. Lei $n^{0} 11.347$, de 27 de setembro de 2006. Dispõe sobre o fornecimento de medicamentos e materiais necessários à sua aplicação e monitoramento da glicemia capilar aos portadores de diabetes inscritos em programas de educação para diabéticos. Diário Oficial da União de 28/9/2006.

28. Laranjeira FO, Silva EN, Pereira MG. Budget Impact of Long-Acting Insulin Analogues: The Case in Brazil. PLoS ONE 2016; 11(12): e0167039. doi:10.1371/journal.pone.0167039.

29. Fullerton B, Siebenhofer A, Jeitler K, Horvath K, Semlitsch T, Berghold A, Plank J, Pieber TR, Gerlach FM. Short-acting insulin analogues versus regular human insulin for adults with type 1 diabetes mellitus. The Cochrane Library. 2016 Jan 1. 30. Weissberg-Benchell J, Antisdel-Lomaglio J, Seshadri R. Insulin pump therapy. Diabetes care. 2003 Apr 1;26(4):1079-87.

32. Laranjeira FO, Petramale CA. A avaliação econômica em saúde na tomada de decisão: a experiência da CONITEC. BIS, Bol. Inst. Saúde. 2013 Maio;14(2):165170.

33. Instituto Nacional de Geografia e Estatística. PIB per capita. Disponível em: http://brasilemsintese.ibge.gov.br/contas-nacionais/pib-per-capita.html. Acessado em: 05/02/2017. 


\section{CONCLUSÃO}

Esta tese contém avaliação de tecnologias em saúde voltadas para o controle do diabetes tipo1, que abrange análise de efetividade, do impacto orçamentário e de custo-efetividade. Os resultados dessa avaliação constituem suporte para apoiar a decisão dos gestores em saúde no Brasil sobre este tema.

$\mathrm{Na}$ overview de revisões sistemáticas, método considerado nos dias de hoje como o de maior nível de evidência para intervenções em terapia, realizamos ampla revisão sobre as insulinas análogas de longa duração. Realizar tal estudo se mostrou um desafio, posto que o método das overviews ainda não está bem delimitado e as orientações para sua produção ainda se fundem com aquelas para revisões sistemáticas convencionais. Os resultados apontaram para eficácia das insulinas análogas de longa duração em comparação à insulina humana NPH, no que tange à redução de hipoglicemias e manutenção do controle glicêmico.

$\mathrm{Na}$ análise de impacto orçamentário, utilizamos uma nova abordagem ainda não praticada no País, o poder de barganha, que trouxe visão mais racional para as decisões de cobertura de novas tecnologias no sistema de saúde. Em nossa análise, tendo por base o poder de barganha, as insulinas análogas de longa duração apresentaram impacto orçamentário menor que o calculado pelo Ministério da Saúde do Brasil.

Já na análise de custo-efetividade, os resultados mostraram que a associação entre insulinas humanas e análogas é a mais custo-efetiva no contexto do Sistema Único de Saúde. No entanto, como essa opção já está coberta pelo SUS, a alternativa que despertou interesse foi a associação entre as insulinas análogas de longa duração e a de ação rápida, segunda posição com respeito à razão incremental de custo-efetividade.

Generalizadamente, os resultados dos três estudos apresentados apontam para benefício em efetividade e eficiência das insulinas análogas.

No âmbito econômico, nosso principal trunfo metodológico se traduz no poder de barganha, aplicado em ambas as análises, de impacto orçamentário e de custoefetividade. Nesse contexto, é importante destacar que a bomba de insulina foi a opção terapêutica que evidenciou maior ganho em anos de vida ajustados por qualidade e redução das complicações. No entanto, como não utilizamos a redução 
de preço advinda do poder de negociação, ela alcançou a pior posição na análise de custo-efetividade.

No que concerne à barganha é importante frisar que, no Brasil, a negociação de preços ainda não faz parte do processo formal de decisão para a incorporação de novas tecnologias em saúde. A lei e o decreto que instituíram a Comissão Nacional de Incorporação de Tecnologias no SUS - CONITEC - não contemplam essa etapa fundamental da decisão. Logo, o que se observa são decisões baseadas em preços irreais, em geral altos demais, face à extensa demanda do SUS. O problema é de mão dupla: nas decisões negativas devido ao alto impacto orçamentário, a população deixa de receber tratamentos eficazes por falta de negociação de preços. Nos casos das decisões positivas, o Ministério da Saúde opta por incorporar tecnologias a preços elevados, os quais poderiam onerar menos o sistema caso fossem negociados.

À vista disso, pode-se perceber que a CONITEC tem potencial para aumentar sua abrangência de atuação no que diz respeito a considerar a negociação de preço antes da decisão de incorporação de novas tecnologias, produzindo assim recomendações mais racionais e mais favoráveis ao sistema.

Outro fator importante no que diz respeito à tomada de decisão de cobertura no sistema de saúde é a produção de protocolos assistenciais mais realistas, no sentido de uma utilização racional das tecnologias. Como descrito no artigo sobre análise de impacto orçamentário, é essencial restringir as indicações, a fim de alcançar a parcela da população que mais se beneficiaria com as tecnologias de alto-custo. A partir da determinação de nichos específicos de utilização para cada fármaco ou produto, previne-se que o impacto orçamentário seja aumentado irracionalmente devido a falhas de prescrição.

Uma avaliação de tecnologias visa responder a, pelo menos, três perguntas. A tecnologia é eficaz? Esta tese, em sua primeira parte, conseguiu mostrar que as insulinas análogas de longa duração são eficazes quando comparadas à NPH. Vale a pena economicamente? Esta questão foi abordada nas partes seguintes da tese, que revelaram que essas insulinas podem ter um custo acessível, se este custo for negociado. Para quem a tecnologia é eficaz? Esta questão não foi objetivo da tese. No entanto, podemos pensar em recomendações para a pesquisa, como análise de subgrupos, que identifique a parcela da população que mais se beneficiaria com o uso de insulinas análogas de longa duração. Além disso, outros estudos necessários 
seriam overview sobre a efetividade das bombas de insulina, novo cálculo de custoefetividade considerando a barganha para essa tecnologia e seu impacto orçamentário. Dessa forma, pode-se aumentar o escopo dessa avaliação, trazendo informações importantes para a tomada de decisão com relação aos tratamentos para diabetes tipo 1 no Brasil e aumentando o acesso dos pacientes a novas tecnologias. 


\section{APÊNDICE A}

Search strategy applied to EMBASE and Cochrane Library.

\begin{tabular}{|l|l|}
\hline DATABASE & SEARCH STRATEGY \\
\hline EMBASE & $\begin{array}{l}\text { 'insulin dependent diabetes mellitus'/mj OR 'insulin dependent diabetes } \\
\text { mellitus' OR 'type 1 diabetes':ab,ti OR 'diabetes mellitus type 1':ab,ti OR } \\
\text { 'diabetes type 1':ab,ti OR t1d:ab,ti AND ('long-acting insulin analogue':ab,ti } \\
\text { OR 'long acting insulin analogue':ab,ti OR 'long-acting insulin analog*':ab,ti } \\
\text { OR 'long-acting analog* insulin':ab,ti OR glargine:ab,ti OR lantus:ab,ti OR } \\
\text { 'hoe 901':ab,ti OR detemir:ab,ti OR levemir:ab,ti OR nn304:ab,ti OR } \\
\text { degludec:ab,ti OR 'insulin degludec':ab,ti) AND ([cochrane review]/lim OR } \\
\text { [systematic review]/lim OR [meta analysis]/lim) AND ([english]/lim OR } \\
\text { [portuguese]/lim OR [spanish]/lim) }\end{array}$ \\
\hline Cochrane Library & $\begin{array}{l}\text { type 1 diabetes (Title, Abstract, Keywords) AND long acting insulin analogue } \\
\text { (Search All Text) }\end{array}$ \\
\hline
\end{tabular}




\section{APÊNDICE B}

Characteristics of included systematic reviews.

\begin{tabular}{|c|c|c|}
\hline STUDY & DESIGN & $\begin{array}{l}\text { INTERVENTION VS } \\
\text { COMPARATOR }\end{array}$ \\
\hline Wang et al., 2003 (1) & $\begin{array}{l}\text { Systematic review without meta- } \\
\text { analysis }\end{array}$ & Glargine vs NPH \\
\hline Warren et al., 2004 (2) & Health Technology Assessment & Glargine vs NPH \\
\hline Mullins et al., 2007 (3) & $\begin{array}{l}\text { Systematic review with meta- } \\
\text { analysis (Negative Binomial } \\
\text { Meta-Regression Analysis) }\end{array}$ & Glargine vs NPH \\
\hline Tran et al., 2007 (4) & Health Technology Assessment & $\begin{array}{l}\text { Long-acting insulin analogues } \\
\text { vs NPH }\end{array}$ \\
\hline Vardi et al., 2008 (5) & $\begin{array}{l}\text { Systematic review with meta- } \\
\text { analysis }\end{array}$ & $\begin{array}{l}\text { Long-acting insulin analogues } \\
\text { vs NPH }\end{array}$ \\
\hline Singh et al., 2009 (6) & $\begin{array}{l}\text { Systematic review with meta- } \\
\text { analysis }\end{array}$ & $\begin{array}{l}\text { Insulin analogues vs human } \\
\text { insulins }\end{array}$ \\
\hline Sanches et al., 2011 (7) & Mixed treatment comparison & $\begin{array}{l}\text { Long-acting insulin analogues } \\
\text { vs NPH }\end{array}$ \\
\hline $\begin{array}{l}\text { Szypowska et al., } 2011 \\
\text { (8) }\end{array}$ & $\begin{array}{l}\text { Systematic review with meta- } \\
\text { analysis }\end{array}$ & Detemir vs NPH \\
\hline Frier et al., 2013 (9) & $\begin{array}{l}\text { Systematic review without meta- } \\
\text { analysis }\end{array}$ & Detemir vs NPH \\
\hline $\begin{array}{l}\text { Caires de Souza et al., } \\
2014(10)\end{array}$ & $\begin{array}{l}\text { Systematic review without meta- } \\
\text { analysis }\end{array}$ & Glargine vs NPH \\
\hline Tricco et al., 2014 (11) & Network meta-analysis & $\begin{array}{l}\text { Long-acting insulin analogues } \\
\text { vs NPH }\end{array}$ \\
\hline
\end{tabular}




\section{REFERÊNCIAS}

1. Wang F, Carabino JM, Vergara CM. Insulin glargine: a systematic review of a long-acting insulin analogue. Clin Ther. 2003 Jun;25(6):1541-77.

2. Warren E. Weatherley-Jones E. Chilcott J. Beverley C. Systematic review and economic evaluation of a long-acting insulin analogue, insulin glargine. Health Technology Assessment 2004 8(45):iii-41.

3. Mullins P. Sharplin P. Yki-Jarvinen H. Riddle M.C. Haring H.-U. Negative Binomial Meta-Regression Analysis of Combined Glycosylated Hemoglobin and Hypoglycemia Outcomes Across Eleven Phase III and IV Studies of Insulin Glargine Compared with Neutral Protamine Hagedorn Insulin in Type 1 and Type 2 Diabetes Mellitus. Clinical Therapeutics 2007; 29(8): 1607-1619.

4. Tran K, Banerjee S, Li H, Cimon K, Daneman D, Simpson SH, Campbell K. Long-acting insulin analogues for diabetes mellitus: meta-analysis of clinical outcomes and assessment of cost-effectiveness [Technology Report number 92]. Ottawa: Canadian Agency for Drugs and Technologies in Health; 2007.

5. Vardi M. Jacobson E. Nini A. Bitterman H. Intermediate acting versus long acting insulin for type 1 diabetes mellitus. Cochrane Database of Systematic Reviews (2008):3. Article Number: CD006297.

6. Singh S.R. Ahmad F. Lal A. Yu C. Bai Z. Bpharm H.B. Efficacy and safety of insulin analogues for the management of diabetes mellitus: A meta-analysis. CMAJ 2009;180(4): 385-397.

7. Sanches AC, Correr CJ, Venson R, Pontarolo R. Revisiting the efficacy of longacting insulin analogues on adults with type 1 diabetes using mixed-treatment comparisons. Diabetes Res Clin Pract. 2011.

8. Szypowska A, Golicki D, Groele L, Pańkowska E. Long-acting insulin analogue detemir compared with NPH insulin in type 1 diabetes: asystematic review and meta-analysis. Pol Arch Med Wewn. 2011 Jul-Aug;121(7-8):237-46.

9. Frier BM, Russell-Jones D, Heise T. A comparison of insulin detemir and neutral protamine Hagedorn (isophane) insulin in the treatment of diabetes: a systematic review. Diabetes Obes Metab. 2013 Nov;15(11):978-86.

10. Caires de Souza AL, de Assis Acurcio F, Guerra Júnior AA, Rezende Macedo do Nascimento RC, Godman B, Diniz LM. Insulin glargine in a Brazilian state: should 
the government disinvest? An assessment based on a systematic review. Appl Health Econ Health Policy. 2014 Feb;12(1):19-32.

11. Tricco A.C. Ashoor H.M. Antony J. Beyene J. Veroniki A.A. Isaranuwatchai W. Harrington A. Wilson C. Tsouros S. Soobiah C. Yu C.H. Hutton B. Hoch J.S. Hemmelgarn B.R. Moher D. Majumdar S.R. Straus S.E. Safety, effectiveness, and cost effectiveness of long acting versus intermediate acting insulin for patients with type 1 diabetes: Systematic review and network meta-analysis. BMJ (Online) 2014 Oct 1. 349: g5459. 


\section{APÊNDICE C}

Characteristics of excluded systematic reviews.

\begin{tabular}{|l|l|l|l|}
\hline \multicolumn{1}{|c|}{ STUDY } & \multicolumn{1}{|c|}{ DESIGN } & \multicolumn{1}{c|}{$\begin{array}{c}\text { INTERVENTION VS } \\
\text { COMPARATOR }\end{array}$} & \multicolumn{1}{|c|}{$\begin{array}{c}\text { REASON FOR } \\
\text { EXCLUSION }\end{array}$} \\
\hline $\begin{array}{l}\text { DeWitt \& Hirsch, 2003 } \\
\text { (1) }\end{array}$ & Review & Insulin therapy & Type of study \\
\hline Palmer et al., 2004 (2) & $\begin{array}{l}\text { Cost-effectiveness } \\
\text { analysis and meta- } \\
\text { analysis, but without } \\
\text { systematic review }\end{array}$ & Detemir vs NPH & Type of study \\
\hline Gough et al., 2007 (3) & Review & Insulin analogues & Type of study \\
\hline $\begin{array}{l}\text { Monami et al., 2009 } \\
\text { (4) }\end{array}$ & $\begin{array}{l}\text { Meta-analysis without } \\
\text { systematic review }\end{array}$ & $\begin{array}{l}\text { Long-acting insulin } \\
\text { analogues vs NPH }\end{array}$ & Type of study \\
\hline $\begin{array}{l}\text { Hermansen et al., } \\
2009 \text { (5) }\end{array}$ & $\begin{array}{l}\text { Systematic review } \\
\text { (Conference abstract) }\end{array}$ & Detemir vs NPH & Conference abstract \\
\hline No authors, 2009 (6) & Review & $\begin{array}{l}\text { Long-acting insulin } \\
\text { analogues }\end{array}$ & Type of study \\
\hline Garg et al., 2010 (7) & $\begin{array}{l}\text { Review } \\
\text { Defudy }\end{array}$ \\
\hline Pieber et al., 2010 (8) & $\begin{array}{l}\text { Systematic review } \\
\text { (Conference abstract) }\end{array}$ & Detemir vs NPH & Conference abstract \\
\hline Bahia et al., 2013 (9) & $\begin{array}{l}\text { Systematic review } \\
\text { (Conference abstract) }\end{array}$ & $\begin{array}{l}\text { Long-acting insulin } \\
\text { analogues vs NPH }\end{array}$ & Conference abstract \\
\hline Slabu et al., 2014 (10) & $\begin{array}{l}\text { Systematic review } \\
\text { (Conference abstract) }\end{array}$ & $\begin{array}{l}\text { Long-acting insulin } \\
\text { analogues vs NPH }\end{array}$ & Conference abstract \\
\hline $\begin{array}{l}\text { Dawoud et al., 2015 } \\
\text { (11) }\end{array}$ & $\begin{array}{l}\text { Systematic review } \\
\text { (Conference abstract) }\end{array}$ & Basall insulin regimens & Conference abstract \\
\hline $\begin{array}{l}\text { Guerra-Junior et al., } \\
\text { 2015 (12) }\end{array}$ & $\begin{array}{l}\text { Systematic review } \\
\text { (Conference abstract) }\end{array}$ & $\begin{array}{l}\text { Long-acting insulin } \\
\text { analogues vs NPH }\end{array}$ & Conference abstract \\
\hline
\end{tabular}




\section{REFERÊNCIAS}

1. DeWitt DE, Hirsch IB. Outpatient insulin therapy in type 1 and type 2 diabetes mellitus: scientific review. JAMA 2003 May 7;289(17):2254-64.

2. Palmer AJ, Roze S, Valentine WJ, Smith I, Wittrup-Jensen KU. Costeffectiveness of detemir-based basal/bolus therapy versus NPH-based basal/bolus therapy for type 1 diabetes in a UK setting: an economic analysis based on meta-analysis results of four clinical trials. Curr Med Res Opin. 2004 Nov;20(11):1729-46.

3. Gough SC. A review of human and analogue insulin trials. Diabetes Research and Clinical Practice 2007; 77(1), 1-15.

4. Monami M, Marchionni N, Mannucci E. Long-acting insulin analogues vs. NPH human insulin in type 1 diabetes. A meta-analysis. Diabetes Obes Metab. 2009 Apr;11(4):372-8.

5. Hermansen K, Heller S, Andersen M, Russell-Jones DL. Insulin detemir reduces hypoglycemic risk at comparable HbAlc values compared to NPH Insulin in patients with type 1 diabetes. Diabetes 2009; 58(SUPPL. 1A).

6. No authors. Insulin analogues of marginal, if any, benefit. Journal of the National Medical Association 2009; 101(8):822-823.

7. Garg S, Moser E, Dain MP, Rodionova A. Clinical experience with insulin glargine in type 1 diabetes. Diabetes Technol Ther. 2010 Nov;12(11):835-46. doi: 10.1089/dia.2010.0135.

8. Pieber TR, Heller S, Gong Y, Zhang K, Nattrass M. Insulin detemir is associated with a lower risk of overall and nocturnal hypoglycemia compared with neutral protamine hagedorn insulin-a meta-analysis of randomized clinical trials in type 1 diabetes. Diabetes 2010.

9. Bahia L.R. Cramer H. Lassance M. Santos B. Tura B. Long- acting insulin analogues for type 1 diabetes mellitus: A systematic review and meta-analysis. Diabetes 2013; 62(SUPPL.1):A239.

10. Slabu $\mathrm{H}$, Senior PA. Fasting glucose targets are not achieved in (treat to target) trials of basal insulin analogues: Systematic review of trials in type 1 diabetes. Diabetes 2013; 62(SUPPL. 1):A245. 
11. Dawoud D, Fenu E, Wonderling D, O'Mahony R, Pursey N, Cobb J, Amiel SA, Higgins B. Basal insulin regimens: Systematic review, network meta-analysis, and cost-utility analysis for the National Institute for Health and Care Excellence (NICE) Clinical guideline on type 1 diabetes mellitus in adults. Value in Health 2015; 18(7):A339.

12. Guerra-Junior AA, Araujo VE, Izidoro JB, Diniz LM, Silva MR, Mata AR, Nascimento RC, Alvares J, Acurcio FA. Efficacy and safety of insulin analogues compared to human insulin preparations for the treatment of patients with diabetes type 1 (DM1): Systematic review and meta-analysis. Value in Health 2015; 18(3):A55 . 


\section{APÊNDICE D}

Characteristics of included randomized clinical trials.

\begin{tabular}{|c|c|c|c|c|c|c|c|}
\hline STUDY & JADAD & POPULATION & $\begin{array}{l}\text { TREATMENT } \\
\text { PERIOD } \\
\text { (weeks) }\end{array}$ & $\begin{array}{l}\text { INTERVENTION VS } \\
\text { COMPARATOR } \\
\text { (daily frequency) }\end{array}$ & SAMPLE SIZE & BOLUS & OUTCOMES \\
\hline Raskin et al., 2000 & 3 & Adults & 16 & Glargine (od) vs NPH (od or bid) & 310 vs 309 & Lispro & $\begin{array}{l}\text { General hypoglycemia } \\
\text { Severe hypoglycemia } \\
\text { Nocturnal hypoglycemia } \\
\text { A1C }\end{array}$ \\
\hline Ratner et al., 2000 & 2 & Adults & 28 & Glargine (od) vs NPH (od or bid) & 264 vs 270 & Regular & $\begin{array}{l}\text { General hypoglycemia } \\
\text { Severe hypoglycemia } \\
\text { Nocturnal hypoglycemia } \\
\text { A1C }\end{array}$ \\
\hline $\begin{array}{l}\text { Hermansen et al, } \\
2001\end{array}$ & 2 & Adults & 12 & Detemir (od) vs NPH (od) & 57 vs 56 & Regular & $\begin{array}{l}\text { General hypoglycemia } \\
\text { Severe hypoglycemia } \\
\text { Nocturnal hypoglycemia }\end{array}$ \\
\hline $\begin{array}{l}\text { Schober et al., } \\
2002\end{array}$ & 3 & Children & 28 & Glargine (od) vs NPH (od or bid) & 175 vs 175 & Regular & A1C \\
\hline Vague et al., 2003 & 3 & Adults & 26 & Detemir (bid) vs NPH (bid) & 301 vs 146 & Aspart & $\begin{array}{l}\text { General hypoglycemia } \\
\text { Severe hypoglycemia } \\
\text { Nocturnal hypoglycemia } \\
\text { A1C }\end{array}$ \\
\hline $\begin{array}{l}\text { Rossetti et al., } \\
2003\end{array}$ & 2 & Adults & 12 & Glargine (bid) vs NPH (4) & 17 vs 17 & Lispro & $\begin{array}{l}\text { General hypoglycemia } \\
\text { Nocturnal hypoglycemia } \\
\text { A1C }\end{array}$ \\
\hline Murphy et al., 2003 & 2 & Adolescents & 16 & Glargine (od) vs NPH (od) & 25 vs 25 & $\begin{array}{l}\text { Lispro vs } \\
\text { Regular }\end{array}$ & $\begin{array}{l}\text { General hypoglycemia } \\
\text { Nocturnal hypoglycemia } \\
\text { A1C }\end{array}$ \\
\hline $\begin{array}{l}\text { Hermansen et al., } \\
2004\end{array}$ & 2 & Adults & 12 & Detemir (bid) vs NPH (bid) & 298 vs 297 & $\begin{array}{l}\text { Aspart vs } \\
\text { Regular }\end{array}$ & $\begin{array}{l}\text { General hypoglycemia } \\
\text { Nocturnal hypoglycemia } \\
\text { A1C }\end{array}$ \\
\hline Home et al., 2004 & 3 & Adults & 12 & Detemir (bid) vs NPH (bid) & 276 vs 132 & Aspart & $\begin{array}{l}\text { General hypoglycemia } \\
\text { Severe hypoglycemia } \\
\text { Nocturnal hypoglycemia } \\
\text { A1C }\end{array}$ \\
\hline
\end{tabular}




\begin{tabular}{|c|c|c|c|c|c|c|c|}
\hline $\begin{array}{l}\text { Russel-Jones et } \\
\text { al., } 2004\end{array}$ & 3 & Adults & & Detemir (od) vs NPH (od) & 491 vs 256 & Regular & $\begin{array}{l}\text { General hypoglycemia } \\
\text { Severe hypoglycemia } \\
\text { Nocturnal hypoglycemia } \\
\text { A1C }\end{array}$ \\
\hline Standl et al., 2004 & 2 & Adul & & Detemir (bid) vs NPH (bid) & 154 vs 135 & Regular & $\begin{array}{l}\text { General hypoglycemia } \\
\text { Severe hypoglycemia } \\
\text { Nocturnal hypoglycemia } \\
\text { A1C }\end{array}$ \\
\hline $\begin{array}{l}\text { Porcellatti et al., } \\
2004\end{array}$ & 3 & Adults & 52 & Glargine (od) vs NPH & 61 vs 60 & Lispro & $\begin{array}{l}\text { General hypoglycemia } \\
\text { Nocturnal hypoglycemia } \\
\text { A1C }\end{array}$ \\
\hline NN304-1476 & 2 & Adults & 44 & $\begin{array}{l}\text { Detemir (od or bid) vs NPH (od } \\
\text { or bid) }\end{array}$ & 178 vs 95 & Aspart & $\begin{array}{l}\text { General hypoglycemia } \\
\text { Nocturnal hypoglycemia } \\
\text { A1C }\end{array}$ \\
\hline Home et al., 2005 & 3 & Adults & 28 & Glargine (od) vs NPH (od or bid) & 292 vs 293 & Regular & A1C \\
\hline Pieber et al., 2005 & 2 & Adults & 12 & Detemir (bid) vs NPH (bid) & 271 vs 129 & Aspart & $\begin{array}{l}\text { General hypoglycemia } \\
\text { Severe hypoglycemia } \\
\text { Nocturnal hypoglycemia } \\
\text { A1C }\end{array}$ \\
\hline Fulcher et al., 2005 & 3 & Adults & 30 & Glargine (od) vs NPH (od) & 62 vs 63 & Lispro & $\begin{array}{l}\text { General hypoglycemia } \\
\text { Severe hypoglycemia } \\
\text { Nocturnal hypoglycemia } \\
\text { A1C }\end{array}$ \\
\hline $\begin{array}{l}\text { Kolendorf et al., } \\
2006\end{array}$ & 2 & Adults & 10 & Detemir (bid) vs NPH (bid) & 125 vs 128 & Aspart & $\begin{array}{l}\text { General hypoglycemia } \\
\text { Severe hypoglycemia } \\
\text { Nocturnal hypoglycemia } \\
\text { A1C }\end{array}$ \\
\hline Ashwell et al 2006 & 3 & Adults & 16 & Glargine (od) vs NPH (od or bid) & 51 vs 51 & $\begin{array}{l}\text { Lispro vs } \\
\text { Regular }\end{array}$ & $\begin{array}{l}\text { General hypoglycemia } \\
\text { Nocturnal hypoglycemia } \\
\text { A1C }\end{array}$ \\
\hline $\begin{array}{l}\text { Mianovska et al., } \\
2007\end{array}$ & 2 & Children & 24 & Glargine (od) vs NPH & 14 vs 14 & $\begin{array}{l}\text { Lispro or } \\
\text { Regular }\end{array}$ & A1C \\
\hline $\begin{array}{l}\text { Robertson et al., } \\
2007\end{array}$ & 3 & $\begin{array}{l}\text { Children and } \\
\text { adolescents }\end{array}$ & 26 & $\begin{array}{l}\text { Detemir (od or bid) vs NPH (od } \\
\text { or bid) }\end{array}$ & 232 vs 115 & Aspart & $\begin{array}{l}\text { General hypoglycemia } \\
\text { Severe hypoglycemia } \\
\text { Nocturnal hypoglycemia } \\
\text { A1C }\end{array}$ \\
\hline $\begin{array}{l}\text { Chatterjee et al., } \\
2007\end{array}$ & 3 & Adults & 16 & Glargine (od) vs NPH (bid) & 57 vs 57 & Aspart & $\begin{array}{l}\text { General hypoglycemia } \\
\text { Severe hypoglycemia } \\
\text { Nocturnal hypoglycemia } \\
\text { A1C }\end{array}$ \\
\hline Bartley et al., 2008 & 3 & Adults & 104 & Detemir (od) vs NPH (od) & 331 vs 164 & Aspart & General hypoglycemia \\
\hline
\end{tabular}




\begin{tabular}{|c|c|c|c|c|c|c|c|}
\hline & & & & & & & $\begin{array}{l}\text { Severe hypoglycemia } \\
\text { Nocturnal hypoglycemia } \\
\text { A1C }\end{array}$ \\
\hline Chase et al., 2008 & 2 & Adolescents & 24 & $\begin{array}{l}\text { Glargine (od) vs NPH or Lente } \\
\text { (bid) }\end{array}$ & 85 vs 90 & Lispro & $\begin{array}{l}\text { General hypoglycemia } \\
\text { Severe hypoglycemia } \\
\text { A1C }\end{array}$ \\
\hline Hassan et al., 2008 & 3 & $\begin{array}{l}\text { Children and } \\
\text { adolescents }\end{array}$ & & Glargine (bid) vs NPH (bid) & 19 vs 17 & $\begin{array}{l}\text { Lispro or } \\
\text { Aspart }\end{array}$ & $\begin{array}{l}\text { General hypoglycemia } \\
\text { A1C }\end{array}$ \\
\hline Bolli et al., 2009 & 2 & Adults & 24 & Glargine (od) vs NPH (bid or + ) & 85 vs 90 & Lispro & $\begin{array}{l}\text { General hypoglycemia } \\
\text { Severe hypoglycemia } \\
\text { A1C }\end{array}$ \\
\hline Danne et al., 2013 & 5 & Children & 24 & Glargine (od) vs NPH (od or bid) & 61 vs 64 & $\begin{array}{l}\text { Lispro or } \\
\text { Regular }\end{array}$ & $\begin{array}{l}\text { General hypoglycemia } \\
\text { Nocturnal hypoglycemia } \\
\text { A1C }\end{array}$ \\
\hline $\begin{array}{l}\text { Thalange et al., } \\
2013\end{array}$ & 3 & Children & 52 & $\begin{array}{l}\text { Detemir (od or bid) vs NPH (od } \\
\text { or bid) }\end{array}$ & 177 vs 170 & Aspart & $\begin{array}{l}\text { General hypoglycemia } \\
\text { Nocturnal hypoglycemia }\end{array}$ \\
\hline $\begin{array}{l}\text { Pedersen- } \\
\text { Bjergaard et al., } \\
2014\end{array}$ & 4 & Adults & 52 & Detemir (od) vs NPH & 133 vs 139 & $\begin{array}{l}\text { Aspart vs } \\
\text { Regular }\end{array}$ & $\begin{array}{l}\text { General hypoglycemia } \\
\text { Severe hypoglycemia }\end{array}$ \\
\hline
\end{tabular}




\section{APÊNDICE E}

Characteristics of excluded randomized clinical trials.

\begin{tabular}{|c|c|c|c|}
\hline STUDY & DESIGN & $\begin{array}{l}\text { INTERVENTION VS } \\
\text { COMPARATOR }\end{array}$ & $\begin{array}{l}\text { REASON FOR } \\
\text { EXCLUSION }\end{array}$ \\
\hline $\begin{array}{l}\text { Rosenstock et al., } \\
2000 \text { (1) }\end{array}$ & Phase 2 RCT & $\begin{array}{l}\text { Glargine } 30 \text { and } \\
80 \mu \mathrm{g} / \mathrm{ml} \text { vs NPH }\end{array}$ & $\begin{array}{l}\text { Type of study (Phase } \\
\text { 2) }\end{array}$ \\
\hline Pieber et al., 2000 (2) & Phase 2 RCT & $\begin{array}{l}\text { Glargine } 30 \text { and } \\
80 \mu \mathrm{g} / \mathrm{ml} \text { vs NPH }\end{array}$ & $\begin{array}{l}\text { Type of study (Phase } \\
\text { 2) }\end{array}$ \\
\hline $\begin{array}{l}\text { Van Dyk et al., } 2000 \\
\text { (3) }\end{array}$ & (Conference abstract) & Glargine & Conference abstract \\
\hline $\begin{array}{l}\text { Hershon et al., 2001a } \\
\text { (4) } \\
\text { (Same population as } \\
\text { Hershon et al., } 2004 \\
\text { (5)) }\end{array}$ & $\begin{array}{l}\text { Phase 3 RCT } \\
\text { (Conference abstract) }\end{array}$ & Glargine vs NPH & $\begin{array}{l}\text { Conference abstract } \\
\text { reporting the same } \\
\text { population as an } \\
\text { included reference }\end{array}$ \\
\hline $\begin{array}{l}\text { Hershon et al., 2001b } \\
\text { (6) } \\
\text { (Same population as } \\
\text { Hershon et al., 2004) }\end{array}$ & $\begin{array}{l}\text { Phase } 3 \text { RCT } \\
\text { (Conference abstract) }\end{array}$ & Glargine vs NPH & $\begin{array}{l}\text { Conference abstract } \\
\text { reporting the same } \\
\text { population as an } \\
\text { included reference }\end{array}$ \\
\hline Garg et al., 2001 (7) & Conference abstract & Glargine vs NPH & Type of study \\
\hline $\begin{array}{l}\text { Withaus et al., } 2001 \\
\text { (8) } \\
\text { (Same population as } \\
\text { Pieber et al., 2000) }\end{array}$ & $\begin{array}{l}\text { Phase 3 RCT } \\
\text { Assessed satisfaction } \\
\text { and well-being in } \\
\text { patients from a previous } \\
\text { clinical trial }\end{array}$ & Glargine vs NPH & Unsuitable outcome \\
\hline $\begin{array}{l}\text { Roberts et al., } 2001 \\
\text { (9) } \\
\text { (Same population as } \\
\text { Standl et al., } 2004 \\
(10) \text { ) }\end{array}$ & $\begin{array}{l}\text { Phase } 3 \text { RCT } \\
\text { (Conference abstract) }\end{array}$ & Detemir vs NPH & $\begin{array}{l}\text { Conference abstract } \\
\text { reporting the same } \\
\text { population as an } \\
\text { included reference }\end{array}$ \\
\hline $\begin{array}{l}\text { Standl et al., } 2002 \\
\text { (Same population as } \\
\text { Standl et al., 2004) }\end{array}$ & $\begin{array}{l}\text { Phase } 3 \text { RCT } \\
\text { (Conference abstract) }\end{array}$ & Detemir vs NPH & $\begin{array}{l}\text { Conference abstract } \\
\text { reporting the same } \\
\text { population as an } \\
\text { included reference }\end{array}$ \\
\hline $\begin{array}{l}\text { Standl et al., } 2002 \\
\text { (Same population as } \\
\text { Standl et al., 2004) }\end{array}$ & $\begin{array}{l}\text { Phase 3 RCT } \\
\text { (Conference abstract) }\end{array}$ & Detemir vs NPH & $\begin{array}{l}\text { Conference abstract } \\
\text { reporting the same } \\
\text { population as an } \\
\text { included reference }\end{array}$ \\
\hline $\begin{array}{l}\text { Porcellati et al., } 2002 \\
\text { (11) } \\
\text { (Same population as } \\
\text { Porcellati et al., } 2004 \\
\text { (12)) }\end{array}$ & $\begin{array}{l}\text { Phase 3 RCT } \\
\text { (Conference abstract) }\end{array}$ & Glargine vs NPH & $\begin{array}{l}\text { Conference abstract } \\
\text { reporting the same } \\
\text { population as an } \\
\text { included reference }\end{array}$ \\
\hline $\begin{array}{l}\text { Standl et al., } 2003 \\
\text { (Same population as } \\
\text { Standl et al., 2004) }\end{array}$ & $\begin{array}{l}\text { Phase 3 RCT } \\
\text { (Conference abstract) }\end{array}$ & Detemir vs NPH & $\begin{array}{l}\text { Conference abstract } \\
\text { reporting the same } \\
\text { population as an } \\
\text { included reference }\end{array}$ \\
\hline $\begin{array}{l}\text { Home et al., } 2003 \text { (13) } \\
\text { (Same population as } \\
\text { Home et al., } 2004 \\
(14) \text { ) }\end{array}$ & $\begin{array}{l}\text { Phase } 3 \text { RCT } \\
\text { (Conference abstract) }\end{array}$ & Detemir vs NPH & $\begin{array}{l}\text { Conference abstract } \\
\text { reporting the same } \\
\text { population as an } \\
\text { included reference }\end{array}$ \\
\hline Hershon et al., 2004 & Phase 3 RCT & Glargine vs NPH & Subgroup analysis of \\
\hline
\end{tabular}




\begin{tabular}{|c|c|c|c|}
\hline (28) & $\begin{array}{l}\text { Subgroup analysis of } \\
\text { Ratner et al. }\end{array}$ & & an included reference \\
\hline $\begin{array}{l}\text { Robertson et al., } 2004 \\
(15) \\
\text { (Same population as } \\
\text { Robertson et al., } 2007 \\
(16))\end{array}$ & $\begin{array}{l}\text { Phase 3 RCT } \\
\text { (Conference abstract) }\end{array}$ & Detemir vs NPH & $\begin{array}{l}\text { Conference abstract } \\
\text { reporting the same } \\
\text { population as an } \\
\text { included reference }\end{array}$ \\
\hline $\begin{array}{l}\text { Pieber et al., } 2004 \\
\text { (17) }\end{array}$ & $\begin{array}{l}\text { RCT } \\
\text { (Pharmacodynamic } \\
\text { study) }\end{array}$ & Detemir vs NPH & Type of study \\
\hline Doyle et al., 2004 (18) & Phase 3 RCT & CSII vs Glargine & Unsuitable comparator \\
\hline $\begin{array}{l}\text { Kølendorf et al., } 2004 \\
(19) \\
\text { (Same population as } \\
\text { Kølendorf et al., } 2006 \\
(20))\end{array}$ & Cross-over RCT & Detemir vs NPH & $\begin{array}{l}\text { Conference abstract } \\
\text { reporting the same } \\
\text { population as an } \\
\text { included reference }\end{array}$ \\
\hline $\begin{array}{l}\text { De Leeuw et al., } 2005 \\
\text { (21) }\end{array}$ & $\begin{array}{l}\text { Extension study, } 52 \\
\text { weeks, without } \\
\text { randomization }\end{array}$ & Detemir vs NPH & $\begin{array}{l}\text { Non-randomized } \\
\text { extension study }\end{array}$ \\
\hline $\begin{array}{l}\text { Kudva et al., } 2005 \\
\text { (22) }\end{array}$ & $\begin{array}{l}\text { Double-blind cross-over } \\
\text { RCT } \\
\text { (Jadad 5) }\end{array}$ & Glargine vs Ultralente & Unsuitable comparator \\
\hline $\begin{array}{l}\text { Davies et al., } 2005 \\
(23) \\
\text { (Same population as } \\
\text { Chatterjee et al., } 2007 \\
(24))\end{array}$ & $\begin{array}{l}\text { Cross-over RCT } \\
\text { (Conference abstract) }\end{array}$ & Glargine vs NPH & $\begin{array}{l}\text { Conference abstract } \\
\text { reporting the same } \\
\text { population as an } \\
\text { included reference }\end{array}$ \\
\hline $\begin{array}{l}\text { Kawamura et al., } 2005 \\
\text { (25) }\end{array}$ & $\begin{array}{l}\text { Cross-over RCT } \\
\text { (Conference abstract) }\end{array}$ & Glargine vs NPH & Conference abstract \\
\hline $\begin{array}{l}\text { Mianovska et al., } 2006 \\
\text { (26) } \\
\text { (Same population as } \\
\text { Mianovska et al., } 2007 \\
(27) \text { ) }\end{array}$ & $\begin{array}{l}\text { Cross-over RCT } \\
\text { (Conference abstract) }\end{array}$ & Glargine vs NPH & $\begin{array}{l}\text { Conference abstract } \\
\text { reporting the same } \\
\text { population as an } \\
\text { included reference }\end{array}$ \\
\hline $\begin{array}{l}\text { Chase et al., } 2006 \\
\text { (28) } \\
\text { (Same population as } \\
\text { Chase et al., } 2008 \\
(29) \text { ) }\end{array}$ & $\begin{array}{l}\text { Phase 3 RCT } \\
\text { (Conference abstract) }\end{array}$ & Glargine vs NPH & $\begin{array}{l}\text { Conference abstract } \\
\text { reporting the same } \\
\text { population as an } \\
\text { included reference }\end{array}$ \\
\hline $\begin{array}{l}\text { Bolli et al., } 2006(30) \\
\text { (Same population as } \\
\text { Bolli et al., } 2009(31) \text { ) }\end{array}$ & $\begin{array}{l}\text { Phase } 3 \text { RCT } \\
\text { (Conference abstract) }\end{array}$ & Glargine vs NPH & $\begin{array}{l}\text { Conference abstract } \\
\text { reporting the same } \\
\text { population as an } \\
\text { included reference } \\
\end{array}$ \\
\hline White et al., 2006 (32) & & & Unsuitable comparator \\
\hline Pesic et al., 2007 (33) & Phase 3 RCT & Glargine vs NPH & $\begin{array}{l}\text { Language (article in } \\
\text { Serbian, abstract in } \\
\text { English) }\end{array}$ \\
\hline $\begin{array}{l}\text { Pieber et al., } 2007 \\
\text { (34) }\end{array}$ & Phase 3 RCT & Detemir vs Glargine & Unsuitable comparator \\
\hline $\begin{array}{l}\text { Radman et al., } 2007 \\
\text { (35) }\end{array}$ & RCT & & Intervention \\
\hline $\begin{array}{l}\text { NN 304-1582, } 2007 \\
\text { (36) }\end{array}$ & Clinical trial protocol & Detemir vs NPH & No reported results \\
\hline NN 304-1689 (37) & $\begin{array}{l}\text { Non-randomized clinical } \\
\text { trial protocol about } \\
\text { safety }\end{array}$ & Detemir vs NPH & Type of study \\
\hline $\begin{array}{l}\text { NN 304-1595 (38) } \\
\text { (Same population as } \\
\text { Bartley et al., } 2008 \\
(39) \text { ) }\end{array}$ & $\begin{array}{l}\text { Non-inferiority RCT } \\
\text { (Clinical trial registry) }\end{array}$ & Detemir vs NPH & $\begin{array}{l}\text { Non-published trial } \\
\text { reporting the same } \\
\text { population as an } \\
\text { included reference }\end{array}$ \\
\hline
\end{tabular}




\begin{tabular}{|l|l|l|l|}
\hline NN 304-1604 (40) & $\begin{array}{l}\text { Phase 3 RCT } \\
\text { (Clinical trial registry) }\end{array}$ & Detemir vs NPH & Not enough data \\
\hline $\begin{array}{l}\text { Ashwell et al., 2008 } \\
\text { (41) } \\
\text { (Same population as } \\
\text { Ashwell et al., 2006 } \\
\text { (42)) }\end{array}$ & $\begin{array}{l}\text { Phase 3 RCT } \\
\text { Assessed satisfaction } \\
\text { quality of life in patients } \\
\text { from a previous clinical } \\
\text { trial }\end{array}$ & Glargine vs NPH & Unsuitable outcome \\
\hline $\begin{array}{l}\text { White et al., 2009 (43) } \\
\text { (Subgroup population } \\
\text { analysis of Chase et } \\
\text { al., 2008) }\end{array}$ & $\begin{array}{l}\text { Phase 3 RCT } \\
\text { (Subgroup analysis) }\end{array}$ & Glargine vs NPH & $\begin{array}{l}\text { Subgroup analysis of } \\
\text { an included reference }\end{array}$ \\
\hline $\begin{array}{l}\text { Zachariah et al., 2011 } \\
\text { (44) }\end{array}$ & Cross-over RCT & Detemir vs NPH & $\begin{array}{l}\text { Did not measure } \\
\text { outcomes in a suitable } \\
\text { way }\end{array}$ \\
\hline $\begin{array}{l}\text { Mathiesen et al., 2012 } \\
\text { (45) }\end{array}$ & $\begin{array}{l}\text { Non-inferiority RCT } \\
\text { (Pregnant T1D women) }\end{array}$ & Detemir vs NPH & Unsuitable population \\
\hline
\end{tabular}




\section{REFERÊNCIAS}

1. Rosenstock J, Park G, Zimmerman J, for the U.S. Insulin Glargine (HOE 901) Type 1 Diabetes Investigator Group. Basal insulin glargine (HOE 901) versus $\mathrm{NPH}$ insulin in patients with type 1 diabetes on multiple daily insulin regimens. Diabetes Care 2000;23:1137-42.

2. Pieber TR, Eugene-Jolchine I, Derobert E. Efficacy and safety of HOE 901 versus NPH insulin in patients with type 1 diabetes. Diabetes Care 2000;23:15762.

3. Van Dyk J, HOE 901/3003 Study Group. Insulin glargine (HOE901) lowers fasting blood glucose in children with type 1 diabetes mellitus without increasing the risk of hypoglycaemia. J Pediatr Endocrinol Metab 2000;13(Suppl 4):1217.

4. Hershon K, Blevins T, Donley D, Littlejohn C. Lower fasting blood glucose (FBG) and less symptomatic hypoglycemia with QD insulin glargine (LANTUS) compared to BID NPH in subjects with type 1 diabetes. Diabetes. 2001;5O(Suppl 2):A116-A117.

5. Hershon KS, Blevins TC, Mayo CA, Rosskamp R. Once-daily insulin glargine compared with twice-daily NPH insulin in patients with type 1 diabetes. Endocr Pract 2004;10:10-7.

6. Hershon K, Blevins T, Donley D, Littlejohn C. Beneficial effects of insulin glargine compared to NPH in subjects with type 1 diabetes. Diabetologia $2001 ; 44$ (Suppl 1):A15.27.

7. Garg SK, Chase H, Marshall G. Plasma glucose profiles in patients with type 1 diabetes treated with insulin glargine or NPH insulin. Diabetes 2001;50:A435-6.

8. Witthaus E, Stewart J, Bradley C. Treatment satisfaction and psychological wellbeing with insulin glargine compared with NPH in patients with type 1 diabetes. Diabetic Medicine. 2001 Aug 1;18(8):619-25.

9. Roberts A, Bayer T, Munksgaard E, Lang H, Standl E. Efficacy and safety of 6month treatment with insulin detemir in type 1 diabetic patients on a basal/bolus regimen [abstract]. Diabetes 2001;50:A129.

10. Standl E, Lang H, Roberts A. The 12-month efficacy and safety of insulin detemir and NPH insulin in basalbolus therapy for the treatment of type 1 diabetes.

Diabetes Technol Ther 2004; 6: 579-588. 
11. Porcellati F; Rossetti F: Fanelli CG, et al. Glargine vs NPH as basal insulin in intensive treatment of TIDM given lispro at meals: One year comparison. Diabetes. 2002;51(Suppl 2): A53.

12. Porcellati F, Rossetti P, Pampanelli S, Fanelli CG, Torlone E, Scionti L, et al. Better long-term glycaemic control with the basal insulin glargine as compared with NPH in patients with type 1 diabetes mellitus given meal-time lispro insulin. Diabet Med 2004;21:1213-20.

13. Home P, Bartley P, Landin-Olsson M, Russell-Jones D, Hylleberg B, Draeger E. Insulin detemir offers improved glycemic control, less weight gain, and flexible timing of administration compared to NPH insulin. Diabetes 2003; 52 (Suppl. 1): A122.

14. Home P, Bartley P, Russell-Jones D, et al.; Study to Evaluate the Administration of Detemir Insulin Efficacy, Safety and Suitability (STEADINESS) Study Group. Insulin detemir offers improved glycemic control compared with NPH insulin in people with type 1 diabetes: a randomized clinical trial. Diabetes Care. 2004; 27 : 1081-1087.

15. Robertson K, Schönle E, Gucev Z, et al. Benefits of insulin detemir over NPH insulin in children and adolescents with Type 1 diabetes: lower and more predictable fasting plasma glucose and lower risk of nocturnal hypoglycemia [abstract]. Diabetes 2004;53(Suppl 2):A144.

16. Robertson KJ, Schoenle E, Gucev Z, et al. Insulin detemir compared with NPH insulin in children and adolescents with type 1 diabetes. Diabet Med. 2007; 24: 27-34.

17. Pieber TR, Plank J, Goerzer E. Duration of action, pharmacodynamic profile and between-subject variability of insulin detemir in subjects with type 1 diabetes. Diabetes 2004;51(Suppl. 2):A53.

18. Doyle EA, Weinzimer SA, Steffen AT, Ahern JA, Vincent M, Tamborlane WV. A randomized, prospective trial comparing the efficacy of continuous subcutaneous insulin infusion with multiple daily injections using insulin glargine. Diabetes Care. 2004;27(7):1554-8.

19. Kølendorf K, Prasek M, Santeusanio F, et al. Insulin detemir is associated with lower risk of hypoglycaemia compared to NPH insulin in people with type 1 diabetes [abstract]. Diabetologia 2004;47(Suppl 1):913. 
20. Kølendorf K, Ross GP, Pavlic-Renar I, et al. Insulin detemir lowers the risk of hypoglycaemia and provides more consistent plasma glucose levels compared with NPH insulin in Type 1 diabetes. Diabet Med. 2006; 23: 729-735.

21. De Leeuw I, Vague P, Selam JL et al. Insulin detemir used in basal-bolus therapy in people with type 1 diabetes is associated with a lower risk of nocturnal hypoglycaemia and less weight gain over 12 months in comparison to NPH insulin. Diabetes Obes Metab 2005; 7: 73-82.

22. Kudva YC, Basu A, Jenkins GD, et al. Randomized controlled clinical trial of glargine versus ultralente insulin in the treatment of type 1 diabetes. Diabetes Care 2005;28:10-4.

23. Davies MJ, Chatterjee S, Rengarajan T, Lawrence IG, McNally PG. Glargine vs insulatard: efficacy in comparison with insulin aspart in a basal bolus regimen in type 1 diabetes - the Glargine and Aspart Study (GLASS) [abstract]. Diabetologia 2005;48(Suppl 1):A329.

24. Chatterjee S, Jarvis-Kay J, Rengarajan T, Lawrence IG, McNally PG, Davies MJ: Glargine versus NPH insulin: efficacy in comparison with insulin aspart in a basal bolus regimen in type 1 diabetes-the glargine and aspart study (GLASS) a randomised cross-over study. Diabetes Res Clin Pract 2007;77:215-222.

25. Kawamura T, Higashide T, Hirose M, et al. Prospective, randomized, crossover study using insulin glargine and aspart compared with basal-bolus using NPH in Japanese children and adolescents with type 1 diabetes [poster]. Proceedings of the 65th Annual Scientific Sessions; 2005 June 10; San Diego (CA).

26. Mianowska B, Szadkowska A, Czerniawska E, et al. A randomized cross-over trial comparing glargine and NPH insulin in preadolescent type 1 diabetic children. Diabetologia 2006;49(Suppl 1):559.

27. Mianowska B, Szadkowska A, Czerniawska E, Pietrzak I, Bodalski J: [Insulin glargine improves fasting blood glucose levels in prepubertal children with unsatisfactorily controlled type 1 diabetes]. Pediatr Endocrinol Diabetes Metab 2007;13:189-193.

28. Chase HP, Arslanian S, White NH, et al. Insulin glargine (GLAR) vs intermediateacting insulin in adolescents with type 1 diabetes (T1 DM) using multiple daily injection (MDI) therapy. Diabetologia. 2006;49 (Suppl 1):559.

29. Chase HP, Arslanian S, White NH, Tamborlane WV. Insulin glargie versus intermediate-acting insulin as the basal component of multiple daily injection 
regimens for adolescents with type 1 Diabetes Mellitus. J Pediatr. 2008; 153 : 547-553.

30. Bolli G, Songini M, Trovati M, et al. Transfer of patients with type 1 diabetes from NPH insulin to insulin glargine as basal insulin: a multicentre, randomised, parallel- group, open-label study Diabetologia 2006;49(Suppl 1):607.

31. Bolli GB, Songini M, Trovati M, Del Prato S, Ghirlanda G, Cordera R, Trevisan R, Riccardi G, Noacco C. Lower fasting blood glucose, glucose variability and nocturnal hypoglycaemia with glargine vs NPH basal insulin in subjects with Type 1 diabetes. Nutrition, Metabolism \& Cardiovascular Diseases. 2009; 19: 571-579.

32. White $\mathrm{NH}$, Tamborlane W, Usiskin K. Less variability in blood glucose (BG) values with insulin glargine (GLAR) vs intermediate-acting insulin (NPH or Lente) in adolescents with type 1 diabetes. Proceedings of the American Diabetes Association 66th Scientific Sessions; 2006 June 9; Washington (DC).

33. Pesic M, Zivic S, Radenkovic S, Velojic M, Dimic D, Antic S. [Comparison between basal insulin glargine and NPH insulin in patients with diabetes type 1 on conventional intensive insulin therapy] [Serbian]. Vojnosanit Pregl 2007;64:247-52.

34. Pieber TR, Treichel HC, Hompesch B, et al. Comparison of insulin detemir and insulin glargine in subjects with Type 1 diabetes using intensive insulin therapy. Diabet Med 2007; 24: 635-642.

35. Radman M, Jurisic D, Ljutic D, Jerkovic R, Kovacic N, Hozo IS. Assessing glycemia in type 1 diabetic patients using a microdialysis system for continuous glucose monitoring. Ann Saudi Med 2007; 27: 166-170.

36. Philippo $\mathrm{H}$, Novo Nordisk. Efficacy and safety of insulin detemir in type 1 diabetes. 2007. www.clinicaltrials.gov/ct2/show/study/NCT00595374.

37. Trial NN304-1689. Clinical Trial Report. Available: http://novonordisk-trials.com/ website/pdf/registry/bin_20 090 818-082 619-197.pdf.

38. Trial NN304-1595. Clinical Trial Report. Available: http://www.novonordisktrials.com/Website/pdf/registry/nn3041595.pdf.

39. Bartley PC, Bogoev M, Larsen J, Philotheou A. Long-term efficacy and safety of insulin detemir compared to Neutral Protamine Hagedorn insulin in patients with Type 1 diabetes using a treat-to-target basal-bolus regimen with insulin aspart at meals: a 2-year, randomized, controlled trial. Diabet Med. 2008; 25: 442-449. 
40. Trial NN304 1604. Integrated Clinical Trial Report. Disponível em: http://novonordisk trials.com/website/pdf/registry/bin_20 070614125633 724.pdf.

41. Ashwell SG, Bradley C, Stephens JW, Witthaus E, Home PD. Treatment satisfaction and quality of life with insulin glargine plus insulin lispro compared with NPH insulin plus unmodified human insulin in individuals with type 1 diabetes. Diabetes Care. 2008 Jun 1;31(6):1112-7.

42. Ashwell SG, Amiel SA, Bilous RW, Dashora U, Heller SR, Hepburn DA, Shutler SD, Stephens JW, Home PD: Improved glycaemic control with insulin glargine plus insulin lispro: a multicentre, randomized, cross-over trial in people with Type 1 diabetes. Diabet Med 2006;23:285-292.

43. White NH, Chase HP, Arslanian S, Tamborlane WV. Comparison of glycemic variability associated with insulin glargine and intermediate-acting insulin when used as the basal component of multiple daily injections for adolescents with type 1 diabetes. Diabetes Care. 2009 Mar 1;32(3):387-93.

44. Zachariah S, Sheldon B, Shojaee-Moradie F, Jackson NC, Backhouse K, Johnsen $\mathrm{S}$, et al. Insulin detemir reduces weight gain as a result of reduced food intake in patients with type 1 diabetes. Diabetes Care 2011;34:1487-91.

45. Mathiesen ER, Hod M, Ivanisevic M, Duran Garcia S, Brøndsted L, Jovanovic L, et al. Maternal efficacy and safety outcomes in a randomized, controlled trial comparing insulin detemir with NPH insulin in 310 pregnant women with type 1 diabetes. Diabetes Care 2012;35:2012-7. 